\title{
Cerebral small vessel disease : endothelial progenitor cells and markers of vascular inflammation
}

Citation for published version (APA):

Rouhl, R. P. W. (2012). Cerebral small vessel disease : endothelial progenitor cells and markers of vascular inflammation. [Doctoral Thesis, Maastricht University]. Datawyse / Universitaire Pers Maastricht. https://doi.org/10.26481/dis.20120302rr

Document status and date:

Published: 01/01/2012

DOI:

10.26481/dis.20120302rr

Document Version:

Publisher's PDF, also known as Version of record

\section{Please check the document version of this publication:}

- A submitted manuscript is the version of the article upon submission and before peer-review. There can be important differences between the submitted version and the official published version of record.

People interested in the research are advised to contact the author for the final version of the publication, or visit the DOI to the publisher's website.

- The final author version and the galley proof are versions of the publication after peer review.

- The final published version features the final layout of the paper including the volume, issue and page numbers.

Link to publication

\footnotetext{
General rights rights.

- You may freely distribute the URL identifying the publication in the public portal. please follow below link for the End User Agreement:

www.umlib.nl/taverne-license

Take down policy

If you believe that this document breaches copyright please contact us at:

repository@maastrichtuniversity.nl

providing details and we will investigate your claim.
}

Copyright and moral rights for the publications made accessible in the public portal are retained by the authors and/or other copyright owners and it is a condition of accessing publications that users recognise and abide by the legal requirements associated with these

- Users may download and print one copy of any publication from the public portal for the purpose of private study or research.

- You may not further distribute the material or use it for any profit-making activity or commercial gain

If the publication is distributed under the terms of Article $25 \mathrm{fa}$ of the Dutch Copyright Act, indicated by the "Taverne" license above, 


\title{
Cerebral Small Vessel Disease
}

\author{
Endothelial Progenitor Cells and \\ Markers of Vascular Inflammation
}


(C) Rob Rouhl, Maastricht 2012

Layout: Tiny Wouters

Cover design: Martijn Bok

Production: Datawyse/Universitaire Pers Maastricht

ISBN 9789461591234

The printing of this thesis was financially supported by the Dutch Heart Foundation and Maastricht University Medical Centre. Further support was received from Boehringer Ingelheim, UCB Pharma BV, Novartis, and GlaxoSmithKline. 


\title{
Cerebral Small Vessel Disease
}

\author{
Endothelial Progenitor Cells and \\ Markers of Vascular Inflammation
}

\begin{abstract}
PROEFSCHRIFT
ter verkrijging van de graad van doctor aan de Universiteit Maastricht, op gezag van de Rector Magnificus, Prof. Mr. G.P.M.F. Mols

volgens het besluit van het College van Decanen,

in het openbaar te verdedigen

op vrijdag 2 maart 2012 om 10.00 uur
\end{abstract}

door

Rob Peter Willem Rouhl

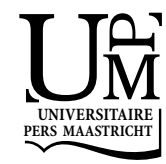




\section{Promotores:}

Prof. dr. J. Lodder

Prof. dr. J.W. Cohen Tervaert

Prof. dr. R.J. van Oostenbrugge

\section{Beoordelingscommissie:}

Prof. dr. H. ten Cate (voorzitter)

Prof. dr. W.A. Buurman

Prof. dr. J. de Mey

Prof. dr. A.J. Rabelink, Universiteit Leiden

Prof. dr. J.M. Wardlaw, University of Edinburgh, UK

The research described in this thesis was supported by a grant of the Dutch Heart Foundation (DHF-2005B022)

Financial support by the Dutch Heart Foundation for the publication of this thesis is gratefully acknowledged. 


\section{Contents}

$\begin{array}{ll}\text { Abbreviations } & 7\end{array}$

Chapter 1 General introduction 9

Chapter 2 Virchow-Robin spaces relate to cerebral small vessel disease 23 severity

Chapter 3 Auto-antibodies against oxidized LDL in cerebral small vessel disease

Chapter 4 Vascular inflammation in cerebral small vessel disease

Chapter 5 Endothelial progenitor cells in cerebrovascular disease

Chapter 6 Haptoglobin phenotype may alter endothelial progenitor cell cluster formation in cerebral small vessel disease

Chapter 7 Angiogenic T-cells and putative endothelial progenitor cells in hypertension related cerebral small vessel disease

Chapter 8 General discussion

Summary

Samenvatting

Dankwoord

List of publications

Curriculum Vitae 



\section{Abbreviations}

\begin{tabular}{|c|c|}
\hline ACE & Angiotensin I-Converting Enzyme \\
\hline ANCA & Antineutrophil Cytoplasmic Antibodies \\
\hline BBB & Blood-Brain Barrier \\
\hline BDNF & Brain Derived Neurotrophic Factor \\
\hline BG-VRs & Virchow Robin spaces at the level of the Basal Ganglia \\
\hline BMVEC & Brain Microvascular Endothelial Cells \\
\hline CAD & Coronary Artery Disease \\
\hline $\mathrm{Cl}$ & Confidence Interval \\
\hline CRP & C-reactive protein \\
\hline CSO-VRs & Virchow Robin spaces at the level of the centrum semiovale \\
\hline CSVD & Cerebral Small Vessel Disease \\
\hline CT & Computed Tomography \\
\hline ECG & Electrocardiography \\
\hline ELISA & Enzyme Linked Immunosorbent Assay \\
\hline EMP & Endothelial Microparticle \\
\hline eNOS & Endothelial Nitric Oxide Synthetase \\
\hline EPC & Endothelial Progenitor Cells \\
\hline eVRs & Enlarged Virchow Robin spaces \\
\hline FLAIR & Fluid Attenuated Inversion Recovery \\
\hline HDL & High Density Lipoprotein \\
\hline $\mathrm{HOCl}$ & Hypochlorite \\
\hline hsCRP & High sensitivity C-reactive protein \\
\hline IgG & Immunoglobulin G \\
\hline $\lg M$ & Immunoglobulin M \\
\hline IL & Interleukin \\
\hline KDR & Kinase Insert Domain Receptor \\
\hline LDL & Low Density Lipoprotein \\
\hline L-VRs & Linear Virchow Robin spaces at the level of the centrum semiovale \\
\hline MCP-1 & Monocyte Chemotactic Protein-1 \\
\hline MDA & Malondialdehyde \\
\hline MMP & Matrix Metalloproteinase \\
\hline $\mathrm{MR}(\mathrm{I})$ & Magnetic Resonance (Imaging) \\
\hline NF & Nuclear Factor \\
\hline NIHSS & National Institute of Health Stroke Scale \\
\hline OD & Optical Density \\
\hline OR & Odds Ratio \\
\hline oxLDL & Oxidized Low Density Lipoprotein \\
\hline PC & Progenitor Cells \\
\hline PECAM & Platelet Endothelial Cellular Adhesion Molecule \\
\hline
\end{tabular}


PET

SIL

SPECT

SPSS

TERT

UEA

VEGF

VEGFR-2

VRs

WML
Positron Emission Tomography

Silent Ischemic Lesions

Single Photon-Emission Computed Tomography

Statistical Package for the Social Sciences

Telomerase Reverse Transcriptase

Ulex europaeus lectin

Vascular Endothelial Growth Factor

Vascular Endothelial Growth Factor Receptor 2

Virchow Robin spaces

White Matter Lesions 


\section{Chapter 1}

\section{General introduction}

Parts of this Chapter were adapted from:

Rouhl RPW, van Oostenbrugge RJ, Lodder J. White Matter Lesions: From Present to Future. In: Westland TB, Calton RN, eds. Handbook on White Matter: Structure, Function, and Changes. New York: Nova Publishers; 2009:17-28. 
10 Chapter 1 


\section{Cerebral small vessel disease}

Stroke is the third leading cause of death and the first leading cause of long term disability worldwide. There are several different types of stroke: around $20 \%$ of patients have a hemorrhagic stroke, whereas $80 \%$ suffer an ischemic event. Again, in the ischemic subgroup, several different etiological subgroups can be recognized, like cardio-embolic stroke (about $25 \%$ of ischemic strokes), large vessel atherosclerotic stroke (about $40 \%$ ), stroke by rare causes (around 5\%) and lacunar stroke (about 25\%). Lacunar stroke is caused by a lacunar infarct, which consists of a small ischemic lesion in the region of the penetrating arteries deeply in the brain. Unlike previously thought, lacunar stroke is not a more benign stroke subtype than other stroke types with regard to long term mortality or disability, ${ }^{1,2}$ probably because of the nature of its underlying vascular pathology.

The underlying pathology causing lacunar stroke, cerebral small vessel disease (CSVD), is a disease which affects the small penetrating arterioles in the brain. Up till today, studies mainly emphasize the epidemiological and clinical associations of CSVD and its accompanying lesions, like lacunar infarcts and cerebral white matter lesions (WML). However, the cause of CSVD, and therefore any therapeutic or preventive regimen, remains elusive. In this chapter, an introduction on the background of the subject of this thesis is presented with a focus on the present hypothesis concerning the pathophysiological development of CSVD.

\section{Is cerebral small vessel disease the cause of cerebral white matter lesions and lacunar infarcts?}

The exact pathogenesis of lacunar infarcts and WML remains unclear. However, epidemiological data suggest a vascular pathophysiology. For example on imaging, WML relate to lacunar infarcts, and most strongly to multiple lacunar infarcts, ${ }^{3}$ whereas both WML as well as lacunar infarcts relate to vascular risk factors like increasing age $\mathrm{e}^{4-6}$ and hypertension. ${ }^{3}$ Clinically, WML and lacunar infarcts relate to (recurrent) ischemic stroke, ${ }^{7-9}$ cognitive disturbance (mainly in the area of executive functioning, ${ }^{10-14}$ cognitive flexibility, ${ }^{15}$ and speed of information processing ${ }^{14}$ ), cognitive decline ${ }^{4,16}$ and frank dementia, ${ }^{17}$ gait disturbances, ${ }^{18}$ and urinary problems. ${ }^{19}$ In lacunar stroke patients, WML relate to a worse prognosis (with regard to morbidity, stroke recurrence, and mortality), ${ }^{7}$ also on the long term. ${ }^{20}$ Furthermore, the progression of WML and lacunar lesions relates to the presence of vascular risk factors like hypertension and previous vascular disease. ${ }^{21}$ All these epidemiological data strongly suggest an on-going (vascular) pathology in the brain. 
In pathological studies, there is evidence that CSVD causes WML and lacunar infarcts. However, there are different pathological processes in the cerebral small vessels which could cause lacunar infarcts, WML or both. Fisher meticulously described the types of small vessel abnormalities which occur proximal to a lacunar infarct: one he called micro-atheromatosis $^{22}$ (which represents atherosclerosis on an arteriolar level, mostly in arterioles of more than 200 micrometer in diameter, and relates to large, single lacunar infarcts) ${ }^{23}$ and the other one was characterized by segmental wall disorganization ${ }^{24}$ (or fibrinoid necrosis in the acute stage and lipohyalinosis in a healed stage; later called complex cerebral small vessel disease, ${ }^{25}$ which occurs in arterioles of a diameter smaller than 200 micrometer, and relates to multiple small lacunar infarcts). ${ }^{23}$ Both lead to micro-vascular occlusion, as can be demonstrated by imaging. ${ }^{26}$ Fisher suggested that hypertension was the major risk factor for both these conditions. $^{27,28}$

Extensive, diffuse WML, however, relate to a third microvascular abnormality ${ }^{1}$ : arteriolosclerosis. $^{29-32}$ Arteriolosclerosis consists of hyaline wall thickening with consequent narrowing of the arteriolar lumen, and a poor response to changes in cerebral blood flow. ${ }^{33,34}$ The presence of arteriolosclerosis in brain arterioles is associated with age, hypertension, and diabetes, ${ }^{34,35}$ also in neurologically healthy individuals. ${ }^{35}$ WML patients more often have hypertension than cerebrovascular patients without WML; however, hypertension is not a conditio sine qua non for the development of WML as the vascular abnormalities can also be found in brains of nonhypertensives. ${ }^{36}$ On the other hand, the risk factor profile (mainly the association with hypertension) is similar in patients with multiple lacunar infarcts (complex small vessel disease) and WML patients (arteriolosclerosis). ${ }^{37}$ However, whether arteriolosclerosis is a preliminary stage of complex small vessel disease (or the other way around) remains to be elucidated. ${ }^{25}$

Cerebral lesions like WML and lacunar infarcts could also be caused by other diseases than this aforementioned CSVD. Lammie et al. e.g. suggested from the pathological appearance of some lacunar infarcts (which he called incomplete), that also transient processes like temporary reduction of blood flow, multiple emboli, or small vessel spasms could lead to multiple lacunar infarcts, ${ }^{38}$ as he could not demonstrate any arteriolar abnormality in these cases. Others also argue, especially in case of multiple lacunar infarcts, for an embolic source (which may be the heart or a proximal larger artery).$^{39}$ However, when all patients with potential embolic sources are excluded from these studies, there are still patients with multiple lacunar infarcts; even more strikingly, lacunar stroke is much less strongly related to a cardiac embolic source than other stroke subtypes. ${ }^{40}$ Therefore, it is unlikely that an embolic source accounts for all

\footnotetext{
${ }^{1}$ Note that punctuate WML (in contrast to the abovementioned diffuse or large confluent areas of WML) are pathologically very heterogeneous. These punctuate foci can represent myelin pallor, local demyelination, as well as areas of gliosis and ischemia. The underlying vascular pathology is therefore equally heterogeneous and sometimes even absent.
} 
multiple lacunar infarct patient in these series. CSVD (with micro-atheromatosis, complex cerebral small vessel disease, and arteriolosclerosis as pathological hallmarks) therefore remains the most probable cause of lacunar infarcts and WML.

\section{Other possible manifestations of cerebral small vessel disease}

Since the use of brain imaging, especially with the use of MRI, other possibly CSVD related abnormalities have been noted. Of these, brain microbleeds have already been accepted as a manifestation of CSVD. Though there are no studies on the underlying vascular pathology accompanying these lesions, epidemiological studies suggest a common pathogenesis with WML and lacunar infarcts because these deeply located brain microbleeds co-occur with WML and lacunar infarcts. ${ }^{41,42}$ Similar to WML and lacunar infarcts brain microbleeds are blood pressure related: with increased day and night time blood pressure levels brain microbleed numbers are increased as well. ${ }^{43,44} \mathrm{~A}$ more debated characteristic of CSVD is the enlargement of perivascular spaces, or Virchow Robin spaces (VRs). These spaces surround the penetrating arteries and arterioles in the brain. Enlargement of VRs has been attributed to vascular ectasia and tortuosity, increased vessel wall permeability, a decrease in vascular compliance, ischemic perivascular tissue loss, to an ex vacuo phenomenon in cortical atrophy, and to inflammatory activity. ${ }^{32,45-47}$ Clinically, enlarged VRs relate to $\mathrm{WML},{ }^{32,46}$ and to hypertension, ${ }^{48}$ which points to a possible relation between VRs and CSVD.

\section{Outline of the Thesis - Chapter 2}

In order to consolidate the epidemiologic relation between enlarged VRs and established manifestations of CSVD like multiple lacunar infarcts and WML, we performed a study in a group of first-ever lacunar stroke patients. A co-occurrence of enlarged VRs and multiple lacunar infarcts and WML would indicate a common pathophysiology of these abnormalities: CSVD.

\section{Pathogenesis of cerebral small vessel disease: the blood-brain barrier, endothelial activation and dysfunction}

The blood-brain barrier (BBB) consists of brain microvascular endothelial cells (BMVEC) and the surrounding astrocytes, pericytes, neurons, and extracellular matrix. ${ }^{49,50}$ The interplay among these cells and the extracellular matrix is complex and maintained by all of its components. ${ }^{49,50}$ The BMVEC are linked to each other by tight junctions, adherent junctions and junctional adhesion molecules; of these, the tight junctions are most important in the endothelial resistance to the plasma constituents. ${ }^{49,50}$ Adhesion of leukocytes to BMVEC, catalysed by the expression of adhesion molecules, leads to 
loss of the integrity of the tight junctions. ${ }^{49}$ Several components of the tight junctions (e.g. occludin, claudins, and zonula occludens-1) are also vulnerable to products and mediators of inflammation, like matrix metalloproteinases and MCP-1. ${ }^{50}$ When the tight junctions lose their integrity, the BBB itself loses its integrity; and when the BBB fails and plasma components enter the brain parenchyma, neurotoxic products that compromise synaptic and neuronal functions are released..$^{50}$

Therefore, one of the major theories at this moment for the development of arteriolosclerosis and complex small vessel disease is that an increased permeability of the $\mathrm{BBB}^{51,52}$ leads to white matter damage and lacunar stroke. This is furthermore suggested by:

- oedema related gliosis in WML and its similarity to the brain edema which is caused by BBB disruption in animal models ${ }^{53}$

- the relation of cerebral oedema formation with factors which increase BBB permeability, like liver failure, renal failure, pancreatitis, and alcoholism. All these factors also relate to lacunar infarcts ${ }^{36}$

- changes in BBB integrity which have been demonstrated using MRI with Gadolinium contrast enhancement in lacunar stroke patients (these changes are only present to a lesser extent in patients with other types of stroke $)^{54,55}$ in patients with $\mathrm{WML}^{56}$ as well as in normal appearing white matter of patients with lacunar stroke with WML as compared to lacunar stroke patients without $\mathrm{WML}^{57}$

- leakage of specific proteins from blood to cerebrospinal fluid, which is only possible in case of a defective BBB, in patients with recurrent lacunar stroke ${ }^{58}$

- leakage of plasma proteins into the perivascular space, where they are phagocytised by astrocytes in brain regions with $\mathrm{WML}^{32}$

Of note, the components of the BBB are different for the arterioles and the capillaries. The arterioles also have muscular layers and are surrounded by a perivascular spaces, whereas the capillaries lack both. ${ }^{59}$ Thus, in order to disrupt the BBB on an arteriolar level, more barriers have to be taken as compared to the capillary level. ${ }^{59}$ Though, enlargement of the perivascular spaces (periarteriolar as well as perivenular) relates to permeabilization of the BBB. ${ }^{47}$

In turn, the defective BBB is most likely caused by dysfunction of the endothelial cells of the arterioles and smaller blood vessels in the brain. As described above, expression of adhesion molecules (like selectins or cellular adhesion molecules (CAMs)), which is a characteristic of endothelial activation and dysfunction, ${ }^{60}$ may eventually lead to BBB leakage. The adhesion molecules are expressed on the surface of endothelial cells, but on increasing activation and dysfunction upregulated and also shed into the circulation in their soluble (s) form, and thus they can be measured in peripheral blood. Several authors demonstrated that markers of endothelial activation/dysfunction, like Eselectin, $^{61}$ ICAM, $^{61-63}$ P-selectin, ${ }^{64}$ VCAM, $^{64}$ thrombomodulin ${ }^{65}$ and von Willebrand factor $^{66}$ are present in peripheral blood of subjects with WML. Also, patients with WML progression have higher levels of markers of endothelial activation/dysfunction (ICAM). ${ }^{67}$ Furthermore, there are also relations between certain gene polymorphisms 
which are involved in endothelial function on one hand and WML on the other. ${ }^{68}$ However, the cause of the endothelial activation/dysfunction remains unclear.

\section{Vascular inflammation}

The increased expression of adhesion molecules by endothelial cells enables leukocyte-endothelial cell interactions. ${ }^{69}$ As a result of these leukocyte-endothelial interactions, both endothelial cells and leukocytes (e.g. monocytes) become increasingly activated. ${ }^{70}$ Activated monocytes/macrophages produce neopterin (only when activated by T-lymphocytes) as well as cytokines which induce liver cells to produce C-reactive protein (CRP). ${ }^{71}$ Both these inflammatory markers relate to vascular events, ${ }^{72}$ and higher CRP levels also relate to $\mathrm{WML}^{73,74}$ as well as to the progression of these lesions over time, ${ }^{74}$ though not in all studies. ${ }^{75}$ Furthermore, the gene of the cytokine IL-6, which induces CRP production in the liver, has polymorphisms of which some are related to WML. ${ }^{76}$ However, studies concerning known polymorphisms in the CRP-gene could not demonstrate a relation between these polymorphisms and WML. $^{76,77}$ Neopterin may itself induce endothelial activation and eventually endothelial dysfunction, with increased expression of adhesion molecules as a consequence. $^{78}$ Thus, the cellular immune system could instigate as well as propagate the development of endothelial dysfunction in the brain, leading to BBB breakdown and CSVD.

The humoral immune system could play a role as well. Similar to its established role in atherosclerosis, oxidized Low Density Lipoprotein (oxLDL) could act as a proinflammatory compound. ${ }^{79}$ It induces endothelial dysfunction and induction of autoantibodies. ${ }^{80,81}$ With respect to the antibodies against oxLDL, those of the IgM-isotype are primarily naturally occurring antibodies, considered to protect from vascular disease, ${ }^{82,83}$ whereas those of the IgG-isotype are mostly induced (not-naturally occurring) antibodies and are considered harmful, ${ }^{84,85}$ though data are conflicting regarding these roles. ${ }^{86}$ Next to their involvement in atherosclerosis, anti-oxLDL antibodies could also play a role in CSVD.

\section{Outline of the Thesis - Chapter 3 and 4}

In chapter 3, our aim was to demonstrate a relation between the presence of higher amounts of IgG-anti-oxLDL antibodies and lower levels of IgM-anti-oxLDL antibodies on one hand and the occurrence of WML and multiple asymptomatic lacunar infarcts on the other. We studied two patient groups, one consisting of patients with a first-ever lacunar stroke, and the other of patients with essential hypertension. Finding the aforementioned relation suggests involvement of the humoral immune system in CSVD. Similarly, in chapter 4, our aim was to demonstrate a relation between higher levels of markers of endothelial activation as well as markers of monocyte activation (neopterin) with radiological CSVD manifestations. We studied the same patient 
groups as in Chapter 3. A significant relation among neopterin, markers of endothelial dysfunction and radiological CSVD manifestations would suggest a role for the cellular immune system (monocytes and T-lymphocytes) and endothelial activation in CSVD.

\section{New insights into endothelial biology: endothelial progenitor cells}

Because endothelial cell activation and dysfunction are considered to be a key factor in the development of CSVD, new insights into endothelial biology, such as the role played by endothelial progenitor cells (EPC) in the regulation of endothelial cell activation and dysfunction, might be important.

EPC are immature endothelial cells which circulate in peripheral blood. EPC are presumed to be involved in the repair of damaged endothelium, because EPC offspring is present in restored endothelium. ${ }^{87-90}$ Circulating numbers of EPC may be lower when there is a higher consumption of EPC for the restoration of endothelial damage. Circulating numbers of EPC may reflect endothelial damage ${ }^{91}$ Clinically, EPC numbers are found to be lower in patients with atherosclerotic risk factors, ${ }^{92}$ amongst others in patients with essential hypertension. ${ }^{93-96}$ In these cases, EPC numbers probably are lower as a consequence of a higher consumption, and run relatively short on restoring the damaged endothelium with consequent atherosclerosis and cardiovascular events. Furthermore, EPC numbers relate to cardiovascular prognosis: in patients with coronary artery disease, EPC numbers at baseline are lower in patients who will suffer a cardiovascular event than in event-free patients (after at least ten months of follow up). ${ }^{97,98}$ This association between lower EPC numbers and worse cardiovascular prognosis remained significant after correction for other known cardiovascular risk factors. Therefore, EPC numbers may constitute a new risk marker for future cardiovascular events.

Neurovascular research on EPC is limited until now. Studies show that: 1) EPC numbers were lower in stroke patients (in the acute phase as well as later) than in healthy controls, ${ }^{99,100}$ 2) EPC numbers were higher in patients with cardioembolic stroke than in patients with large or small vessel stroke, ${ }^{100}$ 3) EPC numbers were higher in patients with good outcome than in those patients with a bad outcome, ${ }^{101}$ and 4) EPC numbers increase in the first 7 days after a stroke. ${ }^{102,103}$ All these findings point to a possible role of EPC in the acute pathophysiological process after ischemic stroke. In general, higher EPC numbers seem beneficial; however, these results do not allow conclusions with regard to regulation of EPC function, because the studies were observational in character.

\section{Outline of the Thesis - Chapter 5}

In Chapter 5, our aim was to provide an overview on the potentials and pitfalls of the applications of EPC in general, and for stroke in particular. We provided an overview of 
EPC biology, EPC measurement, use of EPC as a risk marker, and the possible use of EPC as a therapeutic agent.

In CSVD, data on EPC are scarce. Next to the abovementioned associations regarding EPC, EPC also play a role in the functional properties of the endothelial cells, as evidenced by the relation between EPC number and endothelial function (flowmediated arterial dilatation). ${ }^{92}$ Therefore, EPC could play a role in restoring the presumed endothelial activation and dysfunction which underlies the development of CSVD. Although regulating factors for EPC function remain elusive, we would like to suggest two possible candidates for EPC regulation in CSVD. The first is the haptoglobin phenotype. Haptoglobin is an acute phase protein and has three different phenotypes. Earlier, we demonstrated that the haptoglobin phenotype 2-2 is underrepresented in lacunar stroke patients with asymptomatic lacunar infarcts and WML. ${ }^{104}$ Furthermore, haptoglobin 2-2 relates to angiogenic potential. ${ }^{105}$ Therefore, the haptoglobin phenotype could be related to the EPC response. The second is the angiogenic T-cell. These T-cells express the receptor for stromal derived factor 1 (CD184) as well as the platelet endothelial cell adhesion molecule (PECAM; CD31). ${ }^{106}$ Furthermore, these cells promote the formation of new blood vessels and endothelial repair by directly stimulating the function of EPC. ${ }^{106}$ Both lower numbers of EPC as well as lower numbers of angiogenic T-cells relate to a higher cardiovascular risk, ${ }^{106}$ suggesting a combined role for EPC and angiogenic T-cells in vascular disease.

\section{Outline of the Thesis - Chapter 6 and 7}

In Chapter 6, our aim was to demonstrate a relation between EPC number and vitality and multiple lacunar infarcts and WML in patients with a first-ever lacunar stroke and healthy controls. We also looked for possible regulating factors for EPC function in patient serum and studied the effect of different haptoglobin phenotypes on EPC. In Chapter 7, our aim was to demonstrate a relation between EPC number and vitality and multiple lacunar infarcts and WML in another patient population, essentially hypertensive patients. In this study, we also determined whether angiogenic T-cells related to the presence of CSVD.

\section{Outline of the Thesis - Chapter 8}

In Chapter 8, a discussion regarding the findings of this thesis is presented, also considering the strengths and weaknesses of the studies. Directions for future research are pointed out. 


\section{References}

1. Norrving B. Lacunar infarcts: no black holes in the brain are benign. Pract Neurol. 2008;8:222-228

2. Sacco S, Marini C, Totaro R, Russo T, Cerone D, Carolei A. A population-based study of the incidence and prognosis of lacunar stroke. Neurology. 2006;66:1335-1338

3. Boiten J, Lodder J, Kessels F. Two clinically distinct lacunar infarct entities? A hypothesis. Stroke. 1993;24:652-656

4. van Dijk EJ, Prins ND, Vrooman HA, Hofman A, Koudstaal PJ, Breteler MM. Progression of cerebral small vessel disease in relation to risk factors and cognitive consequences: Rotterdam Scan study. Stroke. 2008;39:2712-2719

5. Wiszniewska M, Devuyst G, Bogousslavsky J, Ghika J, van Melle G. What is the significance of leukoaraiosis in patients with acute ischemic stroke? Arch Neurol. 2000;57:967-973

6. de Leeuw FE, de Groot JC, Achten E, Oudkerk M, Ramos LM, Heijboer R, Hofman A, Jolles J, van Gijn J, Breteler MM. Prevalence of cerebral white matter lesions in elderly people: a population based magnetic resonance imaging study. The Rotterdam Scan Study. J Neurol Neurosurg Psychiatry. 2001;70:9-14

7. de Jong G, Kessels F, Lodder J. Two types of lacunar infarcts: further arguments from a study on prognosis. Stroke. 2002;33:2072-2076

8. Vermeer SE, Hollander M, van Dijk EJ, Hofman A, Koudstaal PJ, Breteler MM. Silent brain infarcts and white matter lesions increase stroke risk in the general population: the Rotterdam Scan Study. Stroke. 2003;34:1126-1129

9. Kuller LH, Longstreth WT, Jr., Arnold AM, Bernick C, Bryan RN, Beauchamp NJ, Jr. White matter hyperintensity on cranial magnetic resonance imaging: a predictor of stroke. Stroke. 2004;35: $1821-1825$

10. Reed BR, Eberling JL, Mungas D, Weiner M, Kramer JH, Jagust WJ. Effects of white matter lesions and lacunes on cortical function. Arch Neurol. 2004;61:1545-1550

11. Wen HM, Mok VC, Fan YH, Lam WW, Tang WK, Wong A, Huang RX, Wong KS. Effect of white matter changes on cognitive impairment in patients with lacunar infarcts. Stroke. 2004;35:1826-1830

12. Tullberg M, Fletcher E, DeCarli C, Mungas D, Reed BR, Harvey DJ, Weiner MW, Chui HC, Jagust WJ. White matter lesions impair frontal lobe function regardless of their location. Neurology. 2004;63: 246-253

13. Carey CL, Kramer JH, Josephson SA, Mungas D, Reed BR, Schuff N, Weiner MW, Chui HC. Subcortical lacunes are associated with executive dysfunction in cognitively normal elderly. Stroke. 2008;39: 397-402

14. Prins ND, van Dijk EJ, den Heijer T, Vermeer SE, Jolles J, Koudstaal PJ, Hofman A, Breteler MM. Cerebral small-vessel disease and decline in information processing speed, executive function and memory. Brain. 2005;128:2034-2041

15. Wright CB, Festa JR, Paik MC, Schmiedigen A, Brown TR, Yoshita M, DeCarli C, Sacco R, Stern Y. White matter hyperintensities and subclinical infarction: associations with psychomotor speed and cognitive flexibility. Stroke. 2008;39:800-805

16. Garde E, Lykke Mortensen E, Rostrup E, Paulson OB. Decline in intelligence is associated with progression in white matter hyperintensity volume. J Neurol Neurosurg Psychiatry. 2005;76:1289-1291

17. Prins ND, van Dijk EJ, den Heijer T, Vermeer SE, Koudstaal PJ, Oudkerk M, Hofman A, Breteler MM. Cerebral white matter lesions and the risk of dementia. Arch Neurol. 2004;61:1531-1534

18. Baezner H, Blahak C, Poggesi A, Pantoni L, Inzitari D, Chabriat H, Erkinjuntti T, Fazekas F, Ferro JM, Langhorne P, O'Brien J, Scheltens P, Visser MC, Wahlund LO, Waldemar G, Wallin A, Hennerici MG. Association of gait and balance disorders with age-related white matter changes: the LADIS study. Neurology. 2008;70:935-942

19. Poggesi A, Pracucci G, Chabriat H, Erkinjuntti T, Fazekas F, Verdelho A, Hennerici M, Langhorne $P$, O'Brien J, Scheltens P, Visser MC, Crisby M, Waldemar G, Wallin A, Inzitari D, Pantoni L. Urinary Complaints in Nondisabled Elderly People with Age-Related White Matter Changes: The Leukoaraiosis And DISability (LADIS) Study. J Am Geriatr Soc. 2008;56:1638-1643

20. Staals J, van Raak L, Hilton A, Lodder J. Differences in Long-Term Survival in Two Lacunar Stroke Types: A 15-Year Follow-Up Study in 782 Cerebral Infarct Patients. Cerebrovasc Dis. 2007;25:26-31 
21. Gouw AA, van der Flier WM, Fazekas F, van Straaten EC, Pantoni L, Poggesi A, Inzitari D, Erkinjuntti T, Wahlund LO, Waldemar G, Schmidt R, Scheltens P, Barkhof F. Progression of white matter hyperintensities and incidence of new lacunes over a 3-year period: the Leukoaraiosis and Disability study. Stroke. 2008;39:1414-1420

22. Fisher CM. Capsular infarcts: the underlying vascular lesions. Arch Neurol. 1979;36:65-73

23. Fisher CM. Lacunar strokes and infarcts: a review. Neurology. 1982;32:871-876

24. Fisher CM. The arterial lesions underlying lacunes. Acta Neuropathol. 1968;12:1-15

25. Lammie G. Pathology of lacunar infarction. In: Donnan G, Norrving B, Bamford J, Bogousslavsky J, eds. Subcortical Stroke. Oxford: Oxford University Press; 2002:37-46.

26. Wardlaw JM, Dennis MS, Warlow CP, Sandercock PA. Imaging appearance of the symptomatic perforating artery in patients with lacunar infarction: occlusion or other vascular pathology? Ann Neurol. 2001;50:208-215

27. Fisher CM. Lacunes: Small, Deep Cerebral Infarcts. Neurology. 1965;15:774-784

28. Fisher CM. Commentary on Subcortical Strokes. In: Donnan G, Norrving B, Bamford J, Bogousslavsky J, eds. Subcortical Stroke. Oxford: Oxford University Press; 2002:17-25.

29. van Swieten JC, van den Hout JH, van Ketel BA, Hijdra A, Wokke JH, van Gijn J. Periventricular lesions in the white matter on magnetic resonance imaging in the elderly. A morphometric correlation with arteriolosclerosis and dilated perivascular spaces. Brain. 1991;114 ( Pt 2):761-774

30. Ward NS, Brown MM. Leukoaraiosis. In: Donnan G, Norrving B, Bamford J, Bogousslavsky J, eds. Subcortical Stroke. Oxford: Oxford University Press; 2002:47-66.

31. Huang Y, Zhang W, Lin L, Feng J, Zhao X, Guo W, Wei W. Could changes in arterioles impede the perivascular drainage of interstitial fluid from the cerebral white matter in leukoaraiosis? Neuropathol Appl Neurobiol. 2009

32. Fernando MS, Simpson JE, Matthews F, Brayne C, Lewis CE, Barber R, Kalaria RN, Forster G, Esteves F, Wharton SB, Shaw PJ, O'Brien JT, Ince PG. White matter lesions in an unselected cohort of the elderly: molecular pathology suggests origin from chronic hypoperfusion injury. Stroke. 2006;37:1391-1398

33. Tomura N, Sasaki K, Kidani H, Nishii T, Yasuda K, Ishiyama K, Otani T, Sakuma I, Takahashi S, Watarai J, Yanagisawa T, Mizoi K. Reduced perfusion reserve in Leukoaraiosis demonstrated using acetazolamide challenge 123I-IMP SPECT. J Comput Assist Tomogr. 2007;31:884-887

34. Lammie GA. Pathology of small vessel stroke. Br Med Bull. 2000;56:296-306

35. Furuta A, Ishii N, Nishihara Y, Horie A. Medullary arteries in aging and dementia. Stroke. 1991;22: 442-446

36. Lammie GA, Brannan F, Slattery J, Warlow C. Nonhypertensive cerebral small-vessel disease. An autopsy study. Stroke. 1997; 28:2222-2229

37. Khan U, Porteous L, Hassan A, Markus HS. Risk factor profile of cerebral small vessel disease and its subtypes. J Neurol Neurosurg Psychiatry. 2007;78:702-706

38. Lammie GA, Brannan F, Wardlaw JM. Incomplete lacunar infarction (Type lb lacunes). Acta Neuropathol. 1998;96:163-171

39. Millikan CH. About Lacunes. In: Donnan G, Norrving B, Bamford J, Bogousslavsky J, eds. Subcortical Stroke. Oxford: Oxford University Press; 2002:154-159.

40. Lodder J, Bamford JM, Sandercock PA, Jones LN, Warlow CP. Are hypertension or cardiac embolism likely causes of lacunar infarction? Stroke. 1990;21:375-381

41. Vernooij MW, van der Lugt A, Ikram MA, Wielopolski PA, Niessen WJ, Hofman A, Krestin GP, Breteler MM. Prevalence and risk factors of cerebral microbleeds: the Rotterdam Scan Study. Neurology. 2008;70:1208-1214

42. Greenberg SM, Vernooij MW, Cordonnier C, Viswanathan A, Al-Shahi Salman R, Warach S, Launer LJ, Van Buchem MA, Breteler MM. Cerebral microbleeds: a guide to detection and interpretation. Lancet Neurol. 2009;8:165-174

43. Henskens LH, van Oostenbrugge RJ, Kroon AA, de Leeuw PW, Lodder J. Brain microbleeds are associated with ambulatory blood pressure levels in a hypertensive population. Hypertension. 2008;51:62-68

44. Staals J, van Oostenbrugge RJ, Knottnerus IL, Rouhl RP, Henskens LH, Lodder J. Brain microbleeds relate to higher ambulatory blood pressure levels in first-ever lacunar stroke patients. Stroke. 2009;40:3264-3268 
45. Barkhof F. Enlarged Virchow-Robin spaces: do they matter? J Neurol Neurosurg Psychiatry. 2004;75:1516-1517

46. Maclullich AM, Wardlaw JM, Ferguson KJ, Starr JM, SeckI JR, Deary IJ. Enlarged perivascular spaces are associated with cognitive function in healthy elderly men. J Neurol Neurosurg Psychiatry. 2004;75:1519-1523

47. Wuerfel J, Haertle M, Waiczies H, Tysiak E, Bechmann I, Wernecke KD, Zipp F, Paul F. Perivascular spaces--MRI marker of inflammatory activity in the brain? Brain. 2008;131:2332-2340

48. Hiroki M, Miyashita K. Linear hyperintensity objects on magnetic resonance imaging related to hypertension. Cerebrovasc Dis. 2001;11:164-168

49. Persidsky Y, Ramirez SH, Haorah J, Kanmogne GD. Blood-brain barrier: structural components and function under physiologic and pathologic conditions. J Neuroimmune Pharmacol. 2006;1:223-236

50. Zlokovic BV. The blood-brain barrier in health and chronic neurodegenerative disorders. Neuron. 2008;57:178-201

51. Wardlaw JM. What causes lacunar stroke? J Neurol Neurosurg Psychiatry. 2005;76:617-619

52. Wardlaw JM, Sandercock PA, Dennis MS, Starr J. Is breakdown of the blood-brain barrier responsible for lacunar stroke, leukoaraiosis, and dementia? Stroke. 2003;34:806-812

53. Lammie A. The role of oedema in lacune formation. Cerebrovasc Dis. 1998;8:246

54. Wardlaw JM, Farrall A, Armitage PA, Carpenter T, Chappell F, Doubal F, Chowdhury D, Cvoro V, Dennis MS. Changes in background blood-brain barrier integrity between lacunar and cortical ischemic stroke subtypes. Stroke. 2008;39:1327-1332

55. Wardlaw JM, Doubal F, Armitage P, Chappell F, Carpenter T, Munoz Maniega S, Farrall A, Sudlow C, Dennis M, Dhillon B. Lacunar stroke is associated with diffuse blood-brain barrier dysfunction. Ann Neurol. 2009;65:194-202

56. Starr JM, Wardlaw J, Ferguson K, MacLullich A, Deary IJ, Marshall I. Increased blood-brain barrier permeability in type II diabetes demonstrated by gadolinium magnetic resonance imaging. J Neurol Neurosurg Psychiatry. 2003;74:70-76

57. Topakian R, Barrick TR, Howe FA, Markus HS. Blood-brain barrier permeability is increased in normalappearing white matter in patients with lacunar stroke and leucoaraiosis. I Neurol Neurosurg Psychiatry. 2010;81:192-197

58. Tzvetanov P, Nicoloff G, Rousseff R, Christova P. Increased levels of elastin-derived peptides in cerebrospinal fluid of patients with lacunar stroke. Clin Neurol Neurosurg. 2008;110:239-244

59. Bechmann I, Galea I, Perry VH. What is the blood-brain barrier (not)? Trends Immunol. 2007;28:5-11

60. Tervaert JW, Kallenberg CG. Cell adhesion molecules in vasculitis. Curr Opin Rheumatol. 1997;9:16-25

61. Fassbender K, Bertsch T, Mielke O, Muhlhauser F, Hennerici M. Adhesion molecules in cerebrovascular diseases. Evidence for an inflammatory endothelial activation in cerebral large- and small-vessel disease. Stroke. 1999;30:1647-1650

62. Hassan A, Hunt BJ, O'Sullivan M, Parmar K, Bamford JM, Briley D, Brown MM, Thomas DJ, Markus HS. Markers of endothelial dysfunction in lacunar infarction and ischaemic leukoaraiosis. Brain. 2003;126:424-432

63. Han JH, Wong KS, Wang YY, Fu JH, Ding D, Hong Z. Plasma level of sICAM-1 is associated with the extent of white matter lesion among asymptomatic elderly subjects. Clin Neurol Neurosurg. 2009;111:847-851

64. de Leeuw FE, de Kleine M, Frijns CJ, Fijnheer R, van Gijn J, Kappelle L. Endothelial cell activation is associated with cerebral white matter lesions in patients with cerebrovascular disease. Ann N Y Acad Sci. 2002;977:306-314

65. Kario K, Matsuo T, Kobayashi H, Asada R, Matsuo M. 'Silent' cerebral infarction is associated with hypercoagulability, endothelial cell damage, and high $L p(a)$ levels in elderly Japanese. Arterioscler Thromb Vasc Biol. 1996;16:734-741

66. Kearney-Schwartz A, Rossignol P, Bracard S, Felblinger J, Fay R, Boivin JM, Lecompte T, Lacolley P, Benetos A, Zannad F. Vascular structure and function is correlated to cognitive performance and white matter hyperintensities in older hypertensive patients with subjective memory complaints. Stroke. 2009;40:1229-1236

67. Markus HS, Hunt B, Palmer K, Enzinger C, Schmidt H, Schmidt R. Markers of endothelial and hemostatic activation and progression of cerebral white matter hyperintensities: longitudinal results of the Austrian Stroke Prevention Study. Stroke. 2005;36:1410-1414 
68. Markus HS. Genes, endothelial function and cerebral small vessel disease in man. Exp Physiol. 2008;93:121-127

69. Ghosh S, May MJ, Kopp EB. NF-kappa B and Rel proteins: evolutionarily conserved mediators of immune responses. Annu Rev Immunol. 1998;16:225-260

70. Schubert SY, Benarroch A, Monter-Solans J, Edelman ER. Monocyte activation state regulates monocyte-induced endothelial proliferation through Met signaling. Blood. 2010;115:3407-2412

71. Fuchs D, Weiss G, Reibnegger $\mathrm{G}$, Wachter $\mathrm{H}$. The role of neopterin as a monitor of cellular immune activation in transplantation, inflammatory, infectious, and malignant diseases. Crit Rev Clin Lab Sci. 1992;29:307-341

72. van Haelst PL, Liem A, van Boven AJ, Veeger NJ, van Veldhuisen DJ, Tervaert JW, Gans RO, Zijlstra F. Usefulness of elevated neopterin and C-reactive protein levels in predicting cardiovascular events in patients with non-Q-wave myocardial infarction. Am J Cardiol. 2003;92:1201-1203

73. Wright CB, Moon Y, Paik MC, Brown TR, Rabbani L, Yoshita M, DeCarli C, Sacco R, Elkind MS. Inflammatory biomarkers of vascular risk as correlates of leukoariosis. Stroke. 2009;40:3466-3471

74. van Dijk EJ, Prins ND, Vermeer SE, Vrooman HA, Hofman A, Koudstaal PJ, Breteler MM. C-reactive protein and cerebral small-vessel disease: the Rotterdam Scan Study. Circulation. 2005;112:900-905

75. Wada M, Nagasawa H, Kurita K, Koyama S, Arawaka S, Kawanami T, Tajima K, Daimon M, Kato T. Cerebral small vessel disease and $\mathrm{C}$-reactive protein: results of a cross-sectional study in communitybased Japanese elderly. J Neurol Sci. 2008;264:43-49

76. Fornage M, Chiang YA, O'Meara ES, Psaty BM, Reiner AP, Siscovick DS, Tracy RP, Longstreth WT, Jr. Biomarkers of Inflammation and MRI-Defined Small Vessel Disease of the Brain: The Cardiovascular Health Study. Stroke. 2008;39:1952-1959

77. Reitz C, Berger K, de Maat MP, Stoll M, Friedrichs F, Kardys I, Witteman JC, Breteler MM. CRP gene haplotypes, serum CRP, and cerebral small-vessel disease: the Rotterdam Scan Study and the MEMO Study. Stroke. 2007;38:2356-2359

78. Cirillo P, Pacileo M, S DER, Calabro P, Gargiulo A, Angri V, Granato-Corigliano F, Fiorentino I, Prevete N, R DEP, Mauro C, Leonardi A, Chiariello M. Neopterin induces pro-atherothrombotic phenotype in human coronary endothelial cells. J Thromb Haemost. 2006;4:2248-2255

79. Steinberg D. Lewis A. Conner Memorial Lecture. Oxidative modification of LDL and atherogenesis. Circulation. 1997;95:1062-1071

80. Glass CK, Witztum JL. Atherosclerosis. the road ahead. Cell. 2001;104:503-516

81. Ross R. Atherosclerosis--an inflammatory disease. N Engl J Med. 1999;340:115-126

82. Lewis MJ, Malik TH, Ehrenstein MR, Boyle JJ, Botto M, Haskard DO. Immunoglobulin m is required for protection against atherosclerosis in low-density lipoprotein receptor-deficient mice. Circulation. 2009;120:417-426

83. Su J, Georgiades A, Wu R, Thulin T, de Faire U, Frostegard J. Antibodies of IgM subclass to phosphorylcholine and oxidized LDL are protective factors for atherosclerosis in patients with hypertension. Atherosclerosis. 2006;188:160-166

84. Tsimikas S, Brilakis ES, Lennon RJ, Miller ER, Witztum JL, McConnell JP, Kornman KS, Berger PB. Relationship of IgG and IgM autoantibodies to oxidized low density lipoprotein with coronary artery disease and cardiovascular events. J Lipid Res. 2007;48:425-433

85. van Leeuwen M, Damoiseaux J, Duijvestijn A, Tervaert JW. The therapeutic potential of targeting $B$ cells and anti-oxLDL antibodies in atherosclerosis. Autoimmun Rev. 2009;9:53-57

86. Shoenfeld Y, Wu R, Dearing LD, Matsuura E. Are anti-oxidized low-density lipoprotein antibodies pathogenic or protective? Circulation. 2004;110:2552-2558

87. Walter DH, Rittig K, Bahlmann FH, Kirchmair R, Silver M, Murayama T, Nishimura H, Losordo DW, Asahara T, Isner JM. Statin therapy accelerates reendothelialization: a novel effect involving mobilization and incorporation of bone marrow-derived endothelial progenitor cells. Circulation. 2002;105:3017-3024

88. Werner N, Junk S, Laufs U, Link A, Walenta K, Bohm M, Nickenig G. Intravenous transfusion of endothelial progenitor cells reduces neointima formation after vascular injury. Circ Res. 2003;93: e17-24 
89. Fujiyama S, Amano K, Uehira K, Yoshida M, Nishiwaki Y, Nozawa Y, Jin D, Takai S, Miyazaki M, Egashira $\mathrm{K}$, Imada T, Iwasaka T, Matsubara H. Bone marrow monocyte lineage cells adhere on injured endothelium in a monocyte chemoattractant protein-1-dependent manner and accelerate reendothelialization as endothelial progenitor cells. Circ Res. 2003;93:980-989

90. Griese DP, Ehsan A, Melo LG, Kong D, Zhang L, Mann MJ, Pratt RE, Mulligan RC, Dzau VJ. Isolation and transplantation of autologous circulating endothelial cells into denuded vessels and prosthetic grafts: implications for cell-based vascular therapy. Circulation. 2003;108:2710-2715

91. Rabelink TJ, de Boer HC, van Zonneveld AJ. Endothelial activation and circulating markers of endothelial activation in kidney disease. Nat Rev Nephrol. 2010;6:404-414

92. Hill JM, Zalos G, Halcox JP, Schenke WH, Waclawiw MA, Quyyumi AA, Finkel T. Circulating endothelial progenitor cells, vascular function, and cardiovascular risk. N Engl J Med. 2003;348:593-600

93. Tao J, Wang Y, Yang Z, Tu C, Xu MG, Wang JM. Circulating endothelial progenitor cell deficiency contributes to impaired arterial elasticity in persons of advancing age. J Hum Hypertens. 2006;20: 490-495

94. Vasa M, Fichtlscherer S, Aicher A, Adler K, Urbich C, Martin H, Zeiher AM, Dimmeler S. Number and migratory activity of circulating endothelial progenitor cells inversely correlate with risk factors for coronary artery disease. Circ Res. 2001;89:E1-7

95. Delva P, Degan M, Vallerio P, Arosio E, Minuz P, Amen G, Di Chio M, Lechi A. Endothelial progenitor cells in patients with essential hypertension. J Hypertens. 2007;25:127-132

96. Oliveras A, Soler MJ, Martinez-Estrada OM, Vazquez S, Marco-Feliu D, Vila JS, Vilaro S, Lloveras J. Endothelial progenitor cells are reduced in refractory hypertension. J Hum Hypertens. 2008;22: 183-190

97. Werner N, Kosiol S, Schiegl T, Ahlers P, Walenta K, Link A, Bohm M, Nickenig G. Circulating endothelial progenitor cells and cardiovascular outcomes. N Engl J Med. 2005;353:999-1007

98. Schmidt-Lucke C, Rossig L, Fichtlscherer S, Vasa M, Britten M, Kamper U, Dimmeler S, Zeiher AM. Reduced number of circulating endothelial progenitor cells predicts future cardiovascular events: proof of concept for the clinical importance of endogenous vascular repair. Circulation. 2005;111:2981-2987

99. Ghani U, Shuaib A, Salam A, Nasir A, Shuaib U, Jeerakathil T, Sher F, O'Rourke F, Nasser AM, Schwindt B, Todd K. Endothelial progenitor cells during cerebrovascular disease. Stroke. 2005;36:151-153

100. Chu K, Jung KH, Lee ST, Park HK, Sinn DI, Kim JM, Kim DH, Kim JH, Kim SJ, Song EC, Kim M, Lee SK, Roh JK. Circulating endothelial progenitor cells as a new marker of endothelial dysfunction or repair in acute stroke. Stroke. 2008;39:1441-1447

101. Sobrino T, Hurtado O, Moro MA, Rodriguez-Yanez M, Castellanos M, Brea D, Moldes O, Blanco M, Arenillas JF, Leira R, Davalos A, Lizasoain I, Castillo J. The increase of circulating endothelial progenitor cells after acute ischemic stroke is associated with good outcome. Stroke. 2007;38:2759-2764

102. Taguchi A, Matsuyama T, Moriwaki H, Hayashi T, Hayashida K, Nagatsuka K, Todo K, Mori K, Stern DM, Soma T, Naritomi H. Circulating CD34-positive cells provide an index of cerebrovascular function. Circulation. 2004;109:2972-2975

103. Yip HK, Chang LT, Chang WN, Lu CH, Liou CW, Lan MY, Liu JS, Youssef AA, Chang HW. Level and value of circulating endothelial progenitor cells in patients after acute ischemic stroke. Stroke. 2008;39:69-74

104. Staals J, Pieters BMA, Knottnerus ILH, Rouhl RPW, van Oostenbrugge RJ, Delanghe JR, Lodder J. Haptoglobin polymorphism and lacunar stroke. Curr Neurovasc Res. 2008;5:153-158

105. Lohr NL, Warltier DC, Chilian WM, Weihrauch D. Haptoglobin expression and activity during coronary collateralization. Am J Physiol Heart Circ Physiol. 2005;288:H1389-1395

106. Hur J, Yang HM, Yoon CH, Lee CS, Park KW, Kim JH, Kim TY, Kim JY, Kang HJ, Chae IH, Oh BH, Park YB, Kim HS. Identification of a novel role of $T$ cells in postnatal vasculogenesis: characterization of endothelial progenitor cell colonies. Circulation. 2007;116:1671-1682 


\section{Chapter 2}

Virchow-Robin spaces relate to cerebral small vessel disease severity

RPW Rouhl

RJ van Oostenbrugge

ILH Knottnerus

JEA Staals

J Lodder

Journal of Neurology 2008;255:692-696 


\section{Abstract}

\section{Background and purpose}

Virchow-Robin spaces are perivascular spaces surrounding the deep perforating brain arteries. Virchow-Robin spaces enlargement is pathologic, and it could be a manifestation of cerebral small vessel disease. In the present study we assessed the relation between Virchow-Robin spaces and silent ischemic lesions in a cohort of patients with cerebral small vessel disease.

\section{Methods}

We divided enlarged Virchow-Robin spaces on MRI (1.5 Tesla) into three semiquantitative categories in 165 first ever lacunar stroke patients. We counted asymptomatic lacunar infarcts and graded white matter lesions, and compared the prevalence of vascular risk factors in different categories of Virchow-Robin spaces. We also determined independent predictors of silent ischemic lesions.

\section{Results}

Virchow-Robin spaces at basal ganglia level related to age, hypertension, asymptomatic lacunar infarcts, and white matter lesions. Virchow-Robin spaces at basal ganglia level predicted silent ischemic lesions (Odds Ratio 10.58 per higher Virchow-Robin spaces category; 95\%-Confidence Interval 3.40-32.92).

\section{Conclusion}

Enlarged Virchow-Robin spaces in the basal ganglia relate to the severity of cerebral small vessel disease and might be a manifestation of the same small vessel abnormality that causes silent ischemic lesions. This adds a role for Virchow-Robin spaces as a potential marker for small vessel disease. 


\section{Introduction}

Virchow-Robin spaces (VRs) are perivascular spaces surrounding the perforating brain arteries and arterioles. Pia mater forms both inner and outer boundaries of this space. Especially when enlarged and filled with fluid, VRs are visible on MR imaging. Enlarged VRs usually measure up to $3 \mathrm{~mm}$ in diameter on MRI, but sometimes up to $15 \mathrm{~mm}$. Dilatation of VRs has been attributed to vascular ectasia and tortuosity, increased vessel wall permeability, a decrease in vascular compliance, ischemic perivascular tissue loss, and to an ex vacuo phenomenon in cortical atrophy. ${ }^{1,2}$

The findings that enlarged VRs relate to extensive white matter lesions (WML, also known as leukoaraiosis in CT imaging), ${ }^{2}$ to hypertension, ${ }^{3}$ to depression in the elderly, ${ }^{4}$ and to retinopathy in diabetics, ${ }^{5}$ point to a general relation between VRs and cerebral small vessel disease. Patankar et al. specifically related VRs to a (micro)vascular cause in patients with dementia. ${ }^{6}$ However, cerebral small vessel disease is the common denominator of several different pathological alterations. ${ }^{7}$ Furthermore, systematic studies of VRs in patients with symptomatic cerebral small vessel disease are lacking. We therefore studied the relation between enlarged VRs and vascular risk factors as well as cerebral small vessel disease severity in terms of silent lacunar lesions and WML in a well-defined cohort of first-ever lacunar stroke patients.

\section{Patients and Methods}

We included all patients with a first lacunar stroke, registered in the prospective Maastricht Stroke Registry ${ }^{8}$ from September 1999 to May 2005, of whom an MRI of the brain was available $(\mathrm{N}=165)$. We defined lacunar stroke as an acute stroke syndrome with a lesion on imaging compatible with the occlusion of a single perforating artery, consisting of a subcortical, demarcated lesion with a diameter $<20 \mathrm{~mm}$. If no such lesion was visible on imaging, we used established criteria of unilateral motor and/or sensory signs that involved the whole of at least 2 of the 3 body parts (face, arm, leg), without disturbance of consciousness, visual fields, language, or other cortical functions. ${ }^{8}$ Patients with potential cardiac embolic source of stroke or cerebral large vessel disease were not included.

We recorded the vascular risk factor profile defined as previously. ${ }^{8} \mathrm{MR}$ images (field of view 23*23 cm, matrix 512*512; standard axial T2 (TR shortest, TE $100 \mathrm{~ms}$ ) and axial fluid attenuated inversion recovery (FLAIR) (TR 8000 ms, TE $120 \mathrm{~ms}$ ) images, all with slice thickness $5 \mathrm{~mm}$ and gaps of $0.50 \mathrm{~mm}$ ) were obtained with a 1.5 Tesla MR scanner (Philips). Two vascular neurologists (R.J. van Oostenbrugge and J. Lodder) assessed MR images by consensus. We defined the symptomatic lacunar infarct as a hyperintense lesion of $<15 \mathrm{~mm}$ in diameter on T2 and FLAIR images, with its site compatible to the clinical syndrome. We counted asymptomatic lacunar infarcts, which we defined as hyperintense lesions on T2 images with corresponding hypointense lesions with a 
hyperintense rim on FLAIR and a diameter of $<15 \mathrm{~mm}$. We distinguished round or oval VRs at two different levels: the basal ganglia (BG-VRs), and the white matter of the centrum semiovale (CSO-VRs). We counted linear hyperintensities in the white matter of the centrum semiovale (L-VRs). Because BG-VRs and CSO-VRs could not be individually identified as continuous structures on different slices, we counted these on each slice separately. For each level separately, we divided the total number of VRs in both hemispheres together into three arbitrary semi-quantitative categories: 1) lower than 20 ("low"), 2) between 20 and 50 ("moderate") and 3) higher than 50 ("high"). The criteria for VRs were: 1) round, oval or linear shape with a smooth margin, 2) signal intensity equal to that of the cerebrospinal fluid on T2-images (larger VRs can be visible as hypointense lesions on FLAIR images, but always without hyperintense rim), and 3) absence of mass effect. ${ }^{9-11}$ Figure 2.1 illustrates category 3 BG-VRs. We graded periventricular and deep WML using the Fazekas scale. ${ }^{12} \mathrm{We}$ assessed brain atrophy semiquantitatively by visual comparison to example scans with no, mild, moderate, or severe atrophy ${ }^{13}$ and also by the use of two indices (the bicaudate ratio and the Sylvian-fissure ratio). ${ }^{14}$ Prior to this study, two vascular neurologists (R.J. van Oostenbrugge and J. Lodder) independently assessed MR images of 101 first ever stroke patients to determine inter-observer agreement of our rating scale. Cohen's kappas were fair to excellent (according to published standard works on statistics): ${ }^{15} 0.89$ for symptomatic infarct, 0,96 for presence of one or more asymptomatic lacunar infarcts, 0.64 for BG-VRs, 0.57 for CSO-VRs, 0.72 for L-VRs, 0.77 for periventricular WML, and 0.84 for deep WML.

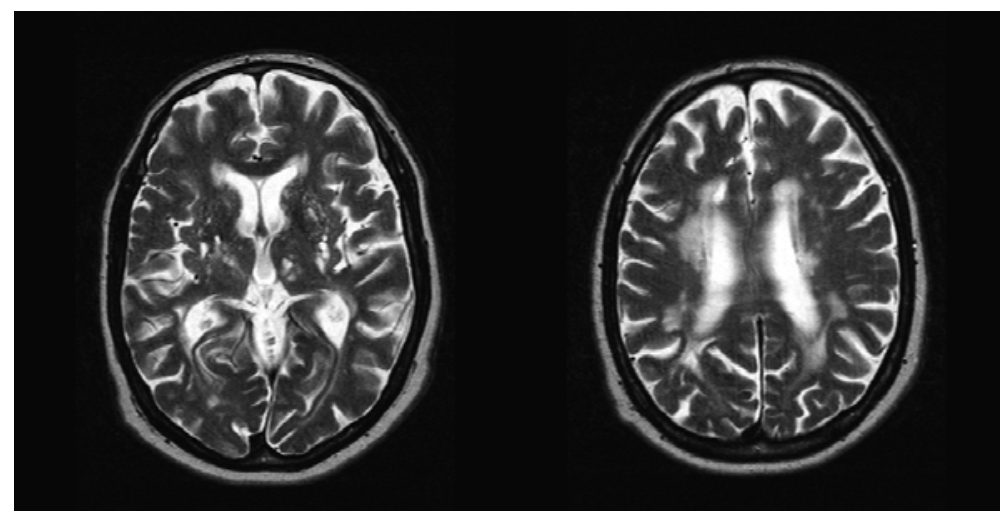

Figure 2.1 Co-occurrence of high numbers of VRs at the level of the basal ganglia, asymptomatic lacunar infarcts, and extensive white matter lesions on a T2-weighted MR image in a patient with a first-ever lacunar stroke. 


\section{Statistical analysis}

First, we compared frequencies of risk factors and radiological parameters in the different VRs categories using chi-square tests. To calculate independent associations we used regression analyses with VRs (at different levels separately) as dependent variable, and the risk factors and other radiological parameters as independent variables.

Second, we distinguished patients with at least one asymptomatic lacunar infarct and also extensive WML (silent ischemic lesions (SIL)+) with patients who did not fulfil these criteria (SIL-). We defined extensive WML as: periventricular WML score 3 (irregular lesions extending into deep white matter) and/or deep WML with score 2 (beginning confluence of lesions) or 3 (large confluent areas) on the Fazekas scale. ${ }^{12}$ Using binary logistic regression analyses with SIL as dependent variable we determined independent predictors of silent ischemic lesions, including VRs. All statistical analyses were done with SPSS (Statistical Package for the Social Sciences), version 12.0.1.

\section{Results}

Table 2.1 shows the frequencies of vascular risk factors and MRI characteristics, and significant results of univariate analyses for the three VRs categories for all 165 lacunar stroke patients. BG-VRs remained significantly associated to periventricular WML $(\beta=0.19, p<0.001)$, asymptomatic lacunar infarcts $(\beta=0.26, p<0.05)$, and age $(\beta=0.02$, $\mathrm{p}<0.001)$ in multivariate analysis. L-VRs remained significantly associated with both diabetes $(\beta=0.48, p<0.01)$ and asymptomatic lacunar infarcts $(\beta=0.28, p<0.05)$ in multivariate analysis. Atrophy data are not shown, no significance was reached in univariate as well as in multivariate analyses with both the semi-quantitative rating scale as well as with the atrophy ratios.

The only significant predictor of SIL+ was BG-VRs (adjusted odds ratio 10.58 (95\%confidence interval 3.40-32.92) for each higher BG-VRs category). Figure 2.2 shows the percentages of SIL+ and SIL- patients for each BG-VRs category. 
Table 2.1 Frequencies of risk factors and MRI parameters in different categories of VRs in lacunar stroke patients $(n=165)$ (Absolute patient numbers are given, percentages between parentheses, unless otherwise indicated).

\begin{tabular}{|c|c|c|c|c|c|c|c|c|}
\hline & $\begin{array}{l}\text { Age (mean } \\
\text { with SD) }\end{array}$ & Male sex & $\begin{array}{c}\text { Coronary } \\
\text { heart disease }\end{array}$ & Hypertension & Diabetes & $\begin{array}{l}\text { Asymptomatic } \\
\text { Lacunar Infarcts }\end{array}$ & $\begin{array}{c}\text { Extensive } \\
\text { Periventricular } \\
\text { WML }\end{array}$ & $\begin{array}{c}\text { Extensive Deep } \\
\text { WML }\end{array}$ \\
\hline \multicolumn{9}{|l|}{ Basal Ganglia VRs } \\
\hline Moderate $(n=59)$ & $64.0+/-11.4^{c}$ & $36(61.0)$ & $14(23.7)$ & $32(54.2)^{d}$ & $11(18.7)$ & $39(66.1)^{\mathrm{a}}$ & $21(35.6)^{\mathrm{a}}$ & $17(28.9)^{\mathrm{a}}$ \\
\hline High $(n=47)$ & $70.1+/-8.7^{c}$ & $26(55.3)$ & $6(12.8)$ & $32(68.1)^{d}$ & $5(10.6)$ & $39(83.0)^{a}$ & $27(57.4)^{a}$ & $27(57.4)^{\mathrm{a}}$ \\
\hline \multicolumn{9}{|c|}{ Centrum Semiovale VRs } \\
\hline Moderate $(n=53)$ & $64.9+/-10.4$ & $31(58.5)$ & $5(9.4)$ & $24(45.3)$ & $8(15.1)$ & $32(60.4)^{b}$ & $17(32.1)$ & $19(35.8)$ \\
\hline High $(n=51)$ & $64.7+/-12.1$ & $25(49.0)$ & $8(15.7)$ & $34(66.7)$ & $9(17.6)$ & $41(80.4)^{b}$ & $18(35.3)$ & $18(35.3)$ \\
\hline \multicolumn{9}{|l|}{ Linear VRs } \\
\hline Low (n=69) & $60.8+/-11.6$ & $43(62.3)$ & $11(15.6)$ & $32(46.4)$ & $3(4.3)^{d}$ & $35(50.7)^{d}$ & $11(15.9)$ & $19(27.5)$ \\
\hline Moderate $(n=61)$ & $65.1+/-11.1$ & $38(62.3)$ & $10(16.3)$ & $32(52.5)$ & $12(19.7)^{d}$ & $45(73.8)^{d}$ & 19 (31.1) & $22(36.1)$ \\
\hline High $(n=35)$ & $65.3+/-11.6$ & $18(51.4)$ & $4(11.4)$ & $25(71.4)$ & $8(22.9)^{d}$ & $24(68.6)^{d}$ & $18(51.4)$ & $7(20.0)$ \\
\hline
\end{tabular}

${ }^{a}$ : chi-square test; $p<0.001{ }^{\text {b }}$ : chi-square test; $p<0.01$; ${ }^{c}$ : Mann Whitney U-test; $p<0.01$; ${ }^{\text {d }}$ chi-square test; $p<0.05$. Extensive periventricular WML: score of 3 ('irregular lesions with extension into deep white matter'). ${ }^{12}$ Extensive deep WML: score of 2 ('beginning confluence of lesions'), or 3 ('large confluent areas') $)^{12}$

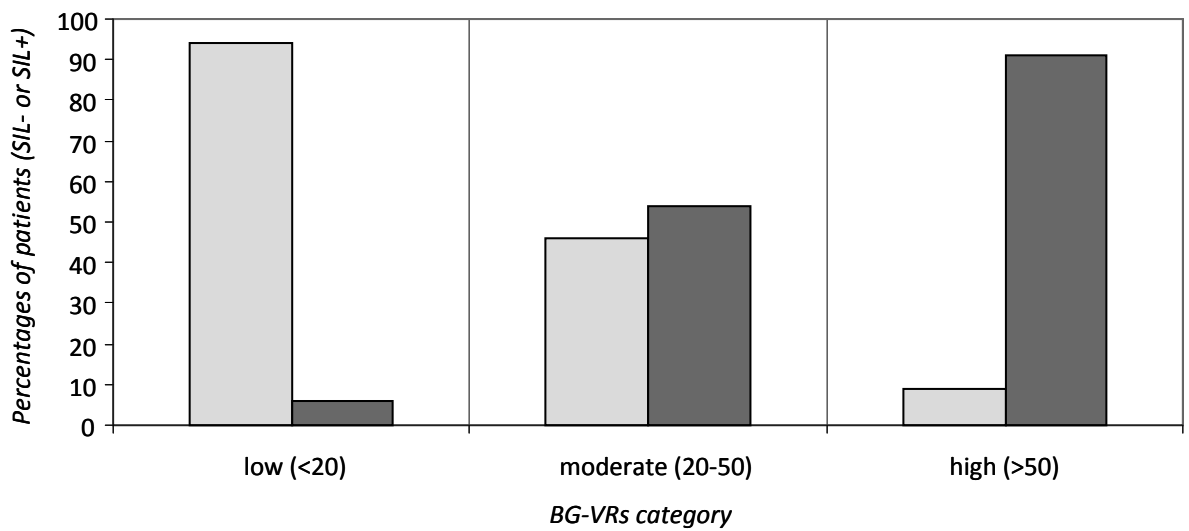

$\square$ No silent ischemic lesions (SIL-) $\square$ Silent ischemic lesions (SIL+)

Figure 2.2 Distribution of SIL- and SIL+ among BG-VRs categories.

\section{Discussion}

Enlarged VRs strongly correlate with silent ischemic lesions in our patients with a firstever lacunar stroke. Additionally, in a regression analysis, higher numbers of enlarged VRs at basal ganglia level strongly and independently predicted silent ischemic lesions with an odds ratio of more than 10 . This association between silent ischemic lesions and enlarged VRs could reflect the general burden of small vessel disease in our lacunar stroke series, with enlarged VRs being an epiphenomenon and marker of the severity of cerebral small vessel disease in general. État criblé (the presence of multiple 
dilated VRs) and état lacunaire (the presence of multiple lacunar infarcts) thus seem to merge into one single entity. ${ }^{16,17}$ However, such interpretation would disregard the heterogeneity of cerebral small vessel disease as demonstrated pathologically by Fischer ${ }^{18}$ and further suggested in several clinical studies. ${ }^{19,20}$ Lammie related multiple lacunar lesions and leukoaraiosis to small vessel arteriolosclerosis. ${ }^{7}$ Van Swieten et al. demonstrated arteriolosclerosis in most vessels in patients with WML, and found that enlarged VRs related to the presence of this type of small vessel disease. ${ }^{21}$ Pathological studies thus suggest that arteriolosclerosis underlies silent lacunar infarcts, WML as well as enlarged VRs. However, we should realize that evidence for the presence of small vessel arteriolosclerosis in clinical series is only indirect.

We studied these associations in patients with cerebral small vessel disease as we expected VRs numbers to be highest in this patient group. In cerebral large vessel disease patients $(n=41)$, associations were similar, however frequencies of high VRs numbers were lower (e.g. 17\% of large vessel disease patients had high numbers of BG-VRs vs. $28 \%$ in the small vessel disease group; data not shown).

Our study has limitations. First, our patient selection favoured younger, neurologically less disabled patients, able to undergo MRI. However, this selection would rather favour underestimation of VRs numbers and WML severity. Second, because neurovascular workup in our hospital includes axial T2 and FLAIR weighted images, we were unable to use Patankar's $\mathrm{s}^{4,6}$ or Scheltens' scale ${ }^{22}$ which also used T1 weighted and coronal images. The third limitation may be a restricted validity of MRI criteria to distinguish VRs from lacunar infarcts, especially in the basal ganglia region. As others, however, we applied criteria for distinction based on MRI-pathological studies. ${ }^{9-11} \mathrm{~A}$ fourth limitation may be the limited MRI protocol used. The omission of diffusion weighted imaging may both lead to overrecognition as well as underrecognition of symptomatic lacunar infarcts, leading to an underestimation of associations. Furthermore a higher field strength of 3 Tesla may render a higher yield in VRs, but also in lacunar infarcts, leading to even stronger associations. Therefore, the use of a 1.5 Tesla MR scanner unlikely leads to overestimation of the strength of associations. As a consequence of our scanning protocol, dotlike VRs could not be identified individually on different slices, which undoubtedly resulted in double countings of the same VRs. Therefore, VRs categories do not represent absolute numbers.

In conclusion, we found a strong independent association between the number of enlarged VRs in the basal ganglia, and small vessel disease severity in terms of silent lacunar infarcts and white matter lesions. This finding may point at a similar small vessel abnormality underlying enlarged VRs, white matter lesions and (silent) lacunar infarcts, which may be arteriolosclerosis in most cases. 


\section{References}

1. Barkhof F. Enlarged Virchow-Robin spaces: do they matter? J Neurol Neurosurg Psychiatry. 2004;75:1516-1517

2. Maclullich AM, Wardlaw JM, Ferguson KJ, Starr JM, Seckl JR, Deary IJ. Enlarged perivascular spaces are associated with cognitive function in healthy elderly men. J Neurol Neurosurg Psychiatry. 2004; 75:1519-1523

3. Hiroki M, Miyashita K. Linear hyperintensity objects on magnetic resonance imaging related to hypertension. Cerebrovasc Dis. 2001;11:164-168

4. Patankar TF, Baldwin R, Mitra D, Jeffries S, Sutcliffe C, Burns A, Jackson A. Virchow-Robin space dilatation may predict resistance to antidepressant monotherapy in elderly patients with depression. J Affect Disord. 2007;97:265-270

5. Ferguson SC, Blane A, Perros P, McCrimmon RJ, Best JJ, Wardlaw J, Deary IJ, Frier BM. Cognitive ability and brain structure in type 1 diabetes: relation to microangiopathy and preceding severe hypoglycemia. Diabetes. 2003;52:149-156

6. Patankar TF, Mitra D, Varma A, Snowden J, Neary D, Jackson A. Dilatation of the Virchow-Robin space is a sensitive indicator of cerebral microvascular disease: study in elderly patients with dementia. AJNR Am J Neuroradiol. 2005;26:1512-1520

7. Lammie G. Pathology of lacunar infarction. In: Donnan G, Norrving B, Bamford J, Bogousslavsky J, eds. Subcortical Stroke. Oxford: Oxford University Press; 2002:37-46.

8. de Jong G, Kessels F, Lodder J. Two types of lacunar infarcts: further arguments from a study on prognosis. Stroke. 2002;33:2072-2076

9. Song CJ, Kim JH, Kier EL, Bronen RA. MR imaging and histologic features of subinsular bright spots on T2-weighted MR images: Virchow-Robin spaces of the extreme capsule and insular cortex. Radiology. 2000;214:671-677

10. Bokura H, Kobayashi S, Yamaguchi S. Distinguishing silent lacunar infarction from enlarged VirchowRobin spaces: a magnetic resonance imaging and pathological study. J Neurol. 1998;245:116-122

11. Takao M, Koto A, Tanahashi N, Fukuuchi Y, Takagi M, Morinaga S. Pathologic findings of silent, small hyperintense foci in the basal ganglia and thalamus on MRI. Neurology. 1999;52:666-668

12. Fazekas F, Chawluk JB, Alavi A, Hurtig HI, Zimmerman RA. MR signal abnormalities at $1.5 \mathrm{~T}$ in Alzheimer's dementia and normal aging. AJR Am J Roentgenol. 1987;149:351-356

13. Rasquin SM, Verhey FR, van Oostenbrugge RJ, Lousberg R, Lodder J. Demographic and CT scan features related to cognitive impairment in the first year after stroke. J Neurol Neurosurg Psychiatry. 2004;75:1562-1567

14. van Zagten $\mathrm{M}$, Kessels $\mathrm{F}$, Boiten J, Lodder J. Interobserver agreement in the assessment of cerebral atrophy on CT using bicaudate and sylvian-fissure ratios. Neuroradiology. 1999;41:261-264

15. Sackett D, Haynes R, Tugwell P, Guyatt G. Clinical Epidemiology: A Basic Science for Clinical Medicine. Baltimore: Lippincott Williams \& Wilkins; 1991.

16. Poirier J, Derouesne C. [The concept of cerebral lacunae from 1838 to the present]. Rev Neurol (Paris). 1985;141:3-17

17. Poirier J, Derouesne C. Distinguishing lacunar infarcts from dilatations of the perivascular space. J Neurol. 1998;245:813-814

18. Fisher CM. Lacunar strokes and infarcts: a review. Neurology. 1982;32:871-876

19. Khan U, Porteous L, Hassan A, Markus HS. Risk factor profile of cerebral small vessel disease and its subtypes. J Neurol Neurosurg Psychiatry. 2007;78:702-706

20. Wardlaw JM. What causes lacunar stroke? J Neurol Neurosurg Psychiatry. 2005;76:617-619

21. van Swieten JC, van den Hout JH, van Ketel BA, Hijdra A, Wokke JH, van Gijn J. Periventricular lesions in the white matter on magnetic resonance imaging in the elderly. A morphometric correlation with arteriolosclerosis and dilated perivascular spaces. Brain. 1991;114 ( Pt 2):761-774

22. Scheltens $P$, Barkhof $F$, Leys D, Pruvo JP, Nauta JJ, Vermersch P, Steinling M, Valk J. A semiquantative rating scale for the assessment of signal hyperintensities on magnetic resonance imaging. J Neurol Sci. $1993 ; 114: 7-12$ 


\section{Chapter 3}

\section{Auto-antibodies against oxidized LDL in cerebral small vessel disease}

RPW Rouhl

RJ van Oostenbrugge

ROMFIH Theunissen

ILH Knottnerus

J Staals

LHG Henskens

AA Kroon

PW de Leeuw

J Lodder

JW Cohen Tervaert

JGMC Damoiseaux

Stroke 2010;41:2687-2689 


\section{Abstract}

\section{Background and purpose}

Oxidized Low Density Lipoprotein (oxLDL) induces endothelial dysfunction and antibody formation. As endothelial dysfunction is involved in cerebral small vessel disease (CSVD: enlarged Virchow Robin spaces, lacunar infarcts, and white matter lesions), oxLDL-antibodies could play a role in CSVD pathogenesis. Therefore, we studied oxLDL antibodies in patients with high prevalence of CSVD: lacunar stroke patients and essential hypertensive patients.

\section{Methods}

158 lacunar stroke patients, 158 hypertensive patients, and 43 healthy controls were included. We determined levels of IgG and IgM against hypochlorite ( $\mathrm{HOCl}$ ) and malondialdehyde (MDA) oxidized LDL using ELISA (values in optical density).

\section{Results}

Patients with CSVD had higher levels of IgG-HOCl-oxLDL $(0.77$ versus $0.70 ; p<0.01)$ as well as lower levels of IgM-MDA-oxLDL (0.55 versus $0.65 ; \mathrm{p}<0.05)$ than patients without such lesions. Higher IgG-HOCl-oxLDL-levels were only independently associated with higher numbers of Virchow Robin spaces at the level of the basal ganglia $(\beta=0.218 ; p<0.001)$.

\section{Conclusion}

An autoinflammatory process with lower levels of IgM-antibodies and higher levels of IgG-antibodies against oxLDL may be involved in CSVD. 


\section{Introduction}

Oxidized Low Density Lipoprotein (oxLDL) has an established role in the pathogenesis of atherosclerosis. It acts as a pro-inflammatory and pro-atherogenic compound by inducing auto-antibodies and endothelial dysfunction. ${ }^{1}$ Next to involvement in atherosclerosis, anti-oxLDL antibodies could also play a role in cerebral small vessel disease (CSVD).

In CSVD, endothelial dysfunction is considered to increase the permeability of the blood-brain barrier, with enlargement of the perivascular (Virchow Robin) spaces, (a)symptomatic lacunar infarcts, and white matter lesions as sequelae. ${ }^{2}$ However, it is still unclear which mechanisms promote endothelial dysfunction in CSVD. Given their role in causing endothelial dysfunction in atherosclerosis, anti-oxLDL antibodies may contribute to the pathogenesis of CSVD as well.

We hypothesized that patients with CSVD have higher levels of antibodies against oxLDL than patients without such lesions or healthy controls. To test our hypothesis, we selected two patient groups with a high prevalence of manifestations of CSVD: firstever lacunar stroke patients, as well as patients with essential hypertension.

\section{Patients and methods}

\section{Patients}

We prospectively included 158 first-ever lacunar stroke patients presenting at the department of Neurology between May 2003 and December 2007. Lacunar stroke was defined as an acute stroke syndrome with a lesion on imaging compatible with the occlusion of a single perforating small artery (subcortical, demarcated and a diameter $<15 \mathrm{~mm}$ on MRI). ${ }^{3}$ Furthermore, other possible causes (cardiac embolism, large vessel disease, or carotid stenosis) were excluded. ${ }^{3}$ In addition, we included 158 consecutive hypertensive patients from the outpatient department of Internal Medicine. At inclusion these patients were free of comorbidity. ${ }^{4}$ Forty-three patients who visited the neurological outpatient department with myogenic back pain or entrapment neuropathies served as "healthy" controls. They had no vascular or inflammatory disease, no hypertension, nor silent ischemic lesions on cerebral MRI.

\section{MRI}

Both standard T2-weighted and fluid-attenuated inversion-recovery sequences were used. Images were assessed by consensus by two experienced neurovascular researchers (R.P.W. Rouhl and R.J. van Oostenbrugge). ${ }^{5}$ In case of disagreement, the judgement of a third (J. Lodder) was decisive. We counted asymptomatic lacunar infarcts and used the Fazekas-scale for white matter lesions (WML). ${ }^{6}$ Extensive WML 
were defined as periventricular hyperintensities with extension into white matter, and/or beginning confluence of lesions or large confluent lesions in deep white matter. Silent CSVD was defined as the presence of one or more asymptomatic infarcts and/or extensive WML. Furthermore, we assessed another manifestation of CSVD, namely Virchow Robin spaces at three different levels with a predefined three point scale: ${ }^{5} 1$ ) $<20,2$ ) between 20 and 50, and 3) $>50$.

\section{OxLDL-antibodies}

To prevent confounding by acute phase responses in lacunar stroke patients, blood was sampled at or around 3 months after their event, in a stable clinical condition. We determined IgG- as well as IgM-antibodies against two different forms of oxidized LDL (malondialdehyde (MDA) modified as well as hypochlorite ( $\mathrm{HOCl}$ ) oxidized LDL) according to methods we described earlier. ${ }^{7}$ Results are expressed as netto optical density (OD): for each patient results of native LDL wells were subtracted from results of oxLDL wells. Interassay-variability was $<10 \%$.

\section{Statistical analysis}

First, we compared autoantibody levels between patients with or without small vessel disease characteristics with Mann Whitney tests. We also compared antibody levels between all three patient categories using Kruskal-Wallis test; whenever this test revealed significant differences, we used Mann-Whitney tests with correction for multiple testing (adjusted $p<0.017$ ) to evaluate differences between patients and controls. Finally, we determined independent relations between log-transformed IgG-oxLDL levels and MRI characteristics of CSVD using multivariate linear regression analyses. IgM-oxLDL values could not be transformed into normally distributed data. Unless indicated otherwise, we considered a $p$-value of $<0.05$ statistically significant.

\section{Results}

Characteristics of patients and controls are shown in Table 3.1. Differences in antibody levels between patients with or without silent lesions are shown in Table 3.2, whereas results of the antibody measurements for the different patient groups separately are shown in Figure 3.1.

The only significant independent predictor of the log-lgG-HOCl-oxLDL levels was the number of Virchow Robin spaces at basal ganglia level ( $B=0.033$; 95\%-confidence interval 0.017-0.049; $\beta=0.218 ; p<0.001)$. Results were corrected for age, sex, hypertension, patient category as well as for coronary and peripheral artery disease. 
Table 3.1 Patient and control characteristics. p-values represent differences in distribution among all patient categories.

\begin{tabular}{lcccc}
\hline & $\begin{array}{c}\text { Lacunar Stroke } \\
\text { Patients }(\mathrm{n}=158)\end{array}$ & $\begin{array}{c}\text { Hypertensive } \\
\text { Patients }(\mathrm{n}=158)\end{array}$ & $\begin{array}{c}\text { Healthy Controls } \\
(\mathrm{n}=43)\end{array}$ & p-value \\
\hline Age (mean ( \pm standard deviation (SD)) & $64.0(12.1)$ & $54.7(13.5)$ & $62.2(7.7)$ & $<0.001$ \\
Male sex (n (\%)) & $97(61.4)$ & $83(52.5)$ & $20(45.5)$ & 0.11 \\
Hypertension (n (\%)) & $102(64.6)$ & $158(100.0)$ & $0(0.0)$ & $<0.001$ \\
Coronary artery disease (n (\%)) & $22(13.9)$ & $16(10.1)$ & $0(0.0)$ & 0.03 \\
Peripheral Vascular Disease (n (\%)) & $6(3.8)$ & $4(2.5)$ & $0(0.0)$ & 0.41 \\
Diabetes (n (\%)) & $18(11.4)$ & $6(3.8)$ & $0(0.0)$ & 0.003 \\
Hypercholesterolemia (n (\%)) & $124(78.5)$ & $64(40.5)$ & $10(22.7)$ & $<0.001$ \\
Current Smoking (n (\%)) & $58(36.7)$ & $30(19.0)$ & $14(31.8)$ & $<0.001$ \\
Statin Use (n (\%)) & $145(91.4)$ & $63(39.9)$ & $3(6.8)$ & $<0.001$ \\
Antihypertensive use (n (\%)) & $105(66.5)$ & $143(90.5)$ & $0(0.0)$ & $<0.001$ \\
\hline
\end{tabular}

Table 3.2 Median anti-oxLDL levels (in netto OD values) and IgG/IgM ratios in different patient groups, classified by MRI.

\begin{tabular}{|c|c|c|c|c|c|c|c|c|c|c|}
\hline & \multicolumn{2}{|c|}{$\begin{array}{l}\text { Asymptomatic } \\
\text { Lacunar Infarcts }\end{array}$} & \multicolumn{2}{|c|}{$\begin{array}{c}\text { Extensive } \\
\text { Periventricular } \\
\text { WML }\end{array}$} & \multicolumn{2}{|c|}{$\begin{array}{c}\text { Extensive Deep } \\
\text { WML }\end{array}$} & \multicolumn{2}{|c|}{$\begin{array}{c}\text { Extensive } \\
\text { WML }\end{array}$} & \multicolumn{2}{|c|}{ Silent CSVD } \\
\hline & $\begin{array}{c}\text { Yes } \\
(n=110)\end{array}$ & $\begin{array}{c}\text { No } \\
(n=248)\end{array}$ & $\begin{array}{c}\text { Yes } \\
(n=60)\end{array}$ & $\begin{array}{c}\text { No } \\
(n=298)\end{array}$ & $\begin{array}{c}\text { Yes } \\
(n=61)\end{array}$ & $\begin{array}{c}\text { No } \\
(n=297)\end{array}$ & $\begin{array}{c}\text { Yes } \\
(n=77)\end{array}$ & $\begin{array}{c}\text { No } \\
(n=281)\end{array}$ & $\begin{array}{c}\text { Yes } \\
(n=140)\end{array}$ & $\begin{array}{c}\text { No } \\
(n=218)\end{array}$ \\
\hline IgM-MDA-oxLDL & 0.56 & $0.63^{\mathrm{a}}$ & 0.51 & $0.63^{\mathrm{a}}$ & 0.51 & $0.63^{\mathrm{a}}$ & 0.52 & $0.64^{\mathrm{a}}$ & 0.55 & $0.65^{\mathrm{a}}$ \\
\hline IgG-MDA-oxLDL & 0.19 & 0.17 & 0.18 & 0.17 & 0.18 & 0.17 & 0.18 & 0.17 & 0.18 & 0.17 \\
\hline IgM-HOCl-oxLDL & 0.12 & $0.08^{b}$ & 0.10 & 0.10 & 0.10 & 0.10 & 0.10 & 0.09 & 0.11 & 0.09 \\
\hline IgG-HOCl-oxLDL & 0.79 & $0.70^{c}$ & 0.76 & 0.72 & 0.77 & 0.72 & 0.75 & 0.72 & 0.77 & $0.70^{b}$ \\
\hline IgG/IgM-MDA ratio & 0.35 & $0.26^{c}$ & 0.32 & $0.28^{c}$ & 0.40 & $0.27^{c}$ & 0.34 & $0.27^{c}$ & 0.33 & $0.26^{c}$ \\
\hline IgG/IgM-HOCl ratio & 7.46 & 7.46 & 7.17 & 7.52 & 6.80 & 7.85 & 6.80 & 7.85 & 7.21 & 8.03 \\
\hline
\end{tabular}

Statistically significant differences as indicated: ${ }^{a} p<0.05 ;{ }^{b} p<0.01 ;{ }^{c} p<0.001$ (No versus Yes).

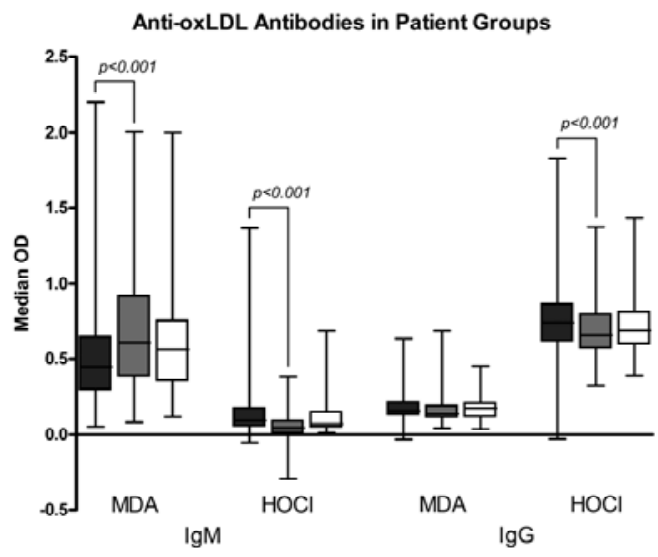

Figure 3.1 Median auto-antibody levels (in netto OD values) with interquartile ranges (wisker bars) in lacunar stroke patients ( $n=158$; dark grey boxes), hypertensives $(n=158$; light grey boxes) and healthy controls ( $n=43$; white boxes). Only significant differences are indicated. 


\section{Discussion}

In the present study we demonstrated that IgM-MDA-oxLDL levels were lower in patients with CSVD, whereas IgG-HOCl-oxLDL were higher in these patients as compared to patients without CSVD. Furthermore, the IgG/IgM-MDA-oxLDL ratio was higher in patients with CSVD. Most interestingly, the only independent predictor for higher IgG-HOCl-oxLDL-levels was a higher number of enlarged Virchow Robin spaces at the level of the basal ganglia. Our data suggest that an autoimmune reaction against oxLDL plays a role in CSVD.

It is unclear whether the immune response against oxLDL is harmful or protective. Our study would be compatible with a differentiated view on the role of oxLDL-antibodies in CSVD, in which IgM-oxLDL antibodies seem to protect from hypertension related vascular damage in the brain (IgM-oxLDL levels are higher in hypertensive patients and patients without SIL; results not corrected for age) whereas the higher levels of IgGoxLDL in lacunar stroke patients, in patients with SIL, as well as the relation between higher IgG-oxLDL and enlarged Virchow Robin spaces (results corrected for age, sex and vascular risk factors), suggest that these antibodies may be involved in the pathogenesis of small vessel damage.

In contrast to our findings with the IgG-HOCl-oxLDL, we consider the differences in IgM-HOCl-oxLDL values, though statistically significant, less relevant, because their concentration as reflected by OD values is fairly low. Low OD values suffer from high background noise and therefore the clinical relevance of these antibodies, at least in CSVD, seems limited.

Our study has several limitations. First, our study design is cross-sectional and therefore the associations we found could as well be an epiphenomenon of CSVD or stroke. Second, we confined patient selection to those with CSVD, as we aimed at the relation between CSVD and oxLDL-antibodies; therefore we cannot exclude that the anti-oxLDL response does not occur in patients with other stroke subtypes. Third, our MRI protocol did not include diffusion weighted imaging to ascertain the presence of an acute, symptomatic lacunar infarct. However, most MR scans in lacunar stroke patients were made several weeks after the stroke, a time frame in which diffusion weighted imaging is not of additional value. Fourth, to further enhance the quality of our anti-oxLDL test we could have used blocking to prevent aspecific antibody binding (though, in our hands background binding was even higher; results not shown) or have used a commercially produced antibody for intra-assay control. However, we suggest that only the use of a capture-ELISA (using a commercially produced antibody as coating to capture oxLDL) could further lead to more specific results of the anti-oxLDL test. Notwithstanding these limitations, the strengths of our study remain that we examined a large group of well characterised patients, and that we excluded the effects of an acute phase response.

In conclusion, our study provides evidence for an autoinflammatory process with oxLDL as a candidate antigen in CSVD. However, further research is needed; results 
from future longitudinal studies as well as from basic research should provide insight into the role which oxLDL-antibodies play in the inflammation which is suspected to contribute to CSVD. 


\section{References}

1. Ross R. Atherosclerosis--an inflammatory disease. N Engl J Med. 1999;340:115-126

2. Farrall AJ, Wardlaw JM. Blood-brain barrier: ageing and microvascular disease - systematic review and meta-analysis. Neurobiol Aging. 2009;30:337-352

3. de Jong G, Kessels F, Lodder J. Two types of lacunar infarcts: further arguments from a study on prognosis. Stroke. 2002;33:2072-2076

4. Henskens LH, Kroon AA, van Oostenbrugge RJ, Gronenschild EH, Fuss-Lejeune MM, Hofman PA, Lodder J, de Leeuw PW. Increased aortic pulse wave velocity is associated with silent cerebral small-vessel disease in hypertensive patients. Hypertension. 2008;52:1120-1126

5. Rouhl RPW, van Oostenbrugge RJ, Knottnerus ILH, Staals JEA, Lodder J. Virchow-Robin spaces relate to cerebral small vessel disease severity. J Neurol. 2008;255:692-696

6. Fazekas F, Chawluk JB, Alavi A, Hurtig HI, Zimmerman RA. MR signal abnormalities at $1.5 \mathrm{~T}$ in Alzheimer's dementia and normal aging. AJR Am J Roentgenol. 1987;149:351-356

7. Slot MC, Theunissen R, van Paassen P, Damoiseaux JG, Cohen Tervaert JW. Anti-oxidized low-density lipoprotein antibodies in myeloperoxidase-positive vasculitis patients preferentially recognize hypochlorite-modified low density lipoproteins. Clin Exp Immunol. 2007;149:257-264 


\section{Chapter 4}

\section{Vascular inflammation in cerebral small vessel disease}

RPW Rouhl

JGMC Damoiseaux

J Lodder

ROMFIH Theunissen

ILH Knottnerus

J Staals

LHG Henskens

AA Kroon

PW de Leeuw

JW Cohen Tervaert

RJ van Oostenbrugge

Neurobiology of Aging

doi:10.1016/j.neurobiolaging.2011.04.008 


\section{Abstract}

\section{Background}

Cerebral small vessel disease (CSVD) is considered to be caused by an increased permeability of the blood brain barrier and results in enlargement of Virchow Robin spaces (VRs), white matter lesions, brain microbleeds and lacunar infarcts. The increased permeability of the blood brain barrier may relate to endothelial cell activation and activated monocytes/macrophages. Therefore, we hypothesized that plasma markers of endothelial activation (adhesion molecules) and monocyte/macrophage activation (neopterin) relate to CSVD manifestations.

\section{Methods}

In 163 first-ever lacunar stroke patients and 183 essential hypertensive patients, we assessed CSVD manifestations on brain MRI and levels of CRP, neopterin, as well as circulating soluble adhesion molecules (sICAM-1, sVCAM-1, sE-selectin, sP-selectin).

\section{Results}

Neopterin, sICAM-1 and SVCAM-1 levels were higher in patients with extensive CSVD manifestations than in those without $(p<0.01)$. Neopterin levels independently related to higher numbers of enlarged VRs $(p<0.001)$.

\section{Conclusion}

An inflammatory process with activated monocytes/macrophages may play a role in the increased permeability of the blood brain barrier in patients with CSVD. 


\section{Introduction}

Cerebral small vessel disease (CSVD) poses major challenges for physicians in the ageing population. CSVD has a high morbidity: it relates to (recurrent) ischemic stroke, ${ }^{1}$ cognitive disturbance ${ }^{2-4}$ and cognitive decline, ${ }^{5,6}$ gait disturbances, ${ }^{7}$ and urinary problems. $^{8}$ CSVD relates to vascular risk factors like increasing age ${ }^{6,9}$ and hypertension. ${ }^{10}$ However, effective therapies to reduce the burden of CSVD are lacking up till now, because the unravelling of the pathophysiological mechanisms leading to CSVD has only just started.

The pathogenesis of CSVD probably starts with an increase in permeability of the blood-brain barrier ${ }^{11}$ with enlargement of Virchow Robin spaces (perivascular spaces), (a)symptomatic lacunar infarcts, white matter lesions (WML) and microbleeds as sequelae. ${ }^{12-14}$ The blood-brain barrier is maintained by the interplay between endothelial cells, pericytes and astrocytes. Endothelial dysfunction could, therefore, lead to an increase in blood-brain barrier permeability. Indeed, in patients with WML, levels of soluble adhesion molecules, like sE-selectin, ${ }^{15}$ intercellular adhesion molecule1 (sICAM-1) ${ }^{16}$ sP-selectin, ${ }^{17}$ and vascular cellular adhesion molecule-1 (sVCAM-1) ${ }^{17}$ which are markers of endothelial dysfunction, ${ }^{18}$ are elevated. However, the cause of the endothelial dysfunction remains unclear.

Adhesion molecules are expressed by endothelial cells in increased amounts on activation. They enable interaction with circulating leukocytes. ${ }^{19}$ In patients with vascular diseases such as atherosclerosis and vasculitis, levels of circulating soluble adhesion molecules are elevated. ${ }^{20,21}$ As a result of the leukocyte-endothelial interactions, both endothelial cells and leukocytes (e.g. monocytes) become increasingly activated..$^{22}$ Activated monocytes/macrophages produce neopterin as well as cytokines which induce liver cells to produce C-reactive protein (CRP). ${ }^{23}$ Neopterin and CRP levels are elevated in patients with vascular disease, and relate to a higher risk of ischemic events. ${ }^{24}$ Furthermore, neopterin may itself induce endothelial dysfunction with increased expression of adhesion molecules as a consequence. ${ }^{25}$

We hypothesized that patients with CSVD have higher levels of neopterin, CRP, and soluble adhesion molecules, than patients without. To test our hypothesis, we selected patients with a high prevalence of CSVD: first-ever lacunar stroke patients as well as essential hypertensive patients.

\section{Patients and methods}

\section{Patients}

Patients included in our study participated in two larger studies, the lacunar stroke patients in a longitudinal study on biological determinants of CSVD, whereas the 
hypertensive patients participated in a study on brain damage in hypertension (HYBRiD).

All 280 first-ever lacunar stroke patients (event between May 2003 and December 2007) who were registered in the prospective Maastricht Stroke Registry were eligible for inclusion in the study. This registry is a hospital based database including all stroke patients over the age of 18 years with symptoms lasting longer than 24 hours. We defined lacunar stroke as an acute stroke syndrome with a lesion on imaging compatible with the occlusion of a single perforating small artery, consisting of a subcortical, demarcated lesion with a diameter $<20 \mathrm{~mm}$ on magnetic resonance imaging (MRI). If no such lesion was visible, we used established clinical criteria for lacunar stroke. ${ }^{1}$ Furthermore, causes other than CSVD (cardiac embolic source, cerebral large vessel disease, carotid stenosis on Duplex imaging), ${ }^{1}$ or history of systemic vasculitis or malignant disease had to be excluded. Altogether, 163 patients were willing and able to participate.

Essential hypertensive patients were recruited from the outpatient department of Internal Medicine. At their inclusion, these patients were free of any symptomatic ischemic or vascular disease, or other comorbidity like atrial fibrillation, chronic renal disease, systemic vasculitis or malignant disease. ${ }^{26}$ Of the 389 eligible patients, 183 were willing and able to participate in the present study.

Forty-three patients who visited the neurological outpatient department with myogenic back pain or entrapment neuropathies served as controls. They had no vascular or inflammatory disease, no hypertension, and no silent ischemic lesions on cerebral MRI.

Vascular risk factor profiles were recorded for all participants. For the lacunar stroke patients, we defined characteristics based on values obtained after the acute phase (at or around 3 months after the stroke). We defined hypertension as known hypertension, treated or not, or at least 2 blood pressure recordings $>140 / 90 \mathrm{mmHg}$; diabetes mellitus as known diabetes, treated or not, or fasting serum glucose $>7 \mathrm{mmol} / \mathrm{L}$, or a postprandial level $>11 \mathrm{mmol} / \mathrm{L}$ on at least 2 separate occasions; coronary artery disease as known or treated angina pectoris, the presence of myocardial infarction, or typical ECG changes; hypercholesterolemia as known high cholesterol levels, treated or known, or fasting total cholesterol levels of $>5.0 \mathrm{mmol} / \mathrm{L}$; and peripheral vascular disease as known intermittent claudication, leg ischemia at rest, or amputation as a consequence of peripheral vascular disease.

\section{Procedures}

To prevent confounding by acute phase responses, all lacunar stroke patients underwent the procedures mentioned below at or around 3 months after their stroke. 


\section{$M R I$ of the brain}

We used 1.5 Tesla imaging with standard T2-weighted, fluid-attenuated inversionrecovery (FLAIR) and gradient echo sequences. ${ }^{27}$ Images were assessed by consensus by two neurovascular researchers (R.P.W. Rouhl and R.J. van Oostenbrugge) as described earlier; ${ }^{28}$ in case of disagreement, the judgement of a third (J. Lodder) was decisive. We counted silent lacunar infarcts (with diameter $<20 \mathrm{~mm}$; hyperintense lesions on T2 imaging with corresponding hypointense lesion with hyperintense rim on FLAIR images) and deep and/or superficial microbleeds (small $(<5 \mathrm{~mm}$ ) hypointensities on gradient echo imaging, not representing calcifications or superficial blood vessels). We used the Fazekas-scale to estimate the extent of the periventricular and deep WML. ${ }^{29}$ Extensive WML were defined as a score of 3 (periventricular hyperintensities with involvement of white matter) on the periventricular scale, and/or a score of 2 or 3 on the deep white matter scale (beginning confluence of lesions or large confluent lesions). Furthermore, we determined another manifestation of cerebral small vessel disease, ${ }^{28}$ namely enlarged Virchow Robin spaces at three different levels (basal ganglia, linear spaces at sella media level, and punctuate spaces at centrum semiovale level). These were assessed for both hemispheres together using a predefined three point scale: 1 ) $<20,2$ ) between 20 and 50 , and 3 ) $>50 . .^{28}$

\section{Blood}

Blood was sampled from an antecubital vein into $5 \mathrm{ml}$ serum as well as $4 \mathrm{ml}$ (EDTA) plasma tubes (BD Biosciences, Breda, the Netherlands). Plasma was separated from the blood cells within 2 hours and stored at $-70^{\circ} \mathrm{C}$ whereas serum was stored at $-20^{\circ} \mathrm{C}$ until analysis.

\section{Measurements of adhesion molecules: sVCAM-1, sICAM-1, sP-selectin, and sE-selectin}

sVCAM-1, sICAM-1, sP-selectin, and sE-selectin were all measured using commercially available ELISA kits (BioSource Europe, Nivelles, Belgium) following manufacturer's instructions. Results are expressed as $\mathrm{ng} / \mathrm{mL}$. Intra-assay variability was $3.1 \%, 4.1 \%$, $2.4 \%$, and $5.4 \%$, whereas inter-assay variability was $5.2 \%, 7.7 \%, 5.2 \%$, and $6.0 \%$ for sVCAM-1, sICAM-1, sP-selectin, and sE-selectin respectively.

\section{Measurement of neopterin and high sensitivity (hs) CRP}

Neopterin was measured using commercially available ELISA kits (IBL Hamburg, Germany), following manufacturer's instructions. Data are expressed as $\mathrm{ng} / \mathrm{mL}$; for this test, intra-assay variability was $3.6 \%$, whereas inter-assay variability was $7.2 \%$. hsCRP was determined with nephelometry, using the BN ProSpec (Siemens, Germany) using a previously described protocol; ${ }^{30}$ data are expressed as $\mathrm{mg} / \mathrm{L}$. Intra-assay variability was $1.4 \%$, and inter-assay variability was $0.9 \%$. 


\section{Statistical analysis}

First, in our primary unadjusted analysis, we compared levels of neopterin, hsCRP, and adhesion molecules (using Mann-Whitney tests) between all patients with or without 1) asymptomatic lacunar infarcts, 2) extensive WML, and 3) both asymptomatic lacunar infarcts in combination with extensive WML. In this analysis, we considered all lacunar stroke patients as well as all hypertensive patients together, which is in line with other studies in CSVD patients (like the LADIS and ARIC-studies), assuming that the pathophysiology of CSVD manifestations is similar, regardless of the underlying disease. $^{31,32}$ In a secondary unadjusted analysis, we considered the lacunar stroke patient group and hypertensive patient group separately. We used values from healthy controls as a reference for 'normal' levels (without testing statistically, as we did not have a hypothesis regarding a difference between patients and controls). We also assessed unadjusted correlations (using Spearman's rho) between the adhesion molecules, hsCRP and neopterin.

Second, in our multivariate analysis we adjusted for possible confounders (age, sex, and vascular risk factor profile). In this analysis we tried to determine whether there were independent relations between adhesion molecules, neopterin or hsCRP on one hand and MRI characteristics of CSVD (asymptomatic lacunar infarcts, extensive white matter lesions, brain microbleeds and enlarged VRs) on the other, using linear regression analysis. We used log-transformation to correct for non-normality of the data (neopterin and the adhesion molecules). Unless indicated otherwise, we considered a p-value $<0.05$ statistically significant. All analyses were performed using SPSS version 16 (Statistical Package for the Social Sciences, Chicago, IL, USA).

\section{Results}

\section{Patient characteristics}

Patient characteristics as well as vascular risk factor profiles are shown in Table 4.1. Of the lacunar stroke patients, 104 had asymptomatic lacunar infarcts, and 59 had extensive WML, whereas of the hypertensive patients 13 had asymptomatic lacunar infarcts, and 22 had extensive WML. As per definition, none of the controls had asymptomatic lacunar infarcts or extensive WML.

\section{Univariate associations between CSVD and adhesion molecules, neopterin, and hsCRP}

In our first, unadjusted, analysis, we compared levels of inflammatory markers and adhesion molecules in patients with or without silent lesions on MR Imaging. As shown in Table 4.2, patients with asymptomatic lacunar infarcts had higher levels of neopterin, sP-selectin, sICAM-1 as well as sVCAM-1 than those without, whereas 
hsCRP and sE-selectin levels did not differ. When we compared patients with extensive WML to those without, the first had higher levels of neopterin and SVCAM-1. When patients with both asymptomatic lacunar infarcts as well as extensive WML were compared to those without both these types of lesions, neopterin, sICAM-1 and sVCAM-1 levels were higher in the first group. Neopterin as well as sVCAM-1 levels were similar in patients without CSVD manifestations as compared to healthy controls. In a second unadjusted analysis, when considering lacunar stroke patients or hypertensive patients separately, only neopterin levels differed between those with or without asymptomatic lacunar infarcts only in patients with lacunar stroke $(p=0.04)$ and not in essentially hypertensive patients $(p=0.10)$.

Table 4.1 Characteristics of lacunar stroke patients, hypertensive patients and controls.

\begin{tabular}{lccc}
\hline & $\begin{array}{c}\text { Lacunar Stroke } \\
\text { Patients }(\mathrm{n}=163)\end{array}$ & $\begin{array}{c}\text { Hypertension } \\
\text { Patients }(\mathrm{n}=183)\end{array}$ & $\begin{array}{c}\text { Controls } \\
(\mathrm{n}=43)\end{array}$ \\
\hline Age (mean (士standard deviation (SD))) & $63.9(12.0)$ & $55.3(11.9)$ & $62.0(7.7)$ \\
Male sex (n (\%)) & $100(61.0)$ & $96(52.5)$ & $20(45.5)$ \\
Hypertension (n (\%)) & $107(65.2)$ & $183(100.0)$ & $0(0.0)$ \\
Coronary artery disease (n (\%)) & $23(14.0)$ & $19(10.4)$ & $0(0.0)$ \\
Peripheral Vascular Disease (n (\%)) & $6(3.7)$ & $4(2.2)$ & $0(0.0)$ \\
Diabetes (n (\%)) & $19(11.6)$ & $6(3.3)$ & $0(0.0)$ \\
Hypercholesterolemia (n (\%)) & $129(78.7)$ & $72(39.3)$ & $10(22.7)$ \\
Current Smoking (n (\%)) & $62(37.8)$ & $35(19.1)$ & $13(30.2)$ \\
Statin Use (n (\%)) & $140(85.4)$ & $69(37.7)$ & $3(6.8)$ \\
Antihypertensive use (n (\%)) & $110(67.1)$ & $163(89.1)$ & $0(0.0)$ \\
\hline
\end{tabular}

\section{Correlations between the different adhesion molecules, neopterin, and hsCRP}

In general, all adhesion molecules, neopterin, and hsCRP correlated significantly with each other, though correlation coefficients are relatively low (Spearman's rhos range from 0.10 to 0.30 ). Only sVCAM-1 and neopterin had a rho of 0.30 , with $p<0.001$.

\section{Multivariate analyses: neopterin and E-selectin independently relate to CSVD manifestations}

We determined significant independent relations between the levels of adhesion molecules, inflammatory markers and CSVD manifestations using linear regression analyses. The only association that remained significant after correction for age, sex, pre-existent large vessel disease (coronary artery disease or peripheral artery disease), as well as patient group (hypertensive or lacunar stroke patient), was that between higher neopterin levels and higher numbers of enlarged Virchow Robin spaces at the level of the basal ganglia $(\beta=0.257 ; p<0.001)$, and that between higher sE-selectin levels and higher number of microbleeds, irrespective of their location (deep or superficial) $(\beta=0.155 ; p=0.045)$. 


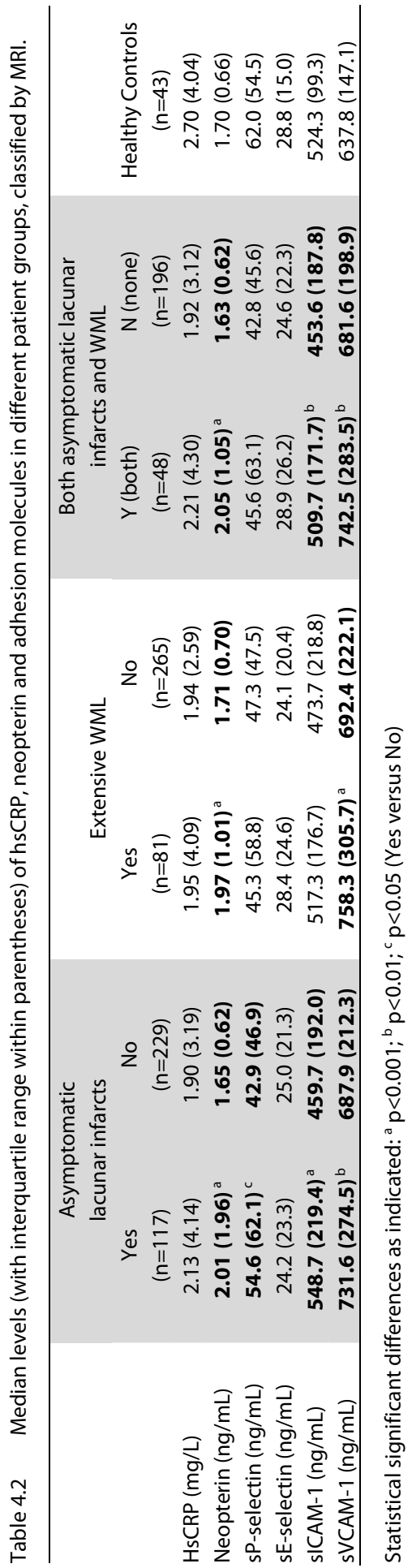




\section{Discussion}

We found higher levels of neopterin in patients with asymptomatic lacunar infarcts as well as in patients with white matter lesions, than in those without these lesions. Furthermore, higher levels of sP-selectin, sE-selectin, and SICAM related to CSVD manifestations. However, most importantly, we found that after correction for vascular risk factors, neopterin levels related independently to higher numbers of enlarged Virchow Robin spaces at the levels of the basal ganglia. As neopterin is a marker of activated monocytes/macrophages our data suggest that activated monocytes/macrophages play a role in the pathophysiology of CSVD.

Limited data are available on neopterin in CSVD. In the acute phase of stroke, neopterin levels increase. ${ }^{33}$ However, there are no data on neopterin in the chronic phase after stroke or in relation to WML. We demonstrated that neopterin levels are higher in lacunar stroke patients than in hypertension patients. Furthermore, we found a relation between higher neopterin levels and higher numbers of enlarged Virchow Robin spaces at the basal ganglia level, which suggests a relation between monocyte/macrophage activation and CSVD. Neopterin is a product of activated monocytes/macrophages and it stimulates both the immune response as well as the endothelium. ${ }^{34}$ Together with other products of activated monocytes/macrophages, neopterin may activate nuclear factor kappa-B, a transcription factor which induces endothelial activation with increased expression of adhesion molecules as a consequence. ${ }^{25}$ Endothelial activation in CSVD could result in increased permeability of the blood brain barrier and induction of an inflammatory reaction, leading to enlargement of the perivascular spaces. Enlargement of the Virchow Robin spaces also coincides with inflammatory activity in multiple sclerosis (as evidenced by contrast enhancing lesions elsewhere in the brain). ${ }^{35}$ Thus, the independent relation between neopterin levels (activated monocytes/macrophages) and number of enlarged Virchow Robin spaces at the basal ganglia level suggests that there may be an inflammatory reaction in CSVD in which activated monocytes/macrophages play a role.

Strikingly, CRP values were not elevated in patients with CSVD manifestations, which contrasts with earlier observations. ${ }^{36}$ CRP is produced in response to interleukin- 6 production by several types of cells among which are monocytes/macrophages. Neopterin, on the other hand, is produced solely by monocytes/macrophages as a result of stimulation by interferon-gamma, which, in turn, is produced by T-cells. ${ }^{37}$ Since we observed a differential upregulation of inflammatory markers, activated Tcells might also be involved in CSVD. Importantly, in our study we avoided the pitfall of known causes for higher neopterin levels: increasing age, autoimmune disease (like ANCA associated vasculitis ${ }^{38}$ ), malignant disease, and infections. ${ }^{23}$ Except for these conditions, neopterin levels are fairly stable over time. ${ }^{24}$

The inflammatory response we found could also relate to endothelial cell activation and dysfunction. Previously, others also demonstrated elevated levels of soluble adhesion molecules in patients with CSVD. In non-diseased subjects, sICAM-1 levels 
related to the extent of WML, independent of hypertension and age. ${ }^{39}$ Furthermore, sICAM-1 levels are elevated after a lacunar stroke, ${ }^{40}$ and higher sICAM-1 levels related to early neurological deterioration and worse outcome at 3 months. ${ }^{41}$ In lacunar stroke patients, sICAM-1 levels were higher in those with WML than in those without. $^{16}$ Moreover, in a community based sample, higher sICAM-1 levels related to progression of WML and lacunar infarcts after 3 and 6 years. ${ }^{42}$ Thus, sICAM- 1 seems to be an important disease marker in lacunar stroke and WML. However, the origin of SICAM-1 is heterogeneous: it may derive from endothelium, but also from activated monocyte/macrophages or from other cells such as smooth muscle cells. ${ }^{43}$ This may be the reason why earlier cross-sectional studies could not unequivocally demonstrate endothelial involvement in CSVD. We confirmed elevated sICAM-1 levels in patients with WML and lacunar infarcts, but unlike the aforementioned studies, we did not find an independent relation between SICAM-1 and manifestations of CSVD. This could be a result of our blood sampling protocol, as we avoided acute phase responses after stroke by postponing blood sampling and excluded patients with concomitant diseases. On the other hand, we found an independent relation between sE-selectin and the number of microbleeds. SE-selectin provides the most valid indication of endothelial involvement, because its source is exclusively endothelial. ${ }^{18}$ Therefore, the independent relation between $\mathrm{SE}$-selectin and the number of microbleeds strongly suggests activation of endothelial cells in CSVD.

Our study has several limitations. First, we confined stroke patient selection to those with lacunar stroke and hypertension, and therefore we are not able to generalize our findings to patients with other causes of stroke (atherothrombotic or cardioembolic) or white matter disease. Second, our study is cross sectional, and therefore no firm conclusions can be drawn with regard to causality. Third, patient selection favoured younger patients in the lacunar stroke group. However, this selection would rather lead to an underestimation of associations. Notwithstanding these limitations, the strengths of our study remain that we studied a large group of well characterized patients, and that we excluded effects of an acute phase response.

In conclusion, our study provides evidence for the involvement of activated monocytes/macrophages in cerebral small vessel disease. Though mechanisms have yet to be determined and our results need confirmation in other populations, this could be relevant for pathophysiological concepts of cerebral small vessel disease and might lead to more effective therapeutic strategies to reduce to burden of CSVD in the ageing population. 


\section{References}

1. de Jong G, Kessels F, Lodder J. Two types of lacunar infarcts: further arguments from a study on prognosis. Stroke. 2002;33:2072-2076

2. Reed BR, Eberling JL, Mungas D, Weiner M, Kramer JH, Jagust WJ. Effects of white matter lesions and lacunes on cortical function. Arch Neurol. 2004;61:1545-1550

3. Wen HM, Mok VC, Fan YH, Lam WW, Tang WK, Wong A, Huang RX, Wong KS. Effect of white matter changes on cognitive impairment in patients with lacunar infarcts. Stroke. 2004;35:1826-1830

4. Tullberg M, Fletcher E, DeCarli C, Mungas D, Reed B, Harvey DJ, Weiner M, Chui HC, Jagust WJ. White matter lesions impair frontal lobe function regardless of their location. Neurology. 2004;63:246-253

5. Garde E, Lykke Mortensen E, Rostrup E, Paulson OB. Decline in intelligence is associated with progression in white matter hyperintensity volume. J Neurol Neurosurg Psychiatry. 2005;76:1289-1291

6. van Dijk EJ, Prins ND, Vrooman HA, Hofman A, Koudstaal PJ, Breteler MM. Progression of cerebral small vessel disease in relation to risk factors and cognitive consequences: Rotterdam Scan study. Stroke. 2008;39:2712-2719

7. Baezner H, Blahak C, Poggesi A, Pantoni L, Inzitari D, Chabriat H, Erkinjuntti T, Fazekas F, Ferro JM, Langhorne P, O'Brien J, Scheltens P, Visser MC, Wahlund LO, Waldemar G, Wallin A, Hennerici MG. Association of gait and balance disorders with age-related white matter changes: the LADIS study. Neurology. 2008;70:935-942

8. Poggesi A, Pracucci G, Chabriat H, Erkinjuntti T, Fazekas F, Verdelho A, Hennerici M, Langhorne $P$, O'Brien J, Scheltens P, Visser MC, Crisby M, Waldemar G, Wallin A, Inzitari D, Pantoni L. Urinary Complaints in Nondisabled Elderly People with Age-Related White Matter Changes: The Leukoaraiosis And DISability (LADIS) Study. J Am Geriatr Soc. 2008;56:1638-1643

9. Wiszniewska M, Devuyst G, Bogousslavsky J, Ghika J, van Melle G. What is the significance of leukoaraiosis in patients with acute ischemic stroke? Arch Neurol. 2000;57:967-973

10. Boiten J, Lodder J, Kessels F. Two clinically distinct lacunar infarct entities? A hypothesis. Stroke. 1993;24:652-656

11. Farrall AJ, Wardlaw JM. Blood-brain barrier: ageing and microvascular disease - systematic review and meta-analysis. Neurobiol Aging. 2009;30:337-352

12. Wardlaw JM, Sandercock PA, Dennis MS, Starr J. Is breakdown of the blood-brain barrier responsible for lacunar stroke, leukoaraiosis, and dementia? Stroke. 2003;34:806-812

13. Rouhl RPW, Van Oostenbrugge RJ, Lodder J. White Matter Lesions: From Present to Future. In: Westland TB, Calton RN, eds. Handbook on White Matter; Structure, Function and Changes. New York: Nova Publishers; 2009:17-28.

14. Vernooij MW, van der Lugt A, Ikram MA, Wielopolski PA, Niessen WJ, Hofman A, Krestin GP, Breteler MM. Prevalence and risk factors of cerebral microbleeds: the Rotterdam Scan Study. Neurology. 2008;70:1208-1214

15. Fassbender K, Bertsch T, Mielke O, Muhlhauser F, Hennerici M. Adhesion molecules in cerebrovascular diseases. Evidence for an inflammatory endothelial activation in cerebral large- and small-vessel disease. Stroke. 1999;30:1647-1650

16. Hassan A, Hunt BJ, O'Sullivan M, Parmar K, Bamford JM, Briley D, Brown MM, Thomas DJ, Markus HS. Markers of endothelial dysfunction in lacunar infarction and ischaemic leukoaraiosis. Brain. 2003; 126:424-432

17. de Leeuw FE, de Kleine M, Frijns CJ, Fijnheer R, van Gijn J, Kappelle LJ. Endothelial cell activation is associated with cerebral white matter lesions in patients with cerebrovascular disease. Ann N Y Acad Sci. 2002;977:306-314

18. Deanfield JE, Halcox JP, Rabelink TJ. Endothelial function and dysfunction: testing and clinical relevance. Circulation. 2007;115:1285-1295

19. Ghosh S, May MJ, Kopp EB. NF-kappa B and Rel proteins: evolutionarily conserved mediators of immune responses. Annu Rev Immunol. 1998;16:225-260

20. Lind L. Circulating markers of inflammation and atherosclerosis. Atherosclerosis. 2003;169:203-214

21. Tervaert JW, Kallenberg CG. Cell adhesion molecules in vasculitis. Curr Opin Rheumatol. 1997;9:16-25

22. Schubert SY, Benarroch A, Monter-Solans J, Edelman ER. Monocyte activation state regulates monocyte-induced endothelial proliferation through Met signaling. Blood. 2010;115:3407-2412 
23. Fuchs D, Weiss G, Reibnegger $\mathrm{G}$, Wachter $\mathrm{H}$. The role of neopterin as a monitor of cellular immune activation in transplantation, inflammatory, infectious, and malignant diseases. Crit Rev Clin Lab Sci. 1992;29:307-341

24. van Haelst PL, Liem A, van Boven AJ, Veeger NJ, van Veldhuisen DJ, Tervaert JW, Gans RO, Zijlstra F. Usefulness of elevated neopterin and C-reactive protein levels in predicting cardiovascular events in patients with non-Q-wave myocardial infarction. Am J Cardiol. 2003;92:1201-1203

25. Cirillo P, Pacileo M, S DER, Calabro P, Gargiulo A, Angri V, Granato-Corigliano F, Fiorentino I, Prevete N, R DEP, Mauro C, Leonardi A, Chiariello M. Neopterin induces pro-atherothrombotic phenotype in human coronary endothelial cells. J Thromb Haemost. 2006;4:2248-2255

26. Henskens LH, Kroon AA, van Oostenbrugge RJ, Gronenschild EH, Fuss-Lejeune MM, Hofman PA, Lodder $\mathrm{J}$, de Leeuw PW. Increased aortic pulse wave velocity is associated with silent cerebral small-vessel disease in hypertensive patients. Hypertension. 2008;52:1120-1126

27. Rouhl RPW, van Oostenbrugge RJ, Damoiseaux JGMC, Debrus-Palmans LL, Theunissen ROMFIH, Knottnerus ILH, Staals JEA, Delanghe JR, Tervaert JW, Lodder J. Haptoglobin phenotype may alter endothelial progenitor cell cluster formation in cerebral small vessel disease. Curr Neurovasc Res. 2009;6:32-41

28. Rouhl RPW, van Oostenbrugge RJ, Knottnerus ILH, Staals JEA, Lodder J. Virchow-Robin spaces relate to cerebral small vessel disease severity. J Neurol. 2008;255:692-696

29. Fazekas F, Chawluk JB, Alavi A, Hurtig HI, Zimmerman RA. MR signal abnormalities at $1.5 \mathrm{~T}$ in Alzheimer's dementia and normal aging. AJR Am J Roentgenol. 1987;149:351-356

30. Rothkrantz-Kos S, Bekers O, Gubbels A, Drent M, Schmitz MP, van Dieijen-Visser MP. Evaluation of two new high-sensitivity methods for C-reactive protein. Ann Clin Biochem. 2003;40:398-405

31. van Straaten EC, Fazekas F, Rostrup E, Scheltens P, Schmidt R, Pantoni L, Inzitari D, Waldemar G, Erkinjuntti T, Mantyla R, Wahlund LO, Barkhof F. Impact of white matter hyperintensities scoring method on correlations with clinical data: the LADIS study. Stroke. 2006;37:836-840

32. Gottesman RF, Coresh J, Catellier DJ, Sharrett AR, Rose KM, Coker LH, Shibata DK, Knopman DS, Jack $\mathrm{CR}$, Mosley TH, Jr. Blood pressure and white-matter disease progression in a biethnic cohort: Atherosclerosis Risk in Communities (ARIC) study. Stroke. 2010;41:3-8

33. Grau AJ, Reis A, Buggle F, Al-Khalaf A, Werle E, Valois N, Bertram M, Becher H, Grond-Ginsbach C. Monocyte function and plasma levels of interleukin-8 in acute ischemic stroke. J Neurol Sci. 2001; 192:41-47

34. Hoffmann G. More on: neopterin induces the proatherothrombotic phenotype in human coronary endothelial cells. J Thromb Haemost. 2007;5:211-212

35. Wuerfel J, Haertle M, Waiczies H, Tysiak E, Bechmann I, Wernecke KD, Zipp F, Paul F. Perivascular spaces--MRI marker of inflammatory activity in the brain? Brain. 2008;131:2332-2340

36. Schmidt R, Schmidt H, Pichler M, Enzinger C, Petrovic K, Niederkorn K, Horner S, Ropele S, Watzinger N, Schumacher M, Berghold A, Kostner GM, Fazekas F. C-reactive protein, carotid atherosclerosis, and cerebral small-vessel disease: results of the Austrian Stroke Prevention Study. Stroke. 2006;37: 2910-2916

37. Schroecksnadel K, Frick B, Winkler C, Fuchs D. Crucial role of interferon-gamma and stimulated macrophages in cardiovascular disease. Curr Vasc Pharmacol. 2006;4:205-213

38. Muller Kobold AC, Kallenberg CG, Tervaert JW. Monocyte activation in patients with Wegener's granulomatosis. Ann Rheum Dis. 1999;58:237-245

39. Han JH, Wong KS, Wang YY, Fu JH, Ding D, Hong Z. Plasma level of sICAM-1 is associated with the extent of white matter lesion among asymptomatic elderly subjects. Clin Neurol Neurosurg. 2009;111: 847-851

40. Knottnerus IL, Ten Cate H, Lodder J, Kessels F, van Oostenbrugge RJ. Endothelial dysfunction in lacunar stroke: a systematic review. Cerebrovasc Dis. 2009;27:519-526

41. Castellanos M, Castillo J, Garcia MM, Leira R, Serena J, Chamorro A, Davalos A. Inflammation-mediated damage in progressing lacunar infarctions: a potential therapeutic target. Stroke. 2002;33:982-987

42. Markus HS, Hunt B, Palmer K, Enzinger C, Schmidt H, Schmidt R. Markers of endothelial and hemostatic activation and progression of cerebral white matter hyperintensities: longitudinal results of the Austrian Stroke Prevention Study. Stroke. 2005;36:1410-1414

43. Constans J, Conri C. Circulating markers of endothelial function in cardiovascular disease. Clin Chim Acta. 2006;368:33-47 


\section{Chapter 5}

\section{Endothelial progenitor cells in cerebrovascular disease}

RPW Rouhl

RJ van Oostenbrugge

JGMC Damoiseaux

JW Cohen Tervaert

J Lodder

Updated from:

Endothelial Progenitor Cell Research in Stroke: A Potential Shift in Pathophysiological and

Therapeutical Concepts. Stroke 2008;39:2158-2165 


\section{Abstract}

Stroke is the leading cause of disability in the Western world; however, few therapies are at hand to decrease this burden. Endothelial progenitor cells (EPC) have been introduced in cardiovascular medicine as factotums. EPC can repair damaged endothelium and attenuate the development and progression of atherosclerosis. Also, EPC can form new vessels in ischemic areas, and thus promote recovery after ischemic events. In stroke, however, EPC research is limited. In our overview, we provide background information on EPC use as a risk marker and as a potential therapeutic agent. In our opinion, the lack of EPC studies in stroke should instigate vascular neurologists to participate in EPC research, as EPC could also change pathophysiological concepts and improve clinical treatments in vascular neurology. 


\section{Introduction}

Endothelial progenitor cells (EPC) are immature endothelial cells which circulate in peripheral blood. These cells were first described by Asahara and colleagues. ${ }^{1}$ In their study, EPC were isolated from human blood and injected into animals with limb ischemia. Subsequently, EPC were found in the endothelium of newly formed vessels in ischemic regions, indicating that there are cells in the human blood which were involved in the formation of new vessels after ischemia.

In another study, Griese and colleagues injected EPC into animals with carotid balloon injury (a model of endothelial damage). After healing of the injury, EPC were found in the recovered endothelium, ${ }^{2}$ indicating that EPC were also involved in the repair of damaged endothelium.

The regenerative potential of EPC suggested by these findings has led to different clinical studies, largely based on the following two hypotheses: 1) Patients with lower EPC numbers are at higher risk for atherosclerotic events, and 2) patients with ischemic events may benefit from EPC administration.

In this chapter, we will elaborate on these two clinical hypotheses and provide background information of EPC characteristics, measurement, and use as a therapeutic agent. We will then focus on EPC in cerebrovascular disease. Unfortunately, most studies which are published up till now are small and performed in animals or highly selected patients. Therefore, results have to be interpreted with caution.

\section{EPC characteristics and measurements}

EPC are maturating cells, derived from immature stem cells. They enter peripheral blood in specific circumstances (see below). They are halfway in their maturation process to become endothelial cells. Therefore, EPC possess functional and structural characteristics of both stem cells and mature endothelial cells (see Table 5.1). During their development, EPC gradually loose stem cell characteristics, and progressively gain endothelial cell characteristics. Consequently, the specific set of characteristics of an EPC on a given time point depends on its degree of maturation. For quantification, EPC must be defined accurately. Therefore, the combination of structural and functional characteristics should be carefully chosen to exclude other immature stem cells or mature endothelial cells.

There are two different quantification techniques. First, cell culture (lower part of Figure 5.1): isolated mononuclear cells from peripheral blood are cultured for several days in conditions which selectively favour growth of EPC. These conditions include coating of plates with macromolecules like gelatine and addition of endothelial growth factors to the culture medium. Therefore, quantification of EPC by culture also depends on the EPC function (EPC have to be viable and to be able to respond to the culture conditions; see Table 5.1). EPC form clusters from the third day on, and these 
clusters are counted after 7 to 28 days. Further testing to confirm the endothelial phenotype of the cells involves uptake of acetylated LDL, binding of Ulex europaeus lectin and binding of specific antibodies. ${ }^{1,3}$

Table 5.1 Characteristics of Stem Cells and Endothelial Cells shared by Endothelial Progenitor Cells ${ }^{4}$.

\begin{tabular}{cc}
\hline Stem Cell Characteristic & Endothelial Cell Characteristic \\
\hline Presence of the Surface molecules & Presence of the Surface molecules CD144, CD146, \\
CD34 and CD133 & von Willebrand factor, and VEGFR-2 \\
Cluster Formation in culture & Response (proliferation) to endothelial \\
Highly Proliferative & growth factors in culture \\
Resistance to Stress & Adhesion to macromolecules \\
& Uptake of acetylated LDL and binding of \\
UEA (Ulex Europaeus Lectin)
\end{tabular}

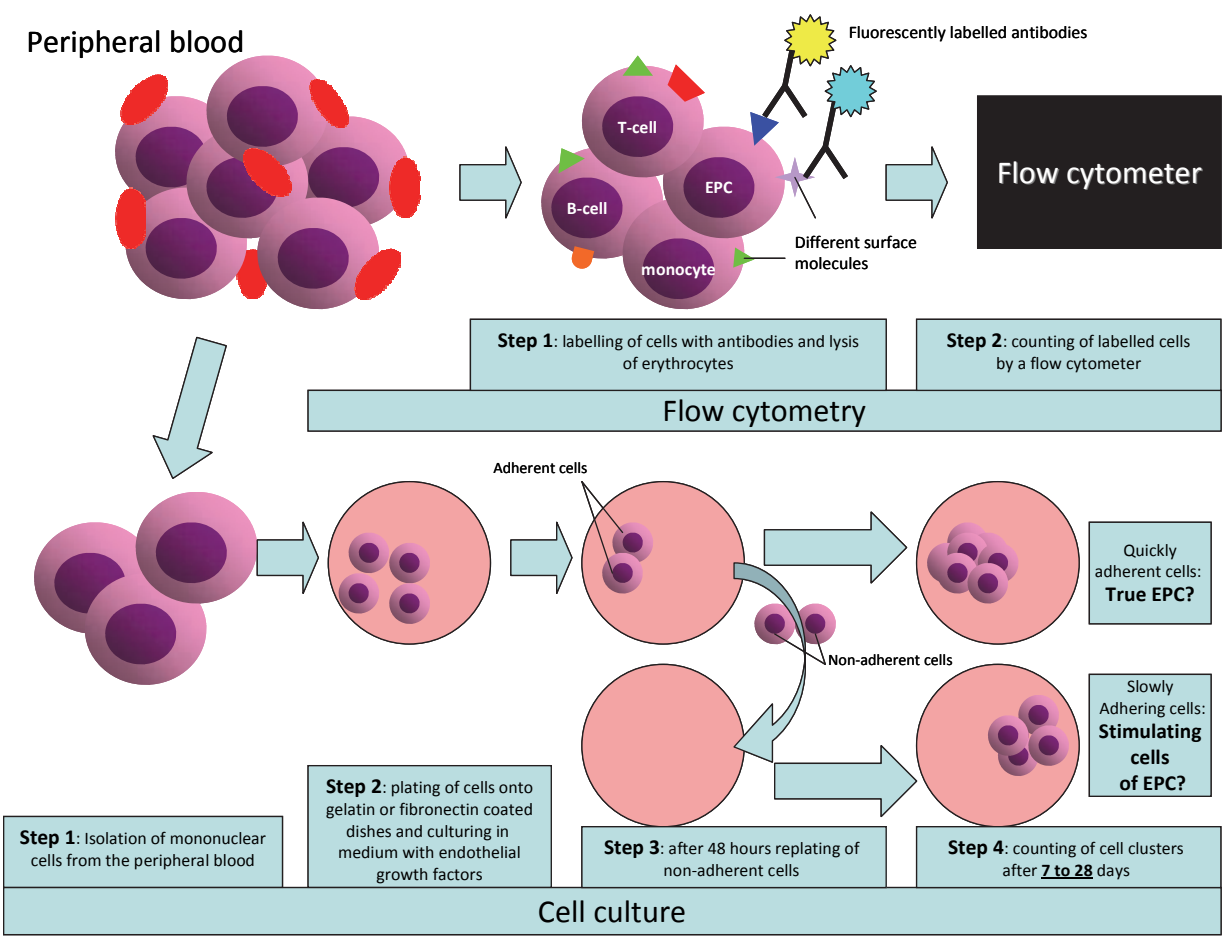

Figure 5.1 Different techniques for the measurement of EPC numbers. 
The second technique is flow cytometry (upper part of Figure 5.1): cells are labelled with fluorescent antibodies to EPC surface antigens (see Table 5.2) and subsequently counted with a flow cytometer. Since EPC are rare in peripheral blood, the noise to signal ratio has to be minimalized by additional measures, ${ }^{5,6}$ otherwise reliable results cannot be obtained. In contrast to culturing, flow cytometry does not depend on EPC function, but directly measures the number of EPC. Because of this difference, results are not exchangeable between the two techniques. ${ }^{7-9}$

Table 5.2 EPC surface markers.

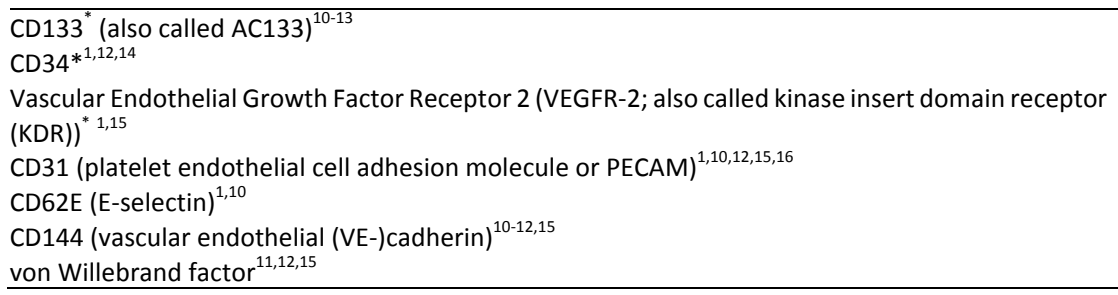

* Most often used for EPC quantification by flow cytometric analysis.

Although both methods are widely used, techniques are not yet standardized. Recently, Yoder et al. ${ }^{17}$ demonstrated that only cells which adhere early in culture (within 48 hours) are true EPC. Only these cells possess endothelial characteristics and ultimately develop into mature endothelial cells. In culture, these cells do not proliferate immediately (only after one to two weeks), and they are also called "late outgrowth EPC" ${ }^{18}$ Cells which adhere later than 48 hours (the non-adherent cells in Figure 5.1) are cells with angiogenic-monocytic characteristics. ${ }^{19}$ These cells promote the functioning and outgrowth of the EPC by production of growth factors, but do not mature into endothelial cells themselves. In culture, these cells proliferate rapidly (after one to two days), and therefore, are also called "early outgrowth EPC". ${ }^{18}$ Thus, in culture, at least two different cell populations have characteristics of EPC, but only the population which adheres within the first 48 hours truly becomes endothelial.

In addition, in flow cytometry, there is also discussion how to control for the low event rate $^{20}$ and how to characterize EPC. Most intriguing question is whether CD34 should be included. Popa et al. ${ }^{21}$ demonstrated that cells with the surface marker CD34 (CD34+) are possibly not true EPC, but only potent regulators of formation of new vessels. These CD34+ cells possibly resemble the late adhering angiogenic cells demonstrated by Yoder et al. ${ }^{17}$ in the culture technique. Furthermore, the process of in vitro vascular tube formation was only enhanced if $\mathrm{CD} 34+$ and $\mathrm{CD} 34$ - cells were cocultured. ${ }^{22}$ Also, injection of CD34+ in combination with CD34- into animals with vascular injury led to more neovascularization than when either cell group alone was administered. ${ }^{23}$ Furthermore, in an experimental hypoxic environment CD34+-cells 
only paracrinely stimulated angiogenesis and also induced a proinflammatory response (chemotaxis of macrophages) and did not incorporate into endothelial layers themselves. ${ }^{24}$ From these studies, we suggest that CD34 potentially is not a crucial marker for EPC.

In conclusion, two techniques are used to quantify EPC. Results from flow cytometric and culture studies are, however, not interchangeable and cannot be interpreted without knowledge of the limitations of these techniques.

\section{EPC in cardiovascular risk assessment}

In two prognostic studies, EPC numbers were found to be related to cardiovascular risk. Werner et al. ${ }^{25}$ followed 519 stable coronary artery disease (CAD) patients for 12 months and found lower EPC numbers (in flow cytometry and in a subgroup in culture) in patients with a cardiovascular event than in event free patients. Schmidt-Lucke et al. $^{26}$ found in 77 stable CAD patients and 43 disease free controls, that lower EPC numbers (in flow cytometry) related to a higher cardiovascular event rate during 10 months follow-up. The independent association of lower EPC number with cardiovascular prognosis strongly suggests that EPC are a risk marker for future cardiovascular events.

Are EPC measurements a more accurate vascular risk assessment than currently used clinico-epidemiological factors? Unfortunately, there are some major caveats. First, EPC quantification is laborious. Second, for both culture and flow cytometric technique neither a golden standard methodology nor an international standard preparation enabling reliable calibration is avaible. ${ }^{3,27,28}$ Third, slight modifications in technique could result in the measurement of different (non-EPC) cell populations. Fourth, results from both techniques are not exchangeable. Fifth, EPC quantification should not be performed shortly after a vascular event, because EPC numbers rise in response to ischemia (see next paragraph). Therefore, EPC numbers in the stable phase could be more important for risk assessment than in an acute phase after a vascular event. Finally, 'normal' values of EPC numbers are unknown. So, we think that implementation of EPC quantification as accurate vascular risk marker in standard medicine will take some time and published EPC studies need confirmation by more research groups.

Furthermore, other questions have to be answered first: 1) does combination of the two EPC quantification techniques result in better risk assessment?, 2) is EPC quantification superior to other methods of risk assessment using high sensitivity CReactive Protein and/or Intima-Media Thickness measurements?, and 3) is there a pathophysiological mechanism behind the association between lower numbers of EPC and a higher cardiovascular risk? Finally, it is pivotal to know whether an increase of low EPC numbers will also result in reduction of cardiovascular events. Until these 
questions are answered, EPC measurement for vascular risk assessment will not be routinely performed in cardiovascular patients.

\section{EPC biology and atherosclerosis}

The nature of the association between lower EPC numbers and increased risk for cardiovascular events $^{29}$ remains speculative. Generally, it is interpreted as a causal one. Because EPC offspring is present in restored endothelium, ${ }^{2,30-32}$ EPC are thought to repair damaged endothelium. Damaged endothelium is, next to ischemia, responsible for EPC recruitment from the bone marrow (see Figure 5.2). Proinflammatory cytokines, granulocyte-colony stimulating factor, erythropoietin, and apoptotic bodies from endothelial cells all stimulate the release of EPC into the circulation. ${ }^{3,4}$ Thus, in an acute stage after a vascular event, EPC numbers rise.

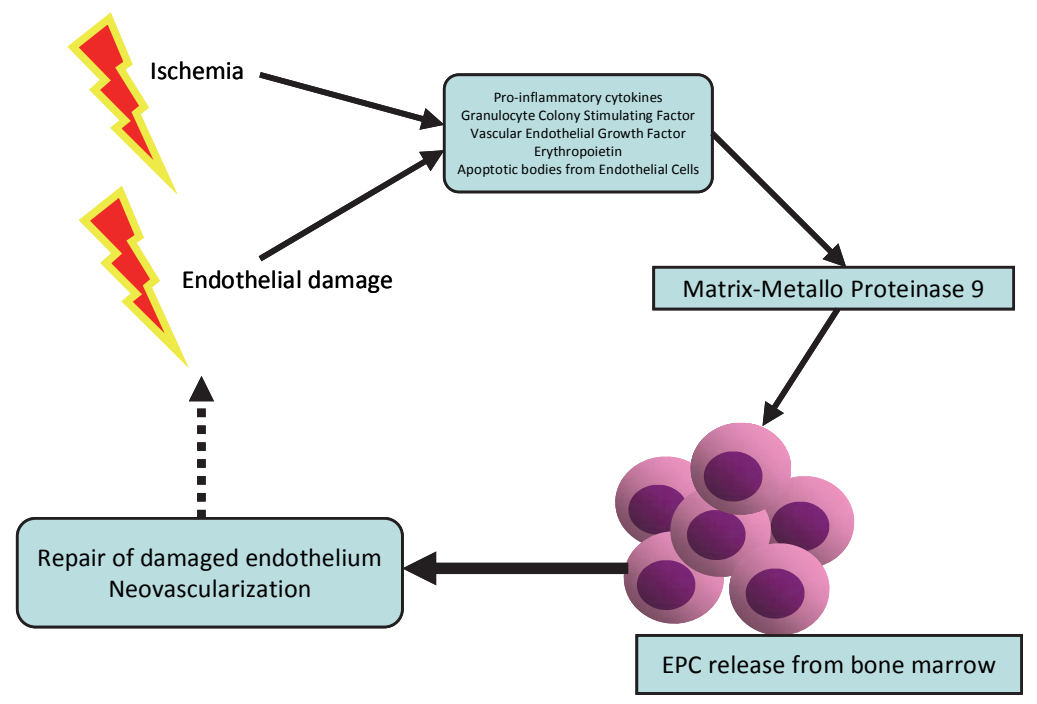

Figure $5.2 \quad$ Biological role of EPC. ${ }^{10,33-55}$

In a stable clinical condition, EPC numbers are influenced by several factors (See Figure 5.3). Interestingly, lower EPC numbers relate to several different atherosclerotic risk factors. It is, therefore, generally assumed that lower EPC numbers reflect a higher consumption of EPC for restoration of endothelial damage. Indeed, in patients with active vasculitis, a disease with wide-spread endothelial damage, very low EPC numbers are found. ${ }^{56}$ Damaged endothelium plays a role in atherosclerotic lesion formation and progression; it stimulates a pro-atherogenic inflammatory response, mediated by monocytes, macrophages and T-cells. ${ }^{57}$ EPC numbers could therefore be lower as a consequence of a higher consumption, and run relatively short on restoring the damaged endothelium with consequent atherosclerosis and cardiovascular events. 


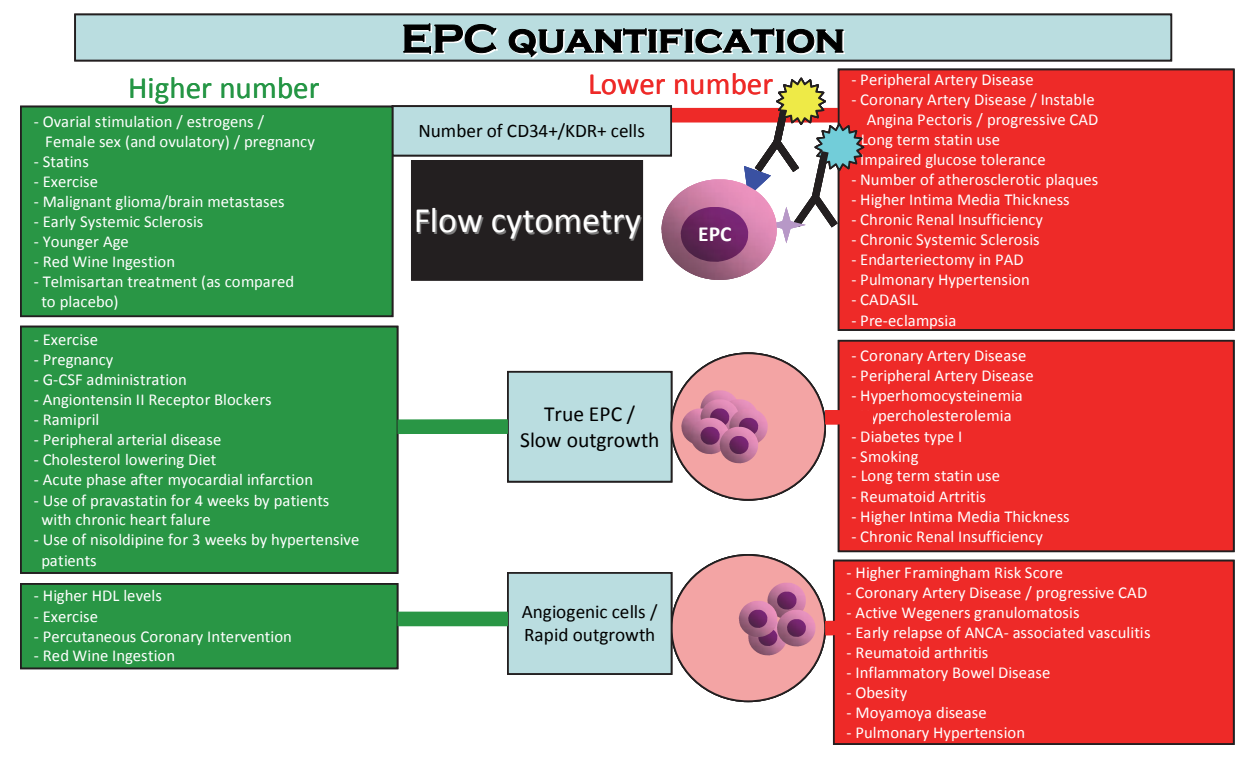

EPC FUNCTIONAL TESTING

Beneficial effect Adverse effect

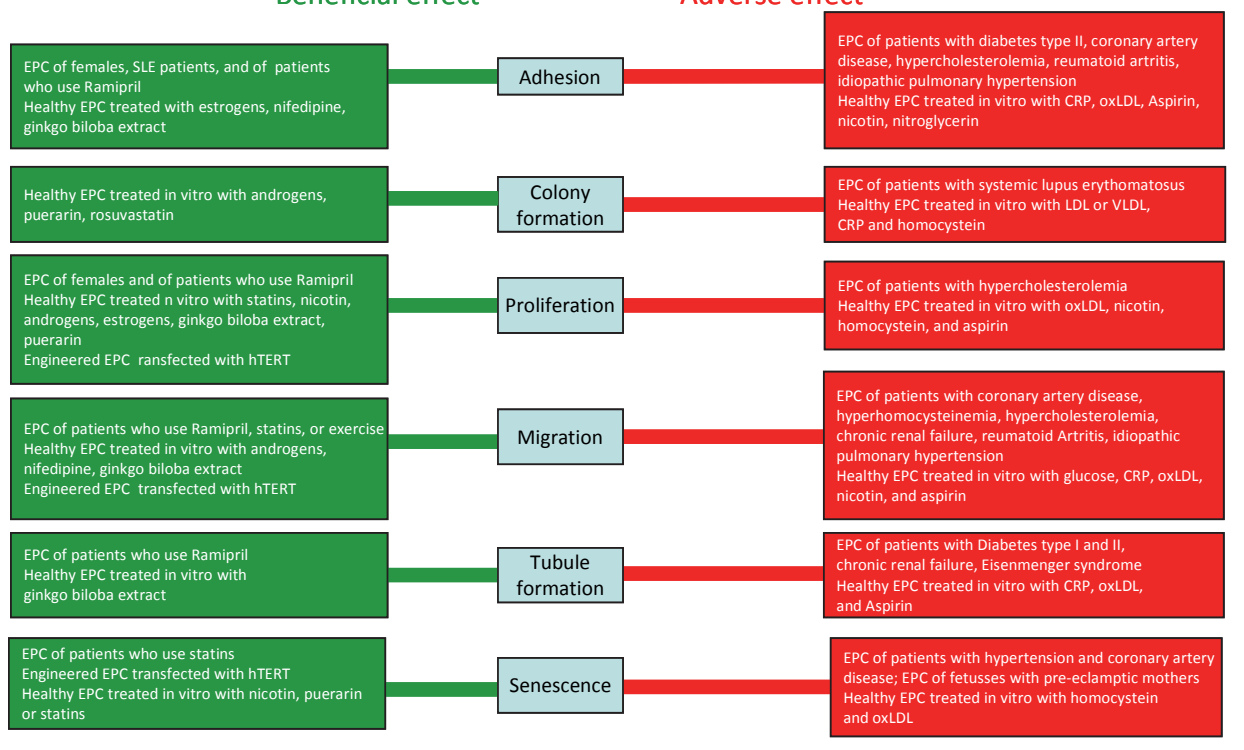

Figure 5.3 Measurement results in literature. ${ }^{26,29,52,54,56,58-128}$ Note that most data result from small clinical studies in up to 40 strongly selected subjects. TERT=Telomerase Reverse Transcriptase. 
Moreover, not only the number of EPC is related to cardiovascular risk factors but also a disturbed EPC function. ${ }^{129}$ This association between lower results on functional EPC tests (see Figure 5.3) and atherosclerotic risk factors suggests a disturbance in the EPC itself. However, in a recent population based study in 542 subjects higher EPC numbers (counted after 5 days in culture) correlated with lower age and use of cardiovascular drugs. Higher EPC numbers were found in subjects with higher Framingham Risk Scores. ${ }^{130}$ This seems to reject the hypothesis that life style and cardiovascular risk factors (indirectly) deplete the EPC resources. However, these results may be explained by a lower expression of risk factors in the study population due to the subject selection procedure. Possibly, the result even reflects the healthy status of the participants with a higher potential of EPC production as appropriate compensation mechanism. The authors do not present flow cytometric data; absolute numbers of EPC (CD34+/KDR+-cells) could be lower in patients at higher risk, whereas their EPC cluster formation capacities is retained or perhaps even upregulated.

So, although the nature of the association between EPC and atherosclerosis remains speculative, there is ample evidence suggesting a causal relation.

\section{EPC in vasculogenesis}

Asahara et al. found injected EPC in the endothelium of newly formed vessels in previously ischemic animal limbs. ${ }^{1}$ In other animal experiments, EPC administration also resulted in increased blood flow in ischemic zones and a decrease in limb loss. ${ }^{15,55,}$ 131 In experimental cardiac ischemia, administration of progenitor cells (in general) resulted in neovascularization, and reduction of the infarcted area, although the involved mechanisms remain a matter of debate. ${ }^{132,133}$

In humans, use of EPC-based therapy during or after ischemia might be hazardous, because EPC are very similar to haematopoietic progenitor cells, ${ }^{134,135}$ and could, therefore, differentiate into monocytes and macrophages. These cells might aggravate ischemia by increasing the ischemic inflammatory response. A safety study in 20 patients with acute myocardial infarction who received EPC transfusion ${ }^{136}$ addressed this issue, and found that the levels of inflammatory markers (CRP and leukocytes) and levels of troponin $T$ (a marker for cardiac ischemia) did not differ from levels in controls four days after the intervention. In 34 EPC treated CAD patients (TOPCARECHD study) ${ }^{137}$, five major cardiovascular events occurred in the intervention group, as compared to three events in the control group $(n=23)$. Thus, in these small numbers of patients, EPC neither seem to stimulate the inflammatory response, nor increase ischemia. EPC administration might be practiced safely, without EPC therapy related adverse events, though safety data from larger randomized trials are still needed.

But do higher EPC numbers indeed reverse the consequences of ischemia and improve prognosis? In observational studies in patients with myocardial infarction, higher numbers of EPC indeed relate to a better prognosis, more myocardial salvage, ${ }^{138}$ 
viability and perfusion (as measured by positron emission tomography (PET) and single photon emission computed tomography (SPECT) studies ${ }^{139}$ ), and more collaterals in the ischemic zone. ${ }^{84,89}$ Therefore, several investigators planned randomized clinical trials on progenitor cell (PC) administration (among which are EPC) in CAD. Studies differ, however, on various points: 1) the source of PC (bone marrow or blood; with, or without purification), 2) the use of autologous cells or allogenic donor cells, and 3) the method of administration (intravenously or intracoronary infusion).

Randomized clinical trials in CAD patients show a relation between PC administration and improved left ventricular function, mainly on the short term. ${ }^{140}$ In chronic ischemic heart failure, however, effects on change in left ventricular function differ from positive to indifferent. ${ }^{141}$ Randomized trials have also been performed in patients with peripheral artery disease. These studies found that PC administration improved endothelium-dependent vasodilation, ${ }^{142}$ ankle brachial index, rest pain and pain-free walking time. ${ }^{143}$ However, results are not as positive as those in animals, which is possibly due to a higher functional potential of animal EPC. Direct comparative studies between animal and human EPC, though, are lacking. Also, in all studies in patients with coronary or peripheral artery disease, bone marrow cells seem superior to purified EPC. ${ }^{140}$ This is possibly due to the presence of 'contamination' with angiogenic cells in this population, thus to the mutual stimulation of CD34- and CD34+-cells, which is not present in purified EPC (mostly only CD34+-cells). Furthermore, in vivo studies in animals show that adult peripheral blood EPC (cultured clusters) are inferior with regard to formation of new blood vessels (capillary network) to umbilical cord blood EPC. $^{144}$

\section{EPC as risk marker in stroke}

Neurovascular research on EPC is limited until now. Research groups use both previously described techniques, however, seldomly next to each other. Using flow cytometry, Taguchi et al. ${ }^{145}$ measured CD34+-cells in 25 patients with an ischemic stroke. They found peak values after 7 days, and values similar to baseline (as measured shortly after stroke) after 30 days. These findings were replicated later by Machalinski et al. ${ }^{146}$ Also, higher CD34+-cell-levels at 30 days related to higher numbers of infarcts on Magnetic Resonance Imaging and also to cerebrovascular function as measured with PET scanning (cerebral metabolic rate of oxygen, and cerebral blood flow). ${ }^{145}$ Yip et al. ${ }^{147}$ demonstrated an early rise of CD34/KDR+-cells 2 days after stroke. An initially low CD34/KDR+- percentage also related to a poorer neurological prognosis at 90 days, though effect sizes remain obscure as the presentation of data does not allow conclusions on effect sizes. In contrast, Cesari et al. reported no correlations between CD34/KDR+-cells at the time of stroke and three months' outcome ${ }^{148}$ (though they found lower CD34/CD133+-cell numbers (which are hematopoietic progenitor cells) to be related to larger infarct sizes and higher NIHSSscores at admission, with also consequently a relation to outcome which was not 
significant after correction for the NIHSS-score at admission). Also, Bogoslovsky et al. ${ }^{149}$ found that lower numbers of CD34/C133+-cells as well as CD34/CD133/KDR+cells cells related to a larger infarct size. However, in the latter study, sample size is small (17 patients only) and correction for potential confounders is not possible. With regard to the culture technique, Ghani et al. ${ }^{150}$ reported a decreased number of clusters of rapidly adhering cells after stroke and in 'stable cerebrovascular disease', compared to controls free of vascular disease. Higher age and the presence of cerebrovascular disease in general independently related to lower EPC numbers. Unfortunately, the authors did not match controls for age. Chu et al. ${ }^{151}$ replicated the findings of the latter study with a different culture technique (cells were left to adhere for 7 days, which leaves no room for differentiation between early or late outgrowth EPC). Furthermore, they found that cluster numbers were lower in patients with large or small vessel stroke as compared to patients with cardioembolic stroke. However, the absolute EPC number was not assessed and it is therefore unknown whether cluster numbers were lower as a consequence of lower absolute numbers or as a consequence of defective EPC function.

For future studies on the role of EPC in stroke, several caveats have to be borne in mind. First, general recommendations (like basing sample sizes on appropriate power calculations, correction for possible confounders (see Figure 5.3), and the inclusion of healthy controls ${ }^{152}$ ), have to be fulfilled. Second, the laboratory technique of EPC quantification should be standardized as much as possible. Since there is no standard protocol at hand, one single method, preferably after discussion with an experienced centre in EPC research, should be chosen. Also, the timing of blood sampling (directly after the stroke or in a stable phase) should be considered, as values in the acute stage could differ from those in a chronic phase. Third, and probably most important, different stroke causes have to be distinguished, because endothelial involvement in the pathogenesis of different forms of stroke could be different. EPC may be considered as a marker for endothelial involvement. In atherosclerotic ischemic stroke the pathogenesis of the vascular occlusion is more or less similar to that in coronary and peripheral artery disease. Therefore, EPC could be a marker of future events in atherosclerotic stroke and a marker of the endothelial repair mechanism. Cardioembolic stroke though has a different pathogenesis (with different endothelial involvement), and consequently EPC quantification may be less significant as a risk marker. EPC might also differentiate between endothelially mediated and nonendothelially mediated causes of stroke (see Chu et al. ${ }^{151}$ ).

\section{EPC as therapeutic agent in stroke}

Up till now, studies on EPC as a therapeutic agent have only been reported in animal stroke models. A variety of human cell types (neural stem cells, immortalized neural cell lines, and hematopoietic progenitor cells) have already been tested in animals. ${ }^{153}$ Use of cells derived from peripheral blood or bone marrow, among which are the EPC, 
has two main advantages above the other cell types. First it avoids ethical limitations (because there is no need to work with fetal or embryonic tissue). Second, there is a host of experience on use of haematopoeitic progenitor cells in hemato-oncology, and therefore a lot is known about tolerability and side effects of treatment.

In an observational study in mice, higher EPC numbers related to physical exercise, a better functional motor outcome after middle cerebral artery occlusion, increased neovascularization and enhanced blood flow in ischemic zones. ${ }^{154}$ In 48 stroke patients, Sobrino et al. ${ }^{155}$ demonstrated that an observed increase of EPC cluster numbers 7 and 90 days after a stroke also related to a good functional outcome. This rise in EPC number could be due to the release of vascular endothelial growth factor (VEGF; which relates to the size of the infarct). ${ }^{156}$ Higher VEGF levels also relate to better functional outcome. ${ }^{156}$ Experimental administration of EPC in animals furthermore induces an increase in the formation of new blood vessels ${ }^{157}$ and also of blood flow in cerebral ischemia. ${ }^{158}$ However, few transplanted cells are actually found in the brain, ${ }^{153}$ and these cells are only infrequently of endothelial phenotype. ${ }^{159}$

Does this formation of new vessels result in a better stroke recovery? Other neovascularization stimulating agents (like VEGF and other growth factors) administered several days after stroke potentially improve outcome by decreasing the ischemic penumbra. ${ }^{160}$ Importantly, however, these agents also cause an increase in endothelial permeability resulting in brain edema. ${ }^{160}$ Neovascularization thus seems important in recovery, but the adverse effects of neovascularization stimulating agents cause some concern. Whether neovascularization by EPC improves stroke outcome is not known, though EPC could be a valuable alternative for neovascularization stimulating agents. ${ }^{161}$ Furthermore, the beneficial effects of EPC in the brain are probably not limited to neovascularization. In an observational study in rats with experimental stroke, neovascularization related to neurogenesis, which occurs after stroke from neural progenitor cells present in the brain, ${ }^{162}$ and also to migration of these neural progenitor cells along the newly formed vessels. ${ }^{163}$ These processes are tightly linked, as also evidenced by in vitro studies: soluble factors produced by endothelial cells regulate proliferation of neuronal progenitor cells and cell-cell contact between the two cell types regulates differentiation. ${ }^{164}$ Of the soluble factors, VEGF plays a regulating role in this process of neurogenesis and angiogenesis in the brain. ${ }^{165}$ After experimental progenitor cell administration in rats, VEGF levels were higher in the ischemic border zone, ${ }^{166}$ whereas neurogenesis and angiogenesis were reciprocally increased in this zone. ${ }^{167}$ Thus, administered (endothelial) progenitor cells may enhance the proliferation of endogenous neuronal progenitor cells in the brain. Other important substances in this process are eNOS, the enzyme which produces nitric oxide in endothelial cells, as it both regulates angiogenesis and neurogenesis, among others by regulating the secretion of brain derived neurotrophic factor (BDNF) ${ }^{168}$, as well as erythropoietin, which stimulates VEGF and BDNF and thus angiogenesis and neurogenesis ${ }^{169,170}$ (see also Zhang et al. $^{171}$ for review). Next to this paracrine stimulation of neurogenesis, progenitor cells may also adapt neural characteristics 
themselves. However, in animal experiments incorporation into neuronal circuits of these cells seemed unlikely. ${ }^{172}$ The combined pathway of angiogenesis and neurogenesis could be more important than angiogenesis on its own, as the EPC induced vessels are those of small calibre (capillaries), insufficient to restore large perfusion defects. ${ }^{173}$ Independent from the possible mechanism of action, the intravenous administration of human umbilical cord blood (a rich source of various progenitor cells, among which are EPC), ${ }^{174,175} \mathrm{CD} 133+$ +cells, ${ }^{176}$ or even mesenchymal progenitor cells (harvested from adipose tissue and cultured to induce a neural phenotype $)^{177,178}$ led to better recovery of motor function in rats.

There are more potential benefits of EPC for patients with cerebrovascular disease. Next to the potential effects of EPC in acute cerebral ischemia, EPC could be of benefit for patients with leukoaraiosis and vascular dementia. In endothelial cells that are found in white matter lesion vessels, markers of endothelial and microglial activation and immunoreactivity to hypoxia-inducible factors are elevated. ${ }^{179}$ All these changes relate to a chronic hypoxic state. Also, endothelial injury and breakdown of the bloodbrain barrier have been implicated in the pathogenesis of leukoaraiosis and dementia. ${ }^{180}$ In an animal model of retinal small vessel disease, a disease probably very similar to cerebral small vessel disease, healthy EPC (in contrast to diabetic) incorporated into the damaged vessels. ${ }^{181}$ Therefore, EPC might reverse the hypoxic state by neovascularization and restore the endothelial injury and in these two ways prevent the progression of leukoaraiosis.

There is some evidence that suggests that EPC are involved in attenuating the progression of leukoaraiosis. Patients who take Angiotensin I Converting Enzyme (ACE)-inhibitors, which increase circulating EPC numbers, show less progression of white matter lesions in the PROGRESS study. ${ }^{182}$ Of course, this effect could also be due to a blood pressure lowering effect. Since EPC numbers were not measured in this study, we are uncertain what caused the effect on the progression.

Should clinical trials on EPC injection in cerebrovascular disease be started? EPC seem safe in cardiac studies, but cerebral vessels and cerebral ischemia react differently, as also evidenced by the potentially deleterious brain edema in studies that enhanced cerebral neovascularization with VEGF. ${ }^{160}$ Furthermore, the role of EPC in the pathophysiology of cerebrovascular disease is no more than speculative at present. Therefore, it seems wise to plan more studies on the role of EPC in different forms of stroke, before planning clinical trials with EPC injection. In addition, several points need to be clarified before clinical studies can be started, like the time point of transplantation, the cerebral lesions which are fit for EPC treatment, the route and site of cell delivery and the monitoring of the recovery. ${ }^{153}$ Other methods to increase EPC numbers, like drugs (statins, ACE-inhibitors, Angiotensin Receptor Blockers and erythropoietin) or growth factors which stimulate EPC release from the bone marrow, perhaps also deserve attention. 


\section{Conclusion}

In conclusion, EPC hold great promise in cardiovascular medicine, both as a marker for an increased cardiovascular risk and as a therapeutic agent. However, as knowledge on EPC grows, finetuning is needed on all aspects, from basic science to clinical practice, to obtain the best possible results. The lack of EPC studies in stroke should instigate vascular neurologists to participate in this interesting line of research, as EPC could also change pathophysiological and therapeutical concepts, which will hopefully improve clinical treatments in vascular neurology. 


\section{References}

1. Asahara T, Murohara T, Sullivan A, Silver M, van der Zee R, Li T, Witzenbichler B, Schatteman G, Isner JM. Isolation of putative progenitor endothelial cells for angiogenesis. Science. 1997;275:964-967

2. Griese DP, Ehsan A, Melo LG, Kong D, Zhang L, Mann MJ, Pratt RE, Mulligan RC, Dzau VJ. Isolation and transplantation of autologous circulating endothelial cells into denuded vessels and prosthetic grafts: implications for cell-based vascular therapy. Circulation. 2003;108:2710-2715

3. Hristov M, Erl W, Weber PC. Endothelial progenitor cells: mobilization, differentiation, and homing. Arterioscler Thromb Vasc Biol. 2003;23:1185-1189

4. Urbich C, Dimmeler S. Endothelial progenitor cells: characterization and role in vascular biology. Circ Res. 2004;95:343-353

5. Khan SS, Solomon MA, McCoy JP, Jr. Detection of circulating endothelial cells and endothelial progenitor cells by flow cytometry. Cytometry B Clin Cytom. 2005;64:1-8

6. Hristov M, Schmitz S, Schuhmann C, Leyendecker T, von Hundelshausen P, Krotz F, Sohn HY, Nauwelaers FA, Weber C. An optimized flow cytometry protocol for analysis of angiogenic monocytes and endothelial progenitor cells in peripheral blood. Cytometry A. 2009;75:848-853

7. George J, Shmilovich H, Deutsch V, Miller H, Keren G, Roth A. Comparative analysis of methods for assessment of circulating endothelial progenitor cells. Tissue Eng. 2006;12:331-335

8. Shantsila E, Watson T, Tse HF, Lip GY. Endothelial colony forming units: Are they a reliable marker of endothelial progenitor cell numbers? Ann Med. 2007;39:474-479

9. Tura O, Barclay GR, Roddie H, Davies J, Turner ML. Absence of a relationship between immunophenotypic and colony enumeration analysis of endothelial progenitor cells in clinical haematopoietic cell sources. J Trans/ Med. 2007;5:37

10. Peichev M, Naiyer AJ, Pereira D, Zhu Z, Lane WJ, Williams M, Oz MC, Hicklin DJ, Witte L, Moore MA, Rafii S. Expression of VEGFR-2 and AC133 by circulating human CD34(+) cells identifies a population of functional endothelial precursors. Blood. 2000;95:952-958

11. Quirici N, Soligo D, Caneva L, Servida F, Bossolasco P, Deliliers GL. Differentiation and expansion of endothelial cells from human bone marrow CD133(+) cells. Br J Haematol. 2001;115:186-194

12. Reyes M, Dudek A, Jahagirdar B, Koodie L, Marker PH, Verfaillie CM. Origin of endothelial progenitors in human postnatal bone marrow. J Clin Invest. 2002;109:337-346

13. Yin AH, Miraglia S, Zanjani ED, Almeida-Porada G, Ogawa M, Leary AG, Olweus J, Kearney J, Buck DW. AC133, a novel marker for human hematopoietic stem and progenitor cells. Blood. 1997;90:5002-5012

14. Gehling UM, Ergun S, Schumacher U, Wagener C, Pantel K, Otte M, Schuch G, Schafhausen P, Mende T, Kilic N, Kluge K, Schafer B, Hossfeld DK, Fiedler W. In vitro differentiation of endothelial cells from AC133-positive progenitor cells. Blood. 2000;95:3106-3112

15. Murohara T, Ikeda H, Duan J, Shintani S, Sasaki K, Eguchi H, Onitsuka I, Matsui K, Imaizumi T. Transplanted cord blood-derived endothelial precursor cells augment postnatal neovascularization. $J$ Clin Invest. 2000;105:1527-1536

16. Boyer M, Townsend LE, Vogel LM, Falk J, Reitz-Vick D, Trevor KT, Villalba M, Bendick PJ, Glover JL. Isolation of endothelial cells and their progenitor cells from human peripheral blood. J Vasc Surg. 2000;31:181-189

17. Yoder MC, Mead LE, Prater D, Krier TR, Mroueh KN, Li F, Krasich R, Temm CJ, Prchal JT, Ingram DA. Redefining endothelial progenitor cells via clonal analysis and hematopoietic stem/progenitor cell principals. Blood. 2007;109:1801-1809

18. Young PP, Vaughan DE, Hatzopoulos AK. Biologic Properties of Endothelial Progenitor Cells and Their Potential for Cell Therapy. Prog Cardiovasc Dis. 2007;49:421-429

19. Zhang SJ, Zhang H, Wei YJ, Su WJ, Liao ZK, Hou M, Zhou JY, Hu SS. Adult endothelial progenitor cells from human peripheral blood maintain monocyte/macrophage function throughout in vitro culture. Cell Res. 2006;16:577-584

20. Van Craenenbroeck EM, Conraads VM, Van Bockstaele DR, Haine SE, Vermeulen K, Van Tendeloo VF, Vrints CJ, Hoymans VY. Quantification of circulating endothelial progenitor cells: a methodological comparison of six flow cytometric approaches. J Immunol Methods. 2008;332:31-40 
21. Popa ER, Harmsen MC, Tio RA, van der Strate BW, Brouwer LA, Schipper M, Koerts J, De Jongste MJ, Hazenberg A, Hendriks M, van Luyn MJ. Circulating CD34+ progenitor cells modulate host angiogenesis and inflammation in vivo. J Mol Cell Cardiol. 2006;41:86-96

22. Rookmaaker MB, Verhaar MC, Loomans CJ, Verloop R, Peters E, Westerweel PE, Murohara T, Staal FJ, van Zonneveld AJ, Koolwijk P, Rabelink TJ, van Hinsbergh VW. CD34+ cells home, proliferate, and participate in capillary formation, and in combination with CD34- cells enhance tube formation in a 3dimensional matrix. Arterioscler Thromb Vasc Biol. 2005;25:1843-1850

23. Harraz M, Jiao C, Hanlon HD, Hartley RS, Schatteman GC. CD34- blood-derived human endothelial cell progenitors. Stem Cells. 2001;19:304-312

24. van der Strate BW, Popa ER, Schipper M, Brouwer LA, Hendriks M, Harmsen MC, van Luyn MJ. Circulating human $\mathrm{CD} 34+$ progenitor cells modulate neovascularization and inflammation in a nude mouse model. J Mol Cell Cardiol. 2007;42:1086-1097

25. Werner N, Kosiol S, Schiegl T, Ahlers P, Walenta K, Link A, Bohm M, Nickenig G. Circulating endothelial progenitor cells and cardiovascular outcomes. N Engl J Med. 2005;353:999-1007

26. Schmidt-Lucke C, Rossig L, Fichtlscherer S, Vasa M, Britten M, Kamper U, Dimmeler S, Zeiher AM. Reduced number of circulating endothelial progenitor cells predicts future cardiovascular events: proof of concept for the clinical importance of endogenous vascular repair. Circulation. 2005;111: 2981-2987

27. Hristov M, Erl W, Weber PC. Endothelial progenitor cells: isolation and characterization. Trends Cardiovasc Med. 2003;13:201-206

28. Xu QB. Endothelial progenitor cells in angiogenesis. Sheng Li Xue Bao. 2005;57:1-6

29. Hill JM, Zalos G, Halcox JP, Schenke WH, Waclawiw MA, Quyyumi AA, Finkel T. Circulating endothelial progenitor cells, vascular function, and cardiovascular risk. N Engl J Med. 2003;348:593-600

30. Walter DH, Rittig K, Bahlmann FH, Kirchmair R, Silver M, Murayama T, Nishimura H, Losordo DW, Asahara T, Isner JM. Statin therapy accelerates reendothelialization: a novel effect involving mobilization and incorporation of bone marrow-derived endothelial progenitor cells. Circulation. 2002;105:3017-3024

31. Werner N, Junk S, Laufs U, Link A, Walenta K, Bohm M, Nickenig G. Intravenous transfusion of endothelial progenitor cells reduces neointima formation after vascular injury. Circ Res. 2003;93: e17-24

32. Fujiyama S, Amano K, Uehira K, Yoshida M, Nishiwaki Y, Nozawa Y, Jin D, Takai S, Miyazaki M, Egashira $\mathrm{K}$, Imada T, Iwasaka T, Matsubara H. Bone marrow monocyte lineage cells adhere on injured endothelium in a monocyte chemoattractant protein-1-dependent manner and accelerate reendothelialization as endothelial progenitor cells. Circ Res. 2003;93:980-989

33. Luttun A, Carmeliet G, Carmeliet P. Vascular progenitors: from biology to treatment. Trends CardiovasC Med. 2002;12:88-96

34. Takahashi T, Kalka C, Masuda H, Chen D, Silver M, Kearney M, Magner M, Isner JM, Asahara T. Ischemia- and cytokine-induced mobilization of bone marrow-derived endothelial progenitor cells for neovascularization. Nat Med. 1999;5:434-438

35. Heissig B, Hattori K, Dias S, Friedrich M, Ferris B, Hackett NR, Crystal RG, Besmer P, Lyden D, Moore MA, Werb Z, Rafii S. Recruitment of stem and progenitor cells from the bone marrow niche requires MMP-9 mediated release of kit-ligand. Cell. 2002;109:625-637

36. Heeschen C, Aicher A, Lehmann R, Fichtlscherer S, Vasa M, Urbich C, Mildner-Rihm C, Martin H, Zeiher AM, Dimmeler S. Erythropoietin is a potent physiologic stimulus for endothelial progenitor cell mobilization. Blood. 2003;102:1340-1346

37. Bahlmann FH, De Groot K, Spandau JM, Landry AL, Hertel B, Duckert T, Boehm SM, Menne J, Haller H, Fliser D. Erythropoietin regulates endothelial progenitor cells. Blood. 2004;103:921-926

38. Hristov M, Erl W, Linder S, Weber PC. Apoptotic bodies from endothelial cells enhance the number and initiate the differentiation of human endothelial progenitor cells in vitro. Blood. 2004;104:2761-2766

39. Asahara T, Masuda H, Takahashi T, Kalka C, Pastore C, Silver M, Kearne M, Magner M, Isner JM. Bone marrow origin of endothelial progenitor cells responsible for postnatal vasculogenesis in physiological and pathological neovascularization. Circ Res. 1999;85:221-228

40. Jackson KA, Majka SM, Wang H, Pocius J, Hartley CJ, Majesky MW, Entman ML, Michael LH, Hirschi KK, Goodell MA. Regeneration of ischemic cardiac muscle and vascular endothelium by adult stem cells. J Clin Invest. 2001;107:1395-1402 
41. Shi Q, Rafii S, Wu MH, Wijelath ES, Yu C, Ishida A, Fujita Y, Kothari S, Mohle R, Sauvage LR, Moore MA, Storb RF, Hammond WP. Evidence for circulating bone marrow-derived endothelial cells. Blood. 1998;92:362-367

42. Gunsilius E, Duba HC, Petzer AL, Kahler CM, Gastl GA. Contribution of endothelial cells of hematopoietic origin to blood vessel formation. Circ Res. 2001;88:E1

43. Rafii S, Lyden D. Therapeutic stem and progenitor cell transplantation for organ vascularization and regeneration. Nat Med. 2003;9:702-712

44. Asahara T, Takahashi T, Masuda H, Kalka C, Chen D, Iwaguro H, Inai Y, Silver M, Isner JM. VEGF contributes to postnatal neovascularization by mobilizing bone marrow-derived endothelial progenitor cells. Embo J. 1999;18:3964-3972

45. Yamashita J, Itoh H, Hirashima M, Ogawa M, Nishikawa S, Yurugi T, Naito M, Nakao K. Flk1-positive cells derived from embryonic stem cells serve as vascular progenitors. Nature. 2000;408:92-96

46. Aicher A, Heeschen C, Mildner-Rihm C, Urbich C, Ihling C, Technau-Ihling K, Zeiher AM, Dimmeler S. Essential role of endothelial nitric oxide synthase for mobilization of stem and progenitor cells. Nat Med. 2003;9:1370-1376

47. Dimmeler S, Dernbach E, Zeiher AM. Phosphorylation of the endothelial nitric oxide synthase at ser1177 is required for VEGF-induced endothelial cell migration. FEBS Lett. 2000;477:258-262

48. Landmesser U, Engberding N, Bahlmann FH, Schaefer A, Wiencke A, Heineke A, Spiekermann S, Hilfiker-Kleiner D, Templin C, Kotlarz D, Mueller M, Fuchs M, Hornig B, Haller H, Drexler H. Statininduced improvement of endothelial progenitor cell mobilization, myocardial neovascularization, left ventricular function, and survival after experimental myocardial infarction requires endothelial nitric oxide synthase. Circulation. 2004;110:1933-1939

49. Morales-Ruiz M, Fulton D, Sowa G, Languino LR, Fujio Y, Walsh K, Sessa WC. Vascular endothelial growth factor-stimulated actin reorganization and migration of endothelial cells is regulated via the serine/threonine kinase Akt. Circ Res. 2000;86:892-896

50. Sandri M, Adams V, Gielen S, Linke A, Lenk K, Krankel N, Lenz D, Erbs S, Scheinert D, Mohr FW, Schuler G, Hambrecht R. Effects of exercise and ischemia on mobilization and functional activation of bloodderived progenitor cells in patients with ischemic syndromes: results of 3 randomized studies. Circulation. 2005;111:3391-3399

51. Gill M, Dias S, Hattori K, Rivera ML, Hicklin D, Witte L, Girardi L, Yurt R, Himel H, Rafii S. Vascular trauma induces rapid but transient mobilization of VEGFR2(+)AC133(+) endothelial precursor cells. Circ Res. 2001;88:167-174

52. Adams V, Lenk K, Linke A, Lenz D, Erbs S, Sandri M, Tarnok A, Gielen S, Emmrich F, Schuler G, Hambrecht R. Increase of circulating endothelial progenitor cells in patients with coronary artery disease after exercise-induced ischemia. Arterioscler Thromb Vasc Biol. 2004;24:684-690

53. Massa M, Rosti V, Ferrario M, Campanelli R, Ramajoli I, Rosso R, De Ferrari GM, Ferlini M, Goffredo L, Bertoletti A, Klersy C, Pecci A, Moratti R, Tavazzi L. Increased circulating hematopoietic and endothelial progenitor cells in the early phase of acute myocardial infarction. Blood. 2005;105:199-206

54. Shintani S, Murohara T, Ikeda H, Ueno T, Honma T, Katoh A, Sasaki K, Shimada T, Oike Y, Imaizumi T. Mobilization of endothelial progenitor cells in patients with acute myocardial infarction. Circulation. 2001;103:2776-2779

55. Kalka C, Masuda H, Takahashi T, Gordon R, Tepper O, Gravereaux E, Pieczek A, Iwaguro H, Hayashi SI, Isner JM, Asahara T. Vascular endothelial growth factor(165) gene transfer augments circulating endothelial progenitor cells in human subjects. Circ Res. 2000;86:1198-1202

56. Holmen C, Elsheikh E, Stenvinkel P, Qureshi AR, Pettersson E, Jalkanen S, Sumitran-Holgersson S. Circulating inflammatory endothelial cells contribute to endothelial progenitor cell dysfunction in patients with vasculitis and kidney involvement. J Am Soc Nephrol. 2005;16:3110-3120

57. Ross R. Atherosclerosis--an inflammatory disease. N Engl J Med. 1999;340:115-126

58. Strehlow K, Werner N, Berweiler J, Link A, Dirnagl U, Priller J, Laufs K, Ghaeni L, Milosevic M, Bohm M, Nickenig G. Estrogen increases bone marrow-derived endothelial progenitor cell production and diminishes neointima formation. Circulation. 2003;107:3059-3065

59. Vasa M, Fichtlscherer S, Adler K, Aicher A, Martin H, Zeiher AM, Dimmeler S. Increase in circulating endothelial progenitor cells by statin therapy in patients with stable coronary artery disease. Circulation. 2001;103:2885-2890 
60. Laufs U, Urhausen A, Werner N, Scharhag J, Heitz A, Kissner G, Bohm M, Kindermann W, Nickenig G. Running exercise of different duration and intensity: effect on endothelial progenitor cells in healthy subjects. Eur J Cardiovasc Prev Rehabil. 2005;12:407-414

61. Westerweel PE, Hoefer IE, Blankestijn PJ, de Bree P, Groeneveld D, van Oostrom O, Braam B, Koomans HA, Verhaar MC. End-stage renal disease causes an imbalance between endothelial and smooth muscle progenitor cells. Am J Physiol Renal Physiol. 2007;292:F1132-1140

62. Fadini GP, Sartore S, Albiero M, Baesso I, Murphy E, Menegolo M, Grego F, Vigili de Kreutzenberg S, Tiengo A, Agostini C, Avogaro A. Number and function of endothelial progenitor cells as a marker of severity for diabetic vasculopathy. Arterioscler Thromb Vasc Biol. 2006;26:2140-2146

63. Vasa M, Fichtlscherer S, Aicher A, Adler K, Urbich C, Martin H, Zeiher AM, Dimmeler S. Number and migratory activity of circulating endothelial progenitor cells inversely correlate with risk factors for coronary artery disease. Circ Res. 2001;89:E1-7

64. Chironi G, Walch L, Pernollet MG, Gariepy J, Levenson J, Rendu F, Simon A. Decreased number of circulating CD34+KDR+ cells in asymptomatic subjects with preclinical atherosclerosis. Atherosclerosis. 2007; $191: 115-120$

65. Fadini GP, Coracina A, Baesso I, Agostini C, Tiengo A, Avogaro A, de Kreutzenberg SV. Peripheral blood CD34+KDR+ endothelial progenitor cells are determinants of subclinical atherosclerosis in a middleaged general population. Stroke. 2006;37:2277-2282

66. Fadini GP, Sartore S, Baesso I, Lenzi M, Agostini C, Tiengo A, Avogaro A. Endothelial progenitor cells and the diabetic paradox. Diabetes Care. 2006;29:714-716

67. Fadini GP, Schiavon M, Cantini M, Baesso I, Facco M, Miorin M, Tassinato M, Kreutzenberg SV, Avogaro A, Agostini C. Circulating progenitor cells are reduced in patients with severe lung disease. Stem Cells. 2006;24:1806-1813

68. Rehman J, Li J, Parvathaneni L, Karlsson G, Panchal VR, Temm CJ, Mahenthiran J, March KL. Exercise acutely increases circulating endothelial progenitor cells and monocyte-/macrophage-derived angiogenic cells. J Am Coll Cardiol. 2004;43:2314-2318

69. Sugawara J, Mitsui-Saito M, Hoshiai T, Hayashi C, Kimura Y, Okamura K. Circulating endothelial progenitor cells during human pregnancy. J Clin Endocrinol Metab. 2005;90:1845-1848

70. Choi JH, Kim KL, Huh W, Kim B, Byun J, Suh W, Sung J, Jeon ES, Oh HY, Kim DK. Decreased number and impaired angiogenic function of endothelial progenitor cells in patients with chronic renal failure. Arterioscler Thromb Vasc Biol. 2004;24:1246-1252

71. Soler MJ, Martinez-Estrada OM, Puig-Mari JM, Marco-Feliu D, Oliveras A, Vila J, Mir M, Orfila A, Vilaro $\mathrm{S}$, Lloveras J. Circulating endothelial progenitor cells after kidney transplantation. Am J Transplant. 2005;5:2154-2159

72. Guven H, Shepherd RM, Bach RG, Capoccia BJ, Link DC. The number of endothelial progenitor cell colonies in the blood is increased in patients with angiographically significant coronary artery disease. J Am Coll Cardiol. 2006;48:1579-1587

73. Powell TM, Paul JD, Hill JM, Thompson M, Benjamin M, Rodrigo M, McCoy JP, Read EJ, Khuu HM, Leitman SF, Finkel T, Cannon RO, 3rd. Granulocyte colony-stimulating factor mobilizes functional endothelial progenitor cells in patients with coronary artery disease. Arterioscler Thromb Vasc Biol. 2005;25:296-301

74. Bahlmann FH, de Groot K, Mueller O, Hertel B, Haller H, Fliser D. Stimulation of endothelial progenitor cells: a new putative therapeutic effect of angiotensin II receptor antagonists. Hypertension. 2005;45:526-529

75. Banerjee S, Brilakis E, Zhang S, Roesle M, Lindsey J, Philips B, Blewett CG, Terada LS. Endothelial progenitor cell mobilization after percutaneous coronary intervention. Atherosclerosis. 2006

76. Croce G, Passacquale G, Necozione S, Ferri C, Desideri G. Nonpharmacological treatment of hypercholesterolemia increases circulating endothelial progenitor cell population in adults. Arterioscler Thromb Vasc Biol. 2006;26:e38-39

77. Min TQ, Zhu CJ, Xiang WX, Hui ZJ, Peng SY. Improvement in endothelial progenitor cells from peripheral blood by ramipril therapy in patients with stable coronary artery disease. Cardiovasc Drugs Ther. 2004;18:203-209

78. Hughes AD, Coady E, Raynor S, Mayet J, Wright AR, Shore AC, Kooner JS, Thom SA, Chaturvedi N. Reduced endothelial progenitor cells in European and South Asian men with atherosclerosis. Eur J Clin Invest. 2007;37:35-41 
79. Hristov M, Fach C, Becker C, Heussen N, Liehn EA, Blindt R, Hanrath P, Weber C. Reduced numbers of circulating endothelial progenitor cells in patients with coronary artery disease associated with longterm statin treatment. Atherosclerosis. 2007;192:413-420

80. Zhu J, Wang X, Chen J, Sun J, Zhang F. Reduced number and activity of circulating endothelial progenitor cells from patients with hyperhomocysteinemia. Arch Med Res. 2006;37:484-489

81. Chen JZ, Zhang FR, Tao QM, Wang XX, Zhu JH. Number and activity of endothelial progenitor cells from peripheral blood in patients with hypercholesterolaemia. Clin Sci (Lond). 2004;107:273-280

82. Grisar J, Aletaha D, Steiner CW, Kapral T, Steiner S, Seidinger D, Weigel G, Schwarzinger I, Wolozcszuk W, Steiner G, Smolen JS. Depletion of endothelial progenitor cells in the peripheral blood of patients with rheumatoid arthritis. Circulation. 2005;111:204-211

83. Herbrig K, Haensel S, Oelschlaegel U, Pistrosch F, Foerster S, Passauer J. Endothelial dysfunction in patients with rheumatoid arthritis is associated with a reduced number and impaired function of endothelial progenitor cells. Ann Rheum Dis. 2006;65:157-163

84. Lambiase PD, Edwards RJ, Anthopoulos P, Rahman S, Meng YG, Bucknall CA, Redwood SR, Pearson JD, Marber MS. Circulating humoral factors and endothelial progenitor cells in patients with differing coronary collateral support. Circulation. 2004;109:2986-2992

85. Loomans CJ, de Koning EJ, Staal FJ, Rookmaaker MB, Verseyden C, de Boer HC, Verhaar MC, Braam B, Rabelink TJ, van Zonneveld AJ. Endothelial progenitor cell dysfunction: a novel concept in the pathogenesis of vascular complications of type 1 diabetes. Diabetes. 2004;53:195-199

86. Pellegatta F, Bragheri M, Grigore L, Raselli S, Maggi FM, Brambilla C, Reduzzi A, Pirillo A, Norata GD, Catapano AL. In vitro isolation of circulating endothelial progenitor cells is related to the high density lipoprotein plasma levels. Int J Mol Med. 2006;17:203-208

87. Valgimigli M, Rigolin GM, Fucili A, Porta MD, Soukhomovskaia O, Malagutti P, Bugli AM, Bragotti LZ, Francolini G, Mauro E, Castoldi G, Ferrari R. CD34+ and endothelial progenitor cells in patients with various degrees of congestive heart failure. Circulation. 2004;110:1209-1212

88. Kunz GA, Liang G, Cuculoski F, Gregg D, Vata KC, Shaw LK, Goldschmidt-Clermont PJ, Dong C, Taylor DA, Peterson ED. Circulating endothelial progenitor cells predict coronary artery disease severity. Am Heart J. 2006;152:190-195

89. Lev El, Kleiman NS, Birnbaum Y, Harris D, Korbling M, Estrov Z. Circulating endothelial progenitor cells and coronary collaterals in patients with non-ST segment elevation myocardial infarction. $J$ Vasc Res. 2005;42:408-414

90. Fadini GP, Miorin M, Facco M, Bonamico S, Baesso I, Grego F, Menegolo M, de Kreutzenberg SV, Tiengo A, Agostini C, Avogaro A. Circulating endothelial progenitor cells are reduced in peripheral vascular complications of type 2 diabetes mellitus. J Am Coll Cardiol. 2005;45:1449-1457

91. Suh W, Kim KL, Choi JH, Lee YS, Lee JY, Kim JM, Jang HS, Shin IS, Lee JS, Byun J, Jeon ES, Kim DK. Creactive protein impairs angiogenic functions and decreases the secretion of arteriogenic chemocytokines in human endothelial progenitor cells. Biochem Biophys Res Commun. 2004;321:65-71

92. Tepper OM, Galiano RD, Capla JM, Kalka C, Gagne PJ, Jacobowitz GR, Levine JP, Gurtner GC. Human endothelial progenitor cells from type II diabetics exhibit impaired proliferation, adhesion, and incorporation into vascular structures. Circulation. 2002;106:2781-2786

93. Wang X, Chen J, Tao Q, Zhu J, Shang Y. Effects of ox-LDL on number and activity of circulating endothelial progenitor cells. Drug Chem Toxicol. 2004;27:243-255

94. Chen TG, Chen JZ, Xie XD. Effects of aspirin on number, activity and inducible nitric oxide synthase of endothelial progenitor cells from peripheral blood. Acta Pharmacol Sin. 2006;27:430-436

95. Landmesser U, Bahlmann F, Mueller M, Spiekermann S, Kirchhoff N, Schulz S, Manes C, Fischer D, de Groot K, Fliser D, Fauler G, Marz W, Drexler H. Simvastatin versus ezetimibe: pleiotropic and lipidlowering effects on endothelial function in humans. Circulation. 2005;111:2356-2363

96. Schömig K, Busch G, Steppich B, Sepp D, Kaufmann J, Stein A, Schömig A, Ott I. Interleukin-8 is associated with circulating $\mathrm{CD} 133+$ progenitor cells in acute myocardial infarction. Eur Heart $J$. 2006;27:1032-1037

97. Garolla A, D'Inca R, Checchin D, Biagioli A, De Toni L, Nicoletti V, Scarpa M, Bolzonello E, Sturniolo GC, Foresta $C$. Reduced endothelial progenitor cell number and function in inflammatory bowel disease: a possible link to the pathogenesis. Am J Gastroenterol. 2009;104:2500-2507 
98. Junhui Z, Xiaojing H, Binquan Z, Xudong X, Junzhu C, Guosheng F. Nicotine-reduced endothelial progenitor cell senescence through augmentation of telomerase activity via the PI3K/Akt pathway. Cytotherapy. 2009;11:485-491

99. Egan CG, Caporali F, Huqi AF, Zito MC, Focardi M, Mondillo S, Pierli C, Marzilli M, Sorrentino V. Reduced levels of putative endothelial progenitor and CXCR4+ cells in coronary artery disease: kinetics following percutaneous coronary intervention and association with clinical characteristics. Thromb Haemost. 2009;101:1138-1146

100. Rafat N, Beck G, Schulte J, Tuettenberg J, Vajkoczy P. Circulating endothelial progenitor cells in malignant gliomas. J Neurosurg. 2010;112:43-49

101. Desai A, Glaser A, Liu D, Raghavachari N, Blum A, Zalos G, Lippincott M, McCoy JP, Munson PJ, Solomon MA, Danner RL, Cannon RO, 3rd. Microarray-based characterization of a colony assay used to investigate endothelial progenitor cells and relevance to endothelial function in humans. Arterioscler Thromb Vasc Biol. 2009;29:121-127

102. MacEneaney OJ, Kushner EJ, Van Guilder GP, Greiner JJ, Stauffer BL, DeSouza CA. Endothelial progenitor cell number and colony-forming capacity in overweight and obese adults. Int J Obes (Lond). 2009;33:219-225

103. Chen MC, Chen CJ, Yang CH, Liu WH, Fang CY, Hsieh YK, Chang HW. Relationship of the percentage of circulating endothelial progenitor cell to the severity of coronary artery disease. Heart Vessels. 2008;23:47-52

104. Fadini GP, de Kreutzenberg S, Albiero M, Coracina A, Pagnin E, Baesso I, Cignarella A, Bolego C, Plebani M, Nardelli GB, Sartore S, Agostini C, Avogaro A. Gender differences in endothelial progenitor cells and cardiovascular risk profile: the role of female estrogens. Arterioscler Thromb Vasc Biol. 2008;28: 997-1004

105. Junhui Z, Xingxiang W, Guosheng F, Yunpeng S, Furong Z, Junzhu C. Reduced number and activity of circulating endothelial progenitor cells in patients with idiopathic pulmonary arterial hypertension. Respir Med. 2008;102:1073-1079

106. Fadini GP, Pucci L, Vanacore R, Baesso I, Penno G, Balbarini A, Di Stefano R, Miccoli R, de Kreutzenberg S, Coracina A, Tiengo A, Agostini C, Del Prato S, Avogaro A. Glucose tolerance is negatively associated with circulating progenitor cell levels. Diabetologia. 2007;50:2156-2163

107. Passacquale G, Desideri G, Croce G, Murgo S, Mancarelli MM, Zazzeroni F, Alesse E, Ferri C. Nifedipine improves the migratory ability of circulating endothelial progenitor cells depending on manganese superoxide dismutase upregulation. $J$ Hypertens. 2008;26:737-746

108. Jung KH, Chu K, Lee ST, Park HK, Kim DH, Kim JH, Bahn JJ, Song EC, Kim M, Lee SK, Roh JK. Circulating endothelial progenitor cells as a pathogenetic marker of moyamoya disease. J Cereb Blood Flow Metab. 2008;28:1795-1803

109. Chen J, Wang X, Zhu J, Shang Y, Guo X, Sun J. Effects of Ginkgo biloba extract on number and activity of endothelial progenitor cells from peripheral blood. J Cardiovasc Pharmacol. 2004;43:347-352

110. DiFabio JM, Thomas GR, Zucco L, Kuliszewski MA, Bennett BM, Kutryk MJ, Parker JD. Nitroglycerin attenuates human endothelial progenitor cell differentiation, function, and survival. J Pharmacol Exp Ther. 2006;318:117-123

111. Wang HY, Gao PJ, Ji KD, Shen WF, Fan CL, Lu L, Zhu DL. Circulating endothelial progenitor cells, Creactive protein and severity of coronary stenosis in Chinese patients with coronary artery disease. Hypertens Res. 2007;30:133-141

112. Hwang HS, Maeng YS, Park YW, Koos BJ, Kwon YG, Kim YH. Increased senescence and reduced functional ability of fetal endothelial progenitor cells in pregnancies complicated by preeclampsia without intrauterine growth restriction. Am J Obstet Gynecol. 2008;199:259 e251-257

113. Garg R, Tellez A, Alviar C, Granada J, Kleiman NS, Lev El. The effect of percutaneous coronary intervention on inflammatory response and endothelial progenitor cell recruitment. Catheter Cardiovasc Interv. 2008;72:205-209

114. Stein A, Montens HP, Steppich B, Busch G, Brandl R, Ott I. Circulating endothelial progenitor cells decrease in patients after endarterectomy. J Vasc Surg. 2008;48:1217-1222

115. Zhu J, Wang X, Shang Y, Xie X, Zhang F, Chen J, Fu G. Puerarin reduces endothelial progenitor cells senescence through augmentation of telomerase activity. Vascul Pharmacol. 2008;49:106-110 
116. Diller GP, van Eijl S, Okonko DO, Howard LS, Ali O, Thum T, Wort SJ, Bedard E, Gibbs JS, Bauersachs J, Hobbs AJ, Wilkins MR, Gatzoulis MA, Wharton J. Circulating endothelial progenitor cells in patients with Eisenmenger syndrome and idiopathic pulmonary arterial hypertension. Circulation. 2008;117:3020-3030

117. Briguori C, Testa U, Riccioni R, Colombo A, Petrucci E, Condorelli G, Mariani G, D'Andrea D, De Micco F, Rivera NV, Puca AA, Peschle C. Correlations between progression of coronary artery disease and circulating endothelial progenitor cells. Faseb J. 2010;24:1981-1988

118. Spyridopoulos I, Haendeler J, Urbich C, Brummendorf TH, Oh H, Schneider MD, Zeiher AM, Dimmeler S. Statins enhance migratory capacity by upregulation of the telomere repeat-binding factor TRF2 in endothelial progenitor cells. Circulation. 2004;110:3136-3142

119. Pescini F, Cesari F, Giusti B, Sarti C, Zicari E, Bianchi S, Dotti MT, Federico A, Balestrino M, Enrico A, Gandolfo C, Gori AM, Abbate R, Pantoni L, Inzitari D. Bone marrow-derived progenitor cells in cerebral autosomal dominant arteriopathy with subcortical infarcts and leukoencephalopathy. Stroke. 2010;41:218-223

120. Huang PH, Chen YH, Tsai HY, Chen JS, Wu TC, Lin FY, Sata M, Chen JW, Lin SJ. Intake of red wine increases the number and functional capacity of circulating endothelial progenitor cells by enhancing nitric oxide bioavailability. Arterioscler Thromb Vasc Biol. 2010;30:869-877

121. Pelliccia F, Pasceri V, Cianfrocca C, Vitale C, Speciale G, Gaudio C, Rosano GM, Mercuro G. Angiotensin II receptor antagonism with telmisartan increases number of endothelial progenitor cells in normotensive patients with coronary artery disease: a randomized, double-blind, placebo-controlled study. Atherosclerosis. 2010;210:510-515

122. Hamed S, Brenner B, Abassi Z, Aharon A, Daoud D, Roguin A. Hyperglycemia and Oxidized-LDL exert a deleterious effect on Endothelial Progenitor Cell migration in Type 2 Diabetes Mellitus. Thromb Res. 2010;126:166-174

123. Luppi P, Powers RW, Verma V, Edmunds L, Plymire D, Hubel CA. Maternal circulating CD34+VEGFR-2+ and CD133+VEGFR-2 + progenitor cells increase during normal pregnancy but are reduced in women with preeclampsia. Reprod Sci. 2010;17:643-652

124. Ablin JN, Boguslavski V, Aloush V, Elkayam O, Paran D, Levartovski D, Caspi D, George J. Enhanced adhesive properties of endothelial progenitor cells (EPCS) in patients with SLE. Rheumatol Int. 2011; 31:773-778

125. Fadini GP, Albiero M, Boscaro E, Menegazzo L, Cabrelle A, Piliego T, Federici M, Agostini C, Avogaro A. Rosuvastatin stimulates clonogenic potential and anti-inflammatory properties of endothelial progenitor cells. Cell Biol Int. 2010;34:709-715

126. Benndorf RA, Gehling UM, Appel D, Maas R, Schwedhelm E, Schlagner K, Silberhorn E, Hossfeld DK, Rogiers $\mathrm{X}$, Boger R. Mobilization of putative high-proliferative-potential endothelial colony-forming cells during antihypertensive treatment in patients with essential hypertension. Stem Cells Dev. 2007;16:329-338

127. Delva P, De Marchi S, Prior M, Degan M, Lechi A, Trettene M, Arosio E. Endothelial progenitor cells in patients with severe peripheral arterial disease. Endothelium. 2008;15:246-253

128. Thijssen DH, Vos JB, Verseyden C, van Zonneveld AJ, Smits P, Sweep FC, Hopman MT, de Boer HC. Haematopoietic stem cells and endothelial progenitor cells in healthy men: effect of aging and training. Aging Cell. 2006;5:495-503

129. Keymel S, Kalka C, Rassaf T, Yeghiazarians Y, Kelm M, Heiss C. Impaired endothelial progenitor cell function predicts age-dependent carotid intimal thickening. Basic Res Cardiol. 2008;103:582-586

130. Xiao Q, Kiechl S, Patel S, Oberhollenzer F, Weger S, Mayr A, Metzler B, Reindl M, Hu Y, Willeit J, Xu Q. Endothelial progenitor cells, cardiovascular risk factors, cytokine levels and atherosclerosis - results from a large population-based study. PLoS ONE. 2007;2:e975

131. Schatteman GC, Hanlon HD, Jiao C, Dodds SG, Christy BA. Blood-derived angioblasts accelerate bloodflow restoration in diabetic mice. J Clin Invest. 2000;106:571-578

132. Yoon YS, Lee N, Scadova H. Myocardial regeneration with bone-marrow-derived stem cells. Biol Cell. 2005;97:253-263

133. Badorff C, Brandes RP, Popp R, Rupp S, Urbich C, Aicher A, Fleming I, Busse R, Zeiher AM, Dimmeler S. Transdifferentiation of blood-derived human adult endothelial progenitor cells into functionally active cardiomyocytes. Circulation. 2003;107:1024-1032

134. Carmeliet P. Angiogenesis in health and disease. Nat Med. 2003;9:653-660 
135. Risau W. Mechanisms of angiogenesis. Nature. 1997;386:671-674

136. Assmus B, Schachinger V, Teupe C, Britten M, Lehmann R, Dobert N, Grunwald F, Aicher A, Urbich C, Martin H, Hoelzer D, Dimmeler S, Zeiher AM. Transplantation of Progenitor Cells and Regeneration Enhancement in Acute Myocardial Infarction (TOPCARE-AMI). Circulation. 2002;106:3009-3017

137. Assmus B, Honold J, Schachinger V, Britten MB, Fischer-Rasokat U, Lehmann R, Teupe C, Pistorius K, Martin H, Abolmaali ND, Tonn T, Dimmeler S, Zeiher AM. Transcoronary transplantation of progenitor cells after myocardial infarction. N Engl J Med. 2006;355:1222-1232

138. Numaguchi Y, Sone T, Okumura K, Ishii M, Morita Y, Kubota R, Yokouchi K, Imai H, Harada M, Osanai H, Kondo T, Murohara T. The impact of the capability of circulating progenitor cell to differentiate on myocardial salvage in patients with primary acute myocardial infarction. Circulation. 2006;114: 1114-119

139. Dobert N, Britten M, Assmus B, Berner U, Menzel C, Lehmann R, Hamscho N, Schachinger V, Dimmeler $S$, Zeiher AM, Grunwald F. Transplantation of progenitor cells after reperfused acute myocardial infarction: evaluation of perfusion and myocardial viability with FDG-PET and thallium SPECT. Eur $J$ Nucl Med Mol Imaging. 2004;31:1146-1151

140. Hristov M, Heussen N, Schober A, Weber C. Intracoronary infusion of autologous bone marrow cells and left ventricular function after acute myocardial infarction: a meta-analysis. $J \mathrm{Cell} \mathrm{Mol} \mathrm{Med}$. 2006;10:727-733

141. Dimmeler S, Zeiher AM, Schneider MD. Unchain my heart: the scientific foundations of cardiac repair. J Clin Invest. 2005;115:572-583

142. Higashi Y, Kimura M, Hara K, Noma K, Jitsuiki D, Nakagawa K, Oshima T, Chayama K, Sueda T, Goto C, Matsubara H, Murohara T, Yoshizumi M. Autologous bone-marrow mononuclear cell implantation improves endothelium-dependent vasodilation in patients with limb ischemia. Circulation. 2004;109:1215-1218

143. Tateishi-Yuyama E, Matsubara H, Murohara T, Ikeda U, Shintani S, Masaki H, Amano K, Kishimoto Y, Yoshimoto K, Akashi H, Shimada K, Iwasaka T, Imaizumi T. Therapeutic angiogenesis for patients with limb ischaemia by autologous transplantation of bone-marrow cells: a pilot study and a randomised controlled trial. Lancet. 2002;360:427-435

144. Au P, Daheron LM, Duda DG, Cohen KS, Tyrrell JA, Lanning RM, Fukumura D, Scadden DT, Jain RK. Differential in vivo potential of endothelial progenitor cells from human umbilical cord blood and adult peripheral blood to form functional long-lasting vessels. Blood. 2008;111:1302-1305

145. Taguchi A, Matsuyama T, Moriwaki H, Hayashi T, Hayashida K, Nagatsuka K, Todo K, Mori K, Stern DM, Soma T, Naritomi H. Circulating CD34-positive cells provide an index of cerebrovascular function. Circulation. 2004;109:2972-2975

146. Machalinski B, Paczkowska E, Koziarska D, Ratajczak MZ. Mobilization of human hematopoietic stem/progenitor-enriched CD34+ cells into peripheral blood during stress related to ischemic stroke. Folia Histochem Cytobiol. 2006;44:97-101

147. Yip HK, Chang LT, Chang WN, Lu CH, Liou CW, Lan MY, Liu JS, Youssef AA, Chang HW. Level and value of circulating endothelial progenitor cells in patients after acute ischemic stroke. Stroke. 2008;39:69-74

148. Cesari F, Nencini P, Nesi M, Caporale R, Giusti B, Abbate R, Gori AM, Inzitari D. Bone marrow-derived progenitor cells in the early phase of ischemic stroke: relation with stroke severity and discharge outcome. J Cereb Blood Flow Metab. 2009;29:1983-1990

149. Bogoslovsky T, Chaudhry A, Latour L, Maric D, Luby M, Spatz M, Frank J, Warach S. Endothelial progenitor cells correlate with lesion volume and growth in acute stroke. Neurology. 2010;75: 2059-2062

150. Ghani U, Shuaib A, Salam A, Nasir A, Shuaib U, Jeerakathil T, Sher F, O'Rourke F, Nasser AM, Schwindt B, Todd K. Endothelial progenitor cells during cerebrovascular disease. Stroke. 2005;36:151-153

151. Chu K, Jung KH, Lee ST, Park HK, Sinn DI, Kim JM, Kim DH, Kim JH, Kim SJ, Song EC, Kim M, Lee SK, Roh JK. Circulating endothelial progenitor cells as a new marker of endothelial dysfunction or repair in acute stroke. Stroke. 2008;39:1441-1447

152. Ciulla MM, Giorgetti A, Giordano R, Silvestris I, Cortiana M, Paliotti R, Lazzari L. Circulating endothelial progenitor cell colony-forming capacity in healthy subjects: how does an endothelial colony look like? Am J Cardiol. 2007;100:559-560

153. Bliss T, Guzman R, Daadi M, Steinberg GK. Cell transplantation therapy for stroke. Stroke. 2007;38: 817-826 
154. Gertz K, Priller J, Kronenberg G, Fink KB, Winter B, Schrock H, Ji S, Milosevic M, Harms C, Bohm M, Dirnagl U, Laufs $U$, Endres $M$. Physical activity improves long-term stroke outcome via endothelial nitric oxide synthase-dependent augmentation of neovascularization and cerebral blood flow. Circ Res. 2006;99:1132-1140

155. Sobrino T, Hurtado O, Moro MA, Rodriguez-Yanez M, Castellanos M, Brea D, Moldes O, Blanco M, Arenillas JF, Leira R, Davalos A, Lizasoain I, Castillo J. The increase of circulating endothelial progenitor cells after acute ischemic stroke is associated with good outcome. Stroke. 2007;38:2759-2764

156. Lee SC, Lee KY, Kim YJ, Kim SH, Koh SH, Lee YJ. Serum VEGF levels in acute ischaemic strokes are correlated with long-term prognosis. Eur J Neurol. 2010;17:45-51

157. Hess DC, Hill WD, Martin-Studdard A, Carroll J, Brailer J, Carothers J. Bone marrow as a source of endothelial cells and NeuN-expressing cells After stroke. Stroke. 2002;33:1362-1368

158. Zhang ZG, Zhang L, Jiang Q, Chopp M. Bone marrow-derived endothelial progenitor cells participate in cerebral neovascularization after focal cerebral ischemia in the adult mouse. Circ Res. 2002;90:284-288

159. Galimi F, Summers RG, van Praag H, Verma IM, Gage FH. A role for bone marrow-derived cells in the vasculature of noninjured CNS. Blood. 2005;105:2400-2402

160. Slevin M, Kumar P, Gaffney J, Kumar S, Krupinski J. Can angiogenesis be exploited to improve stroke outcome? Mechanisms and therapeutic potential. Clin Sci (Lond). 2006;111:171-183

161. Fan Y, Yang GY. Therapeutic angiogenesis for brain ischemia: a brief review. J Neuroimmune Pharmacol. 2007;2:284-289

162. Kokaia Z, Lindvall O. Neurogenesis after ischaemic brain insults. Curr Opin Neurobiol. 2003;13:127-132

163. Thored P, Wood J, Arvidsson A, Cammenga J, Kokaia Z, Lindvall O. Long-term neuroblast migration along blood vessels in an area with transient angiogenesis and increased vascularization after stroke. Stroke. 2007;38:3032-3039

164. Gama Sosa MA, De Gasperi R, Rocher AB, Perez GM, Simons K, Cruz DE, Hof PR, Elder GA. Interactions of primary neuroepithelial progenitor and brain endothelial cells: distinct effect on neural progenitor maintenance and differentiation by soluble factors and direct contact. Cell Res. 2007;17:619-626

165. Schänzer A, Wachs FP, Wilhelm D, Acker T, Cooper-Kuhn C, Beck H, Winkler J, Aigner L, Plate KH, Kuhn HG. Direct stimulation of adult neural stem cells in vitro and neurogenesis in vivo by vascular endothelial growth factor. Brain Pathol. 2004;14:237-248

166. Chen J, Zhang ZG, Li Y, Wang L, Xu YX, Gautam SC, Lu M, Zhu Z, Chopp M. Intravenous administration of human bone marrow stromal cells induces angiogenesis in the ischemic boundary zone after stroke in rats. Circ Res. 2003;92:692-699

167. Taguchi A, Soma T, Tanaka H, Kanda T, Nishimura H, Yoshikawa H, Tsukamoto Y, Iso H, Fujimori Y, Stern DM, Naritomi H, Matsuyama T. Administration of CD34+ cells after stroke enhances neurogenesis via angiogenesis in a mouse model. J Clin Invest. 2004;114:330-338

168. Chen J, Zacharek A, Zhang C, Jiang H, Li Y, Roberts C, Lu M, Kapke A, Chopp M. Endothelial nitric oxide synthase regulates brain-derived neurotrophic factor expression and neurogenesis after stroke in mice. J Neurosci. 2005;25:2366-2375

169. Noguchi CT, Asavaritikrai P, Teng R, Jia Y. Role of erythropoietin in the brain. Crit Rev Oncol Hematol. 2007;64:159-171

170. Wang L, Zhang Z, Wang Y, Zhang R, Chopp M. Treatment of stroke with erythropoietin enhances neurogenesis and angiogenesis and improves neurological function in rats. Stroke. 2004;35:1732-1737

171. Zhang RL, Zhang ZG, Chopp M. Neurogenesis in the adult ischemic brain: generation, migration, survival, and restorative therapy. Neuroscientist. 2005;11:408-416

172. Zhao LR, Duan WM, Reyes M, Keene CD, Verfaillie CM, Low WC. Human bone marrow stem cells exhibit neural phenotypes and ameliorate neurological deficits after grafting into the ischemic brain of rats. Exp Neurol. 2002;174:11-20

173. Kinnaird T, Stabile E, Burnett MS, Epstein SE. Bone-marrow-derived cells for enhancing collateral development: mechanisms, animal data, and initial clinical experiences. Circ Res. 2004;95:354-363

174. Chen J, Sanberg PR, Li Y, Wang L, Lu M, Willing AE, Sanchez-Ramos J, Chopp M. Intravenous administration of human umbilical cord blood reduces behavioral deficits after stroke in rats. Stroke. 2001;32:2682-2688

175. Vendrame M, Cassady J, Newcomb J, Butler T, Pennypacker KR, Zigova T, Sanberg CD, Sanberg PR, Willing AE. Infusion of human umbilical cord blood cells in a rat model of stroke dose-dependently rescues behavioral deficits and reduces infarct volume. Stroke. 2004;35:2390-2395 
176. Borlongan CV, Evans A, Yu G, Hess DC. Limitations of intravenous human bone marrow CD133+ cell grafts in stroke rats. Brain Res. 2005;1048:116-122

177. Li Y, Chen J, Chen XG, Wang L, Gautam SC, Xu YX, Katakowski M, Zhang LJ, Lu M, Janakiraman N, Chopp $M$. Human marrow stromal cell therapy for stroke in rat: neurotrophins and functional recovery. Neurology. 2002;59:514-523

178. Kang SK, Lee DH, Bae YC, Kim HK, Baik SY, Jung JS. Improvement of neurological deficits by intracerebral transplantation of human adipose tissue-derived stromal cells after cerebral ischemia in rats. Exp Neurol. 2003;183:355-366

179. Fernando MS, Simpson JE, Matthews F, Brayne C, Lewis CE, Barber R, Kalaria RN, Forster G, Esteves F, Wharton SB, Shaw PJ, O'Brien JT, Ince PG. White matter lesions in an unselected cohort of the elderly: molecular pathology suggests origin from chronic hypoperfusion injury. Stroke. 2006;37:1391-1398

180. Wardlaw JM, Sandercock PA, Dennis MS, Starr J. Is breakdown of the blood-brain barrier responsible for lacunar stroke, leukoaraiosis, and dementia? Stroke. 2003;34:806-812

181. Caballero S, Sengupta N, Afzal A, Chang KH, Li Calzi S, Guberski DL, Kern TS, Grant MB. Ischemic vascular damage can be repaired by healthy, but not diabetic, endothelial progenitor cells. Diabetes. 2007; $56: 960-967$

182. Dufouil C, Chalmers J, Coskun O, Besancon V, Bousser MG, Guillon P, MacMahon S, Mazoyer B, Neal B, Woodward M, Tzourio-Mazoyer N, Tzourio C. Effects of blood pressure lowering on cerebral white matter hyperintensities in patients with stroke: the PROGRESS (Perindopril Protection Against Recurrent Stroke Study) Magnetic Resonance Imaging Substudy. Circulation. 2005;112:1644-1650 


\section{Chapter 6}

Haptoglobin phenotype may alter endothelial progenitor cell cluster formation in cerebral small vessel disease

Rouhl RPW

van Oostenbrugge RJ

Damoiseaux JGMC

Debrus-Palmans LL

Theunissen ROMFIH

Knottnerus ILH

Staals JEA

Delanghe JR

Cohen Tervaert JW

Lodder J

Current Neurovascular Research 2009;6:29-41 


\section{Abstract}

Cerebral small vessel disease results in silent ischemic lesions (SIL) among which is leukoaraiosis. In this process, endothelial damage is probably involved. Endothelial progenitor cells (EPC), are involved in endothelial repair. By restoring the damaged endothelium, EPC could mitigate SIL and cerebral small vessel disease. Haptoglobin 1-1, one of three phenotypes of haptoglobin, relates to SIL and may therefore attenuate the endothelial repair by EPC. Our aim was to quantify EPC number and function and to assess haptoglobin phenotype and its effect on EPC function in patients with a high prevalence of SIL: lacunar stroke patients. We assessed EPC in 42 lacunar stroke patients and 18 controls by flow cytometry and culture with fetal calf serum, patient and control serum. We determined haptoglobin phenotype and cultured EPC with the three different haptoglobin phenotypes. We found that EPC cluster counts were lower in patients (96.9 clusters/well \pm 83.4 (mean $\pm S D)$ ), especially in those with SIL $(85.0 \pm 64.3)$, than in controls $(174.4 \pm 112.2)$. Cluster formation was inhibited by patient serum, especially by SIL patient serum, but not by control serum. Patients with haptoglobin 1-1 had less clusters in culture, and when haptoglobin 1-1 was added to EPC cultures, cluster numbers were lower than with the other haptoglobin phenotypes. We conclude that lacunar stroke patients, especially those with SIL, have impaired EPC cluster formation, which may point at decreased endothelial repair potential. The haptoglobin 1-1 phenotype is likely a causative factor in this impairment. 


\section{Introduction}

Cerebral white matter lesions (leukoaraiosis) and asymptomatic lacunar infarcts, collectively termed silent ischemic lesions (SIL), are caused by cerebral small vessel disease, which also underlies lacunar stroke. SIL are associated with cognitive decline, increased risk of (recurrent) stroke, and a poorer prognosis. ${ }^{1,2}$ Endothelial dysfunction and damage is probably involved in the development and progression of cerebral small vessel disease. ${ }^{3}$ It might lead to an increased permeability of the blood-brain barrier and leakage of plasma proteins, with lacunar infarcts and white matter lesions as a consequence. ${ }^{4}$

Bone marrow derived endothelial progenitor cells (EPC) are involved in endothelial repair. Their numbers are lower and their cluster forming potential is decreased in patients with increased cardiovascular risk or stroke. ${ }^{5-7}$ Furthermore, lower EPC numbers as well as lower cluster forming potential, as measured shortly after stroke, relate to a poor prognosis regarding functional recovery. ${ }^{8,9}$ Regulating factors of EPC number or cluster forming potential in cerebrovascular disease remain elusive. ${ }^{10}$ In cerebral small vessel disease, however, EPC could attenuate the development of SIL by their endothelial restorative capacity.

Haptoglobin (Hpt) is an acute phase protein and has three different phenotypes. Earlier, we demonstrated that the Hpt phenotype 2-2 is underrepresented in lacunar stroke patients with SIL. ${ }^{11} \mathrm{Hpt}$ 2-2 relates to angiogenic potential, however, the mechanism for such effect is unclear. ${ }^{12}$ As EPC activity could mitigate the process of endothelial repair in SIL patients, potential differences in EPC response could be related to the Hpt phenotype.

We hypothesized that both EPC numbers and cluster forming potential are lower in patients with SIL than in controls. We also hypothesized that this difference might be due to the effects of different Hpt phenotypes. Therefore, we enumerated EPC, measured EPC cluster formation, determined Hpt phenotypes, and explored effects of patient serum and Hpt on EPC cluster formation in a patient population with a high prevalence of SIL: patients with a first-ever lacunar stroke.

\section{Materials and methods}

\section{Patients}

We included 42 lacunar stroke patients (event between May 2003 and December 2004) registered in the prospective Maastricht Stroke Registry (a database including all stroke patients over the age of 18 with symptoms lasting longer than 24 hours). ${ }^{2}$ Lacunar stroke was defined as an acute stroke syndrome with a lesion on imaging compatible with the occlusion of a single perforating small artery, consisting of a subcortical, demarcated lesion with a diameter $<15 \mathrm{~mm}$ on MRI. ${ }^{2}$ Furthermore, these patients had no evidence of a cardiac embolic source, nor signs of cerebral large vessel 
disease, or carotid stenosis on Duplex imaging (see de Jong et al. ${ }^{2}$ for criteria). 18 patients who visited the neurological outpatient department because of myogenic back pain, carpal tunnel syndrome, or other entrapment neuropathies, served as controls. They were free of any vascular or inflammatory disease, or hypertension, and were without silent ischemic lesions on cerebral MRI (see below). Vascular risk factor profiles were recorded as previously described. ${ }^{2}$ Characteristics of the study population are outlined in Table 6.1.

Table 6.1 Characteristics of patients and controls (at the time of blood sampling). Statistically significant differences indicated with *

\begin{tabular}{|c|c|c|c|}
\hline & Patients $(n=42)$ & Controls $(n=18)$ & $p$-value \\
\hline Age (mean ( \pm standard deviation (SD))) & $64.0( \pm 11.4)$ & $60.8( \pm 9.3)$ & 0.188 \\
\hline Male sex (n (\%)) & $22(66.7)$ & $8(44.4)$ & 0.152 \\
\hline Coronary artery disease $(\mathrm{n}(\%))$ & $8(19.0)$ & $0(0.0)$ & 0.091 \\
\hline Peripheral Vascular Disease (n (\%)) & $4(9.5)$ & $0(0.0)$ & 0.306 \\
\hline Diabetes (n (\%)) & $6(14.3)$ & $0(0.0)$ & 0.165 \\
\hline Current Smoking ( $(\%))$ & $20(47.6)$ & $6(33.3)$ & 0.262 \\
\hline Positive Family History (n (\%)) & $23(54.8)$ & $8(44.4)$ & 0.349 \\
\hline Statin Use (n (\%)) & 39 (92.9) & $0(0.0)$ & $<0.001^{*}$ \\
\hline ACE inhibitor Use (n (\%)) & $10(23.8)$ & $0(0.0)$ & 0.181 \\
\hline Angiotensin Receptor Blocker Use (n (\%)) & $18(42.9)$ & $0(0.0)$ & 0.060 \\
\hline Systolic Blood Pressure (mmHg; (mean ( \pm SD))) & $151.6( \pm 25.1)$ & $138.3( \pm 15.2)$ & $0.048 *$ \\
\hline Diastolic Blood Pressure (mmHg; (mean ( $\pm \mathrm{SD}))$ ) & $87.3( \pm 12.9)$ & $84.4( \pm 9.5)$ & 0.289 \\
\hline CRP $($ mean $( \pm S D))$ & $6.18( \pm 11.4)$ & $2.99( \pm 2.6)$ & 0.362 \\
\hline Glucose (mean $( \pm S D))$ & $6.2( \pm 2.5)$ & $5.3( \pm 0.5)$ & $0.016^{*}$ \\
\hline Cholesterol (Total) (mean ( \pm SD)) & $4.2( \pm 0.9)$ & $5.8( \pm 0.8)$ & $<0.001^{*}$ \\
\hline LDL Cholesterol (mean ( \pm SD)) & $2.5( \pm 0.9)$ & $4.0( \pm 0.8)$ & $<0.001^{*}$ \\
\hline HDL Cholesterol (mean ( $\pm S D))$ & $1.1( \pm 0.3)$ & $1.2( \pm 0.3)$ & 0.068 \\
\hline Triglycerides (mean $( \pm \mathrm{SD})$ ) & $1.54( \pm 1.4)$ & $1.07( \pm 0.6)$ & 0.112 \\
\hline
\end{tabular}

\section{Procedures}

To obtain results which were not confounded by acute phase responses, all lacunar stroke patients underwent the below mentioned procedures more than 2 years after the stroke, when they were in a stable clinical condition.

\section{MRI of the brain}

Both standard T2-weighted and fluid-attenuated inversion-recovery (FLAIR) sequences were used (Gyroscan ACS-NT; Powertrak 6000 Philips, Eindhoven, The Netherlands; scan parameters: 1.5 Tesla, field of view $23 * 23 \mathrm{~cm}$, matrix $512 * 512$; standard axial T2 (TR shortest, TE $100 \mathrm{~ms}$ ) and axial FLAIR (TR $8000 \mathrm{~ms}$, TE $120 \mathrm{~ms}$ ) images, all with slice thickness $5 \mathrm{~mm}$ and gaps of $0.50 \mathrm{~mm}$ ). Images were assessed by consensus by two 
vascular neurologists as described earlier. ${ }^{13}$ In short, the symptomatic lacunar infarct was defined as a hyperintense lesion on T2 images with corresponding hypointense lesions with a hyperintense rim on FLAIR, with a diameter of $<20 \mathrm{~mm}$, and its site corresponding to the clinical syndrome 2 years earlier. If no such lesion was visible, we used established criteria for lacunar stroke syndromes ${ }^{2}$ and certified that no other brain pathology as visible on MR imaging could account for the symptoms. Asymptomatic lacunar infarcts were defined as focal ischemic lesions in the lenticulostriatal and anterior choriodeal artery territories (deep cerebral regions) with similar radiologic properties. To estimate the extent of the periventricular and deep white matter lesions (WML), the Fazekas-scale was used. ${ }^{14}$ Extensive WML were defined as a score of 3 (periventricular hyperintensities with involvement of white matter) on the periventricular scale, and/or a score of 2 or 3 on the white matter scale (beginning confluence of lesions or large confluent lesions). Silent ischemic lesions (SIL) were defined as the presence of one or more asymptomatic infarcts and/or extensive WML.

\section{Blood}

For EPC quantification, $30 \mathrm{~mL}$ blood was sampled after an overnight fast, without the use of a tourniquet, and anticoagulated in heparin (standard $10 \mathrm{~mL}$ tubes, BD Biosciences, Breda, The Netherlands). Serum samples were collected in $5 \mathrm{~mL}$ tubes (BD Biosciences). At the same time, systolic and diastolic blood pressure (standard manometric measurement) were measured. Also, leukocyte count, blood glucose, hsCRP, total cholesterol, High Density Lipoprotein (HDL), and Low Density Lipoprotein (LDL) values (all with standardized patient care protocols) were obtained at this time point.

\section{Flow cytometry: counting EPC numbers}

A standard protocol adjusted for the probably low event rate of EPC was used. ${ }^{15}$ In short, we incubated 100 microliters of whole blood with the following monoclonal labelled antibodies: PerCP-anti-CD34 (BD Biosciences) PE-anti-KDR (R\&D Systems Europe, Abingdon, United Kingdom), and APC-anti-CD133 (Miltenyi Biotech, Utrecht, The Netherlands), for 30 minutes at $4^{\circ} \mathrm{C}$ in the dark. We used IgG1-PE, PerCP, and APC labelled antibodies (BD Biosciences) as isotype controls. After lysis of erythrocytes with ammoniumchloride, we counted cells with a FACSCalibur (BD Biosciences). Cells were gated in two steps, using CellQuest Software (BD Biosciences): 1) selection of CD34positive cells with side scatter similar to that of lymphocytes and monocytes, and 2) gating for KDR positive cells in this group. Double positive cells in isotype staining (same gating stategy) were subtracted from the total number of cells in the specific staining. Data were expressed as absolute number CD34+/KDR+-cells*10 $/ \mathrm{mL}$ full blood, as calculated from the total leukocyte count. 


\section{Cell culture: measuring EPC cluster formation}

For cell culture, we used two different methods simultaneously. ${ }^{5,6,10}$ In short, peripheral blood mononuclear cells were isolated by density gradient centrifugation (Lymphoprep, Axis, Oslo, Norway) and plated onto gelatin coated wells at $4 * 10^{6}$ cells per well (24 well plates) in $1 \mathrm{~mL}$ of medium (RPMI 1640 Glutamax I; Gibco/Invitrogen, Breda, The Netherlands) containing $20 \%$ heat-inactivated fetal calf serum (Integro BV, Lelystad, The Netherlands), $100 \mathrm{IU} / \mathrm{mL}$ penicillin and $100 \mathrm{microgram} / \mathrm{mL}$ streptomycin (Gibco), heparin (20 IE/mL; Leo Pharma, Breda, The Netherlands) and endothelial growth factors (extracted from bovine hypothalamus). Cells were cultured at $37^{\circ} \mathrm{C}$ and $5 \% \mathrm{CO}_{2}$. After 48 hours non-adherent cells were detached and replated on gelatin coated wells (at $1 * 10^{6}$ cells/well). Adherent cells were supplied with fresh medium. Cultures were continued until day 7 for both the initially non-adherent cells (termed Endothelial Cell Colony-Forming Units (CFU-EC); these cells probably paracrinely stimulate the recovery of damaged endothelium) ${ }^{16}$ and the adherent cells (termed Endothelial Colony Forming Cells (ECFC); these cells probably differentiate into mature endothelial cells). ${ }^{16}$ All cultures were performed in duplex. Clusters consisting of round cells, with emanating spindle shaped cells peripherally (see Figure 6.1), were counted at 7 days, by 2 observers, blinded for all clinical data and each other's countings. Endothelial phenotype of clusters was confirmed in all patient EPC cultures by uptake of Dil-labelled acetylated LDL (CellSystems Biotechnologie Vertrieb, St. Katharinen, Germany) and binding of UEA-lectin (Sigma-Aldrich, Zwijndrecht, The Netherlands); as described by Hristov et al. ${ }^{17}$ We expressed cluster counts as averages of the duplex measurements for comparison between observers, and as overall average for further data analysis. The interobserver agreement (as measured by intraclass correlation ${ }^{18}$ ) of this method was high: correlations were higher than $0.9(p<0.001)$.

To determine the phenotypes of ECFC and CFU-EC suggested by Yoder et al. ${ }^{16}$, we used flow cytometry in a selection of patients $(n=3)$. Cells were detached, washed with PBS, incubated for 30 minutes at $4^{\circ} \mathrm{C}$ with the following antibodies: PerCP-anti-CD3, APCanti-CD4, PE-anti-CD14, FITC-anti-CD31, PE-anti-CD144, (all from BD Biosciences), and PE-anti-KDR (R\&D Systems), washed with PBS and counted with FACSCalibur (BD Biosciences) and analyzed using CellQuest Software (BD Biosciences).

For cultures with patient or healthy control serum, procedures were identical, except we added $10 \%$ of heat inactivated human serum and omitted the fetal calf serum. We chose this lower concentration after a titration experiment which showed no difference in EPC growth in 10 or $20 \%$ human serum. Note that we did not pool sera for the present study, but assessed effects on EPC outgrowth for each serum sample separately. All patient sera were tested on healthy EPC as isolated from one single healthy donor. 


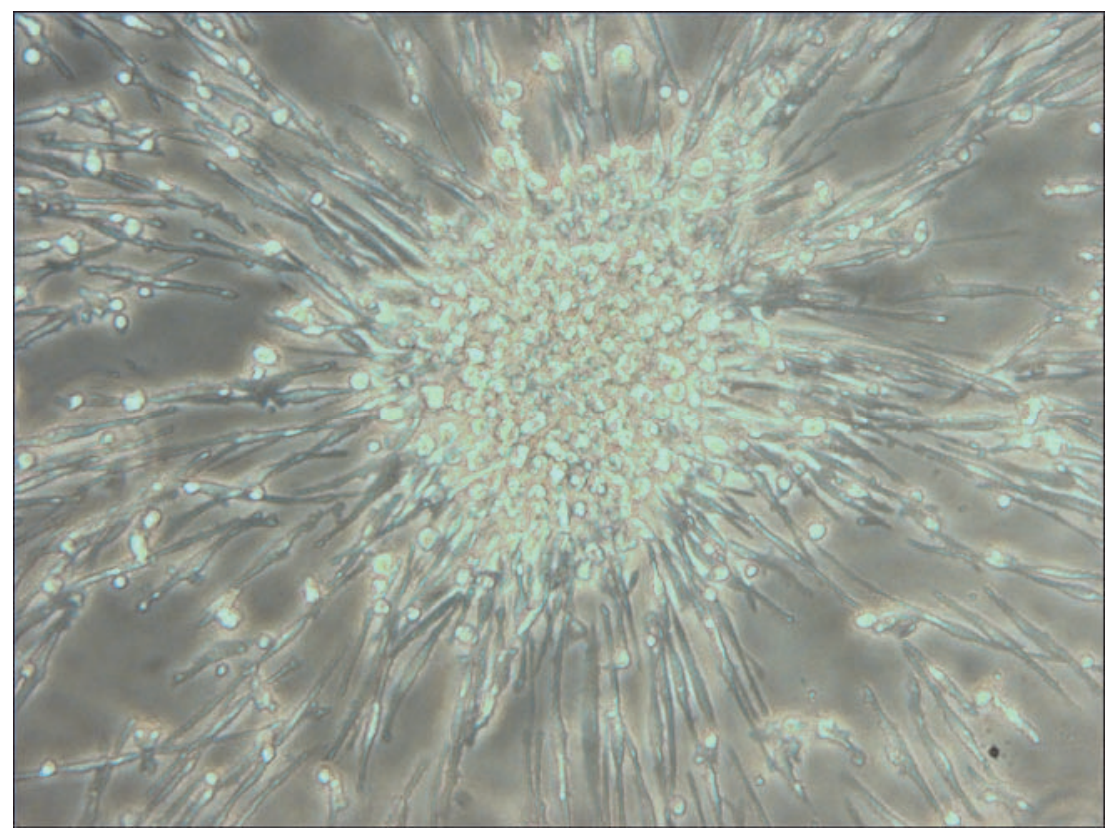

Figure 6.1 Example of an EPC cluster.

\section{Determination of Hpt phenotype}

Hpt phenotypes were determined by using starch gel electrophoresis of haemoglobinsupplemented serum, followed by peroxidase staining, according to Smithies ${ }^{19}$ as described earlier. ${ }^{20}$

\section{Purification of Hpt}

Hpt was purified similar to previously described methods with some minor modifications. ${ }^{21}$ First, haemoglobin was purified from freshly collected blood from a volunteer in EDTA containers (BD Biosciences). After centrifugation and aspiration of plasma, red blood cells were washed three times in phosphate buffered saline (with $0.15 \mathrm{M} \mathrm{NaCl}$ and $10 \mathrm{mM}$ phosphate, $\mathrm{pH} \mathrm{7.4)}$ and lysed in deionized water at $4^{\circ} \mathrm{C}$. After removal of cell debris by centrifugation at $3500 \mathrm{~g}$ for 30 minutes, haemoglobin was fractionated by adding one volume of saturated ammonium sulphate $\mathrm{pH} 7$ at $4^{\circ} \mathrm{C}$ for 30 minutes, followed by centrifugation at $4500 \mathrm{~g}$ for 40 minutes at $4^{\circ} \mathrm{C}$ to remove precipitated proteins. The supernatant containing haemoglobin was dialyzed against $0.02 \mathrm{M}$ sodium phosphate, $\mathrm{pH} 8.0$, at $4^{\circ} \mathrm{C}$ overnight and concentrated by ultrafiltration through an Amicon P-10 filter (Millipore, Amsterdam, The Netherlands), prior to column chromatography. A DEAE column, equilibrated with phosphate buffer, was used for purification. Samples with chromatography profile (read at $280 \mathrm{~nm}$ ) 
consistent with haemoglobin were pooled and dialyzed against coupling buffer, $0.1 \mathrm{M}$ sodium carbonate, $0.5 \mathrm{M} \mathrm{NaCl}, \mathrm{pH} 8.3$ at $4^{\circ} \mathrm{C}$.

Second, the haemoglobin was coupled to CNBr-activated Sepharose-4B (GE Healthcare, Hoevelaken, the Netherlands) After swelling and washing of the gel in $1 \mathrm{mM} \mathrm{HCl}$ at $4{ }^{\circ} \mathrm{C}$, it was added to the predialyzed haemoglobin and stirred gently for two hours at room temperature. After coupling, the gel was centrifuged and the supernatant, containing the uncoupled haemoglobin, was removed. To saturate remaining active sites of Sepharose, the gel was incubated in $0.2 \mathrm{M}$ glycine $\mathrm{pH} 8.0$ for another two hours, after which the gel was washed alternatingly with coupling buffer and acetate buffer ( $0.1 \mathrm{M}$ sodium acetate, $0.5 \mathrm{M} \mathrm{NaCl}, \mathrm{pH} 4.0$ ) and finally with PBS $\mathrm{pH}$ 7.4 .

Third, glass columns (BioRad, Veenendaal, The Netherlands) were packed with $2 \mathrm{~mL}$ haemoglobin-Sepharose and patient serum samples $(2.2 \mathrm{~mL})$ were loaded onto them. Due to its high affinity for haemoglobin, all $\mathrm{Hpt}$ binds to the gel, whereas the remaining serum proteins diffuse through the column. Thus Hpt depleted serum was recovered from the column. Prior to elution of the Hpt bound to the column, the column was washed with $0.15 \mathrm{M} \mathrm{NaCl} \mathrm{pH} 11$ and subsequently eluted in $0.15 \mathrm{M} \mathrm{NaCl}, \mathrm{pH} 11$ with 5 $\mathrm{M}$ urea. This fraction was collected in a tube containing $1 \mathrm{M} \mathrm{Tris-} \mathrm{HCl} \mathrm{pH} 7.0$ to immediately neutralize the $\mathrm{pH}$ value. These fractions were dialyzed against PBS at $4^{\circ} \mathrm{C}$ overnight before use.

\section{Preparation of culture media for addition of Hpt in EPC cultures}

We randomly selected 8 patient sera from this study. We used the same culture medium as described above, with replacement of the $20 \%$ fetal calf serum by $20 \%$ heat inactivated human serum. For Hpt depleted serum we had to adjust the percentage added to culture serum due to protein loss. Protein concentrations before and after depletion were measured according to Lowry; average loss was $40 \%$. We therefore increased serum percentage to obtain similar protein concentrations in the medium before and after depletion. Before use in culture, culture media were sterilized by filtration (Acrodisc Syringe Filters 0.2 micrometer membrane, Pall Corporation, Ann Arbor, MI, USA).

In three patients, one with 1-1, one with 2-1 and one with 2-2 Hpt, we added Hpt to the depleted serum in physiological concentrations $(1 \mathrm{mg} / \mathrm{mL})$. Hpt $1-1$ and $2-2$ were commercially obtained (Sigma-Aldrich, Zwijndrecht, The Netherlands), Hpt 2-1 was purified as described above.

\section{Hpt in EPC cultures}

ECFC and CFU-EC procedures were identical as described above with the following modifications: we used 96 well plates for culture, and adjusted cell concentration to well surface (200 microliter medium with $4.2 * 10^{6}$ cells). With regard to media the following serum and Hpt additions were used: 1) fetal calf serum: a) pure; b) with Hpt 1-1; c) with Hpt 2-1; and d) with Hpt 2-2. 2) 8 different patient sera separately: a) 
before depletion; and b) after depletion. 3) 3 depleted patient sera (1-1, 2-1, and 2-2 seperately) with extra addition of a) Hpt 1-1; b) Hpt 2-1; and c) Hpt 2-2 in all three patients.

\section{Statistical analysis}

We assessed correlations between EPC counts and clinical parameters by Pearson's R for continuous variables, and by t-tests or Mann-Whitney tests for independent samples (whichever was appropriate) for dichotomous variables. We consequently compared patients and controls with regard to cluster counts and to flow cytometry data (absolute number CD34+/KDR+ cells as well as CD34+-cells) using t-tests and Mann-Whitney tests. Correction for age was tentatively performed using MANOVA (distribution of data was not 'normal'). We further contrasted patients with SIL and patients without SIL and compared cluster counts and flow cytometric data. Finally, paired tests were used to compare both cluster counts in patient serum and healthy control serum, and cluster counts of healthy EPC in patient serum and counts of patient EPC in patient or healthy control serum. All analyses were performed using SPSS version 12.0.1.

\section{Results}

\section{Phenotype of cultured EPC}

Cells in our cultures had endothelial characteristics, as confirmed by lectin uptake and binding of acetylated LDL in up to $90 \%$ of cells. Cells which were either adherent or non-adherent after 48 hours culture were phenotyped further in 3 selected patients with FACS analysis after 7 days of culture. A representative characterization is shown in Figure 6.2.

\section{EPC and clinical parameters}

EPC numbers, as detected by FACS analysis, did not relate to the parameters such as age, blood pressure, CRP or cholesterol in the study group. Lower EPC cluster counts (detected as ECFC after 7 days of culture) correlated significantly with higher age but not with other variables such as blood pressure, CRP or cholesterol (see Table 6.2). No correlations were found between EPC numbers as detected by FACS analysis and ECFC or CFU-EC cluster counts after 7 days of culture (Pearson R-square; $p>0.05$ ). 


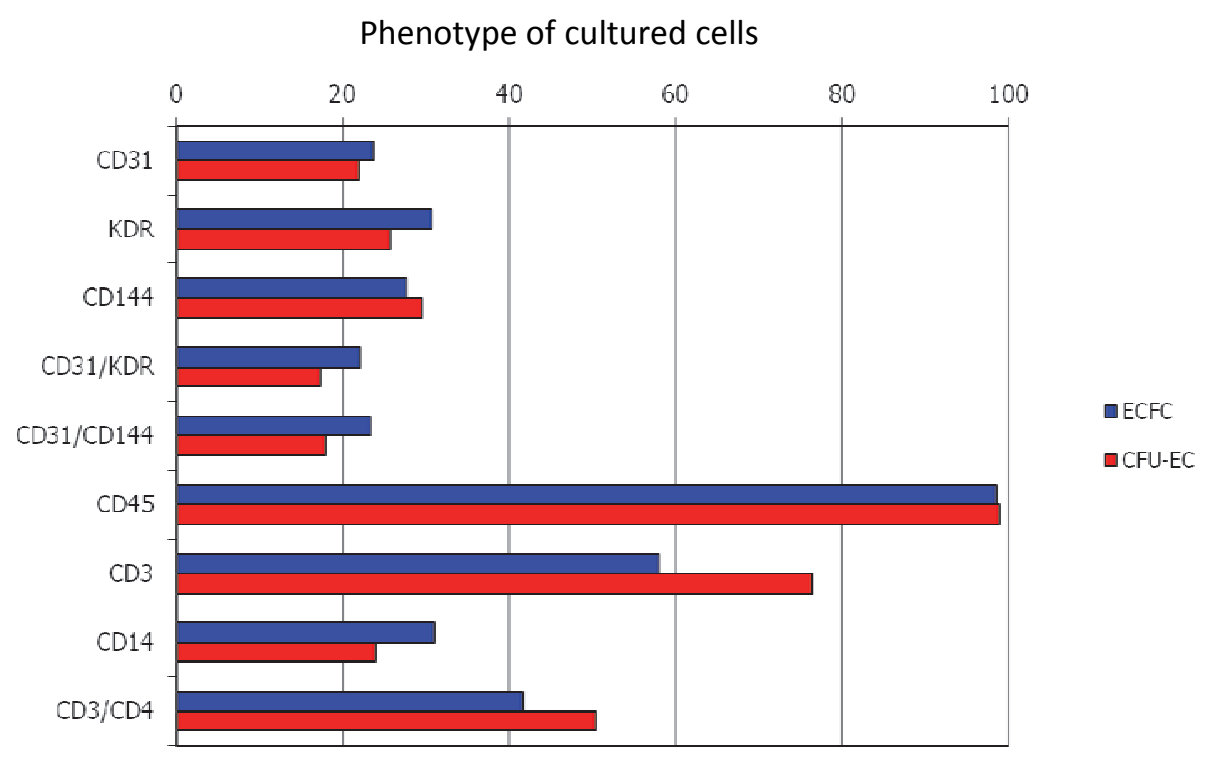

Figure 6.2 Example of a single characterization of cultured cells. Bars indicate percentages of cells positive for the marker designated on the $x$-axis.

\section{EPC in lacunar stroke patients versus controls}

EPC numbers (defined as CD34+/KDR+-cells) did not differ between lacunar stroke patients and controls (Table 6.3). Also, progenitor cells in general (CD34+-cells) did not differ between patients and controls. However, EPC cluster formation as measured by ECFC counts was significantly decreased in patients when compared to controls (Table 6.3). Also, CFU-EC cluster counts were lower in patients than in controls. This difference persisted after correction for age in CFU-EC. When ECFC cluster counts were corrected for age, the p-value changed to 0.06 . 


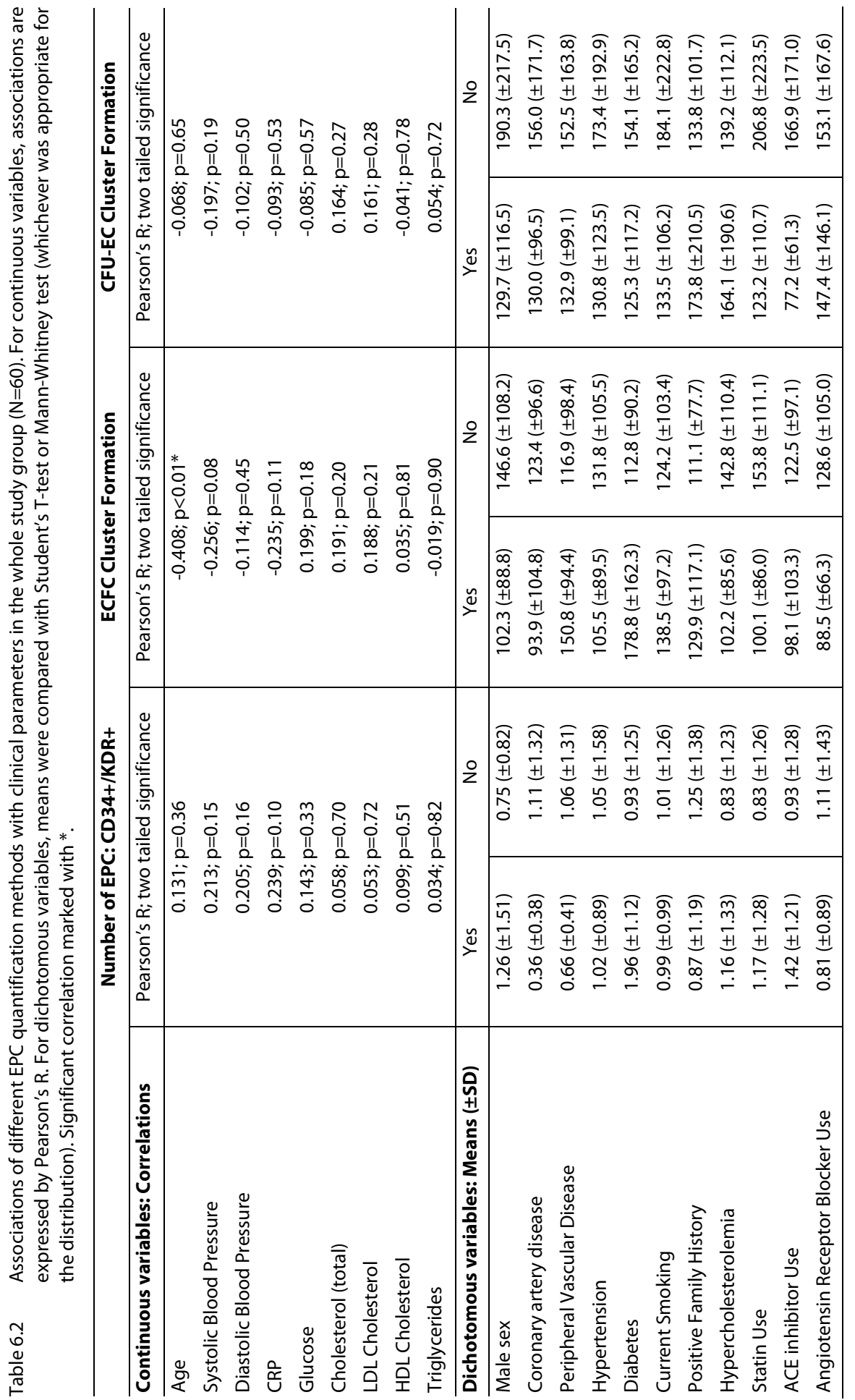


Table 6.3 EPC numbers and cluster counts in lacunar stroke patients and healthy controls. Lacunar stroke patients also divided into patients with silent ischemic lesions and those without. Significant differences as indicated.

\begin{tabular}{|c|c|c|c|c|}
\hline & $\begin{array}{l}\text { Controls } \\
(n=18)\end{array}$ & $\begin{array}{l}\text { Lacunar stroke } \\
\text { patients }(n=42)\end{array}$ & $\begin{array}{l}\text { Patients with } \\
\text { SIL }(n=29)\end{array}$ & $\begin{array}{l}\text { Patients without } \\
\text { SIL }(n=13)\end{array}$ \\
\hline $\begin{array}{l}\mathrm{CD} 34+\left(\text { in } 10^{6}\right. \\
\text { cells } / \mathrm{mL} ; \\
\text { mean } \pm \text { SD) }\end{array}$ & $1.1 \pm 0.97$ & $1.2 \pm 2.20$ & $1.5 \pm 2.59$ & $0.40 \pm 0.39$ \\
\hline $\begin{array}{l}\text { CD34+/KDR+ (in } 10^{3} \\
\text { cells } / \mathrm{mL} \text {; } \\
\text { mean } \pm \mathrm{SD} \text { ) }\end{array}$ & $0.82 \pm 1.33$ & $1.15 \pm 1.24$ & $1.21 \pm 1.26$ & $0.92 \pm 1.23$ \\
\hline $\begin{array}{l}\text { ECFC (clusters/well; } \\
\text { mean } \pm S D \text { ) }\end{array}$ & $174.4 \pm 112.2$ & $\begin{array}{r}96.9 \pm 83.4 \\
\pm \\
\end{array}$ & $85.0 \pm 64.3$ & $125.6 \pm 117.0$ \\
\hline $\begin{array}{l}\text { CFU-EC } \\
\text { (clusters/well; } \\
\text { mean } \pm \text { SD) }\end{array}$ & $\begin{array}{c}235.5 \pm 239.2 \dagger \\
\mathrm{L}\end{array}$ & $\begin{array}{c}119.6 \pm 107.0 \\
\S \\
\end{array}$ & $118.8 \pm 112.9$ & $121.5 \pm 96.6$ \\
\hline
\end{tabular}

*: $p=0.01,+: p=0.03, \ddagger: p=0.02, \S: p=0.05$.

Note: for CD34+ there was a trend to difference between patients with SIL and patients without SIL $(p=0.06)$

\section{EPC and silent ischemic lesions}

EPC numbers, as detected by FACS analysis by the presence of CD34 and KDR, did not differ significantly between patients with SIL $(n=29)$ and controls $(n=18)$. CD34 positive progenitor cells tended to differ between patients with SIL, who had slightly higher numbers of these cells, and patients without SIL $(p=0.06)$. More importantly, however, ECFC counts were significantly lower in patients with silent lesions than in controls, whereas CFU-EC were also lower in patients than in controls. ECFC or CFU-EC counts did not differ between patients without SIL $(n=13)$ and controls (see Table 6.3).

\section{Lacunar stroke patient serum and CFU-EC cluster formation}

When EPC from lacunar stroke patients were cultured with autologous patient serum, lower CFU-EC cluster counts were found than with fetal calf serum (32.0 CFU-EC/well \pm 44.3 CFU-EC/well versus 83.5 /well \pm 46.2 /well; $p<0.001$ ). The CFU-EC cluster formation of patient EPC, however, was not different when cultured in the presence of serum from a healthy donor when compared with fetal calf serum. CFU-EC cluster counts of healthy donor EPC were also lower in cultures with patient serum than in those with heterologous healthy donor serum or fetal calf serum (See Figure 6.3). ECFC cluster formation of patients and healthy controls did not differ when cultured in the presence of patient serum, healthy control serum, or fetal calf serum. 


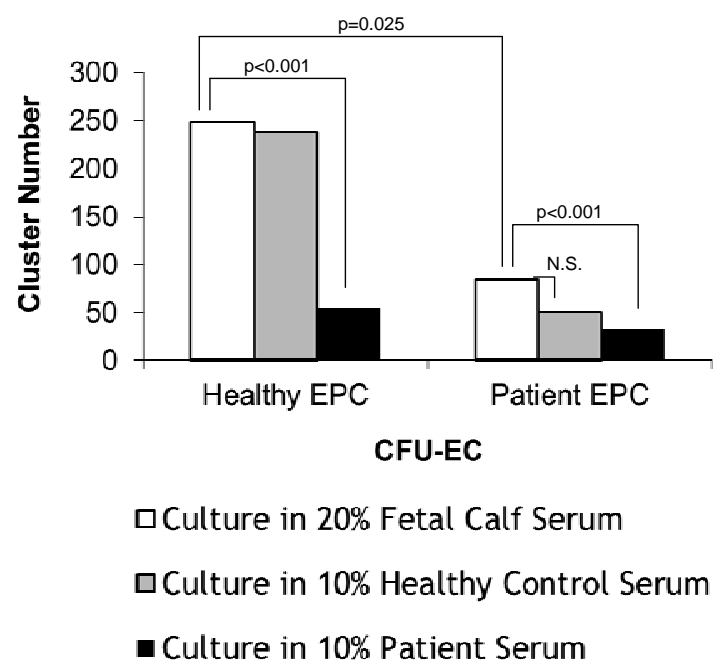

Figure 6.3 Cluster counts of cells which were non-adherent after 48 hours (Endothelial Cell Colony Forming Units (CFU-EC)), counted after 7 days. First three bars: CFU-EC cluster formation from EPC of a single healthy donor. Bars are based on three independent duplicate measurement for fetal calf serum (white bar), three measurements for (autologous) healthy control serum (grey bar) and twenty-nine lacunar stroke patient sera (black bar). Last three bars: average CFU-EC cluster formation from EPC of lacunar stroke patients $(n=15)$, in fetal calf serum (white bar), in healthy control serum (grey bar), and autologous patient serum (black bar). Significant differences are indicated.

\section{Serum of patients with SIL and CFU-EC cluster formation of healthy donor EPC}

CFU-EC cluster counts of healthy donor EPC were lower if cultured in the presence of SIL patient serum ( $n=22 ; 40.2 \mathrm{CFU}-\mathrm{EC} /$ well $\pm 26.5 \mathrm{CFU}-\mathrm{EC} /$ well) than if cultured in the presence of non-SIL patient serum ( $n=7 ; 92.1 \mathrm{CFU}-\mathrm{EC} /$ well $\pm 55.4 \mathrm{CFU}-\mathrm{EC} /$ well; $p=0.049)$. CFU-EC cluster formation of healthy EPC in patient serum did not correlate with blood glucose, CRP or cholesterol, HDL or LDL levels in the patient serum.

\section{EPC cluster formation and Hpt phenotype}

To assess whether an inhibitory effect of patient serum on healthy CFU-EC cluster formation was due to Hpt we cultured cells in $20 \%$ full patient serum and Hpt depleted serum. CFU-EC counts tended to be higher in depleted serum $(305.1 \pm 171.1)$ than in non-depleted serum (183.2 $\pm 139.5 ; n=8$, (paired) Wilcoxon-test; $p=0.064)$ We hypothesized that the effect of $\mathrm{Hpt}$ depletion did not reach statistical significance because of a differential effect of the different Hpt phenotypes. To assess whether this effect differed between the three different phenotypes of $\mathrm{Hpt}$, we determined $\mathrm{Hpt}$ phenotype in relation to CFU-EC cluster formation. Patients with Hpt 1-1 (n=8) had significantly lower CFU-EC cluster counts (median 37.9 interquartile range 45.4 ) than 


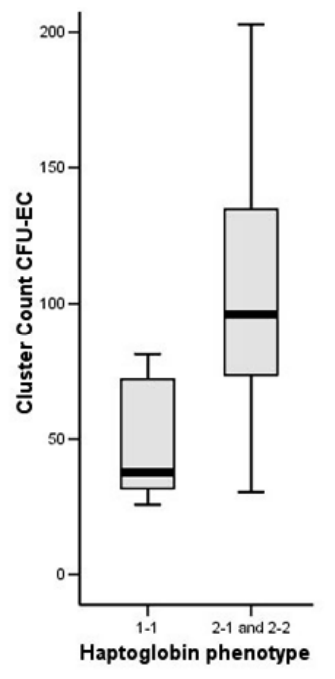

Figure 6.4 Haptoglobin and CFU-EC cluster formation. CFU-EC Cluster counts in patients with haptoglobin phenotype 1-1 are significantly lower than those with 2-1 or 2-2; Mann Whitney U test, $\mathrm{p}=0.02$. patients with 2-1 and 2-2 ( $n=21$; median 96.3, interquartile range 94.6; $p=0.02$; see Figure 6.4). In vitro, we added purified Hpt protein to our standard culture medium. Healthy CFU-EC cluster formation was strikingly lower in medium with Hpt 1-1 but also with Hpt 2-1 (Figure 6.5). We also added the three different $\mathrm{Hpt}$ proteins to Hpt depleted patient serum of three different patients, with originally Hpt 11, 2-1 and 2-2. Again, healthy CFU-EC cluster formation was strikingly lower in medium containing $\mathrm{Hpt}$ 1-1 as compared to $\mathrm{Hpt}$ depleted serum, regardless of the original Hpt phenotype of the Hpt depleted patient serum to which the Hpt 1-1 was added (Figure 6.5). For all mentioned tests healthy ECFC cluster formation was not significantly different between Hpt phenotypes.

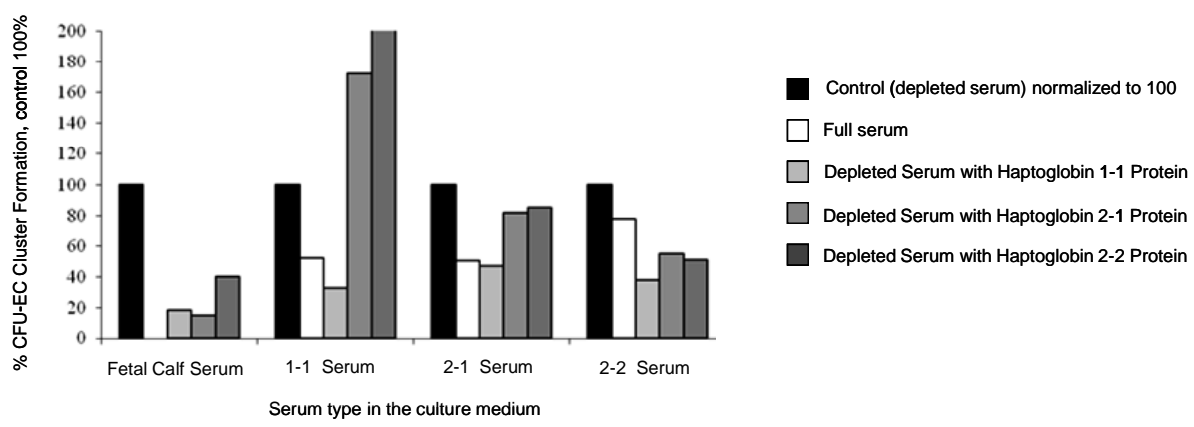

Figure 6.5 Effect of the three different haptoglobin phenotypes on CFU-EC cluster formation of one healthy donor. First bars indicate CFU-EC cluster formation after 7 days in culture medium with haptoglobin depleted serum. Second bars indicate cluster formation in culture medium with full patient serum whereas bars 3 to 5 indicate cluster formation in culture medium with haptoglobin depleted serum and subsequent supplementation with haptoglobin 1-1, 2-1, and $2-2$, respectively. Addition of haptoglobin 1-1 results in lowest values for CFU-EC cluster formation. Statistical analyses not performed due to nature of measurements. 


\section{Discussion}

In this study we found that absolute EPC numbers, as measured by flow cytometry, did not differ between lacunar stroke patients and controls. In contrast, EPC cluster numbers, as measured after 7 days of culture, were significantly lower in patients. Moreover, in lacunar stroke patients with additional silent ischemic lesions cluster counts were even lower than those in lacunar stroke patients without such lesions. These findings indicate that EPC cluster formation is impaired in patients with lacunar stroke, and even more so in lacunar stroke patients with concomitant silent ischemic lesions. Moreover, as CD34+-progenitor cell numbers tend to be higher in patients with silent ischemic lesions, cluster formation may be proportionally even more deficient.

In two prognostic studies in patients with coronary artery disease, lower EPC cluster formation related to more cardiovascular events during follow-up. ${ }^{6,22}$ Migraine patients have lower EPC cluster formation than tension type headache patients, and also in this patient group, EPC cluster formation relates to the Framingham Risk Score. ${ }^{23}$ In stroke, however, there are only few studies on EPC cluster formation and prognosis. Ghani et al. showed that EPC cluster number (ECFC variant) were lower in stroke patients than in healthy controls. ${ }^{7}$ Chu et al. ${ }^{9}$ confirmed these results by using another culture technique in which cells were left to adhere for 7 days (this method leaves no room for differentiation into ECFC or CFU-EC). They also demonstrated that EPC cluster numbers differed between stroke subtypes: patients with cardioembolic stroke had higher numbers than patients with large or small vessel stroke. ${ }^{9}$ Sobrino et al. showed that EPC cluster numbers (CFU-EC variant) rose in 25 (non-lacunar) stroke patients with good outcome in the first three months after their stroke. ${ }^{8}$ In all these studies EPC cluster formation after culture was assessed without the simultaneous measurement of EPC numbers as detected by flow cytometry. Therefore, it is unknown whether cluster formation was reduced as a consequence of lower absolute EPC numbers or as a consequence of functional deficits in the EPC. On the other hand, Taguchi et al. ${ }^{24}$ counted progenitor cell numbers (CD34+-cells) in 5 stroke patients, and demonstrated a rise 7 days after the stroke. Similarly, Yip et al. $^{25}$ found that CD34/KDR+-cells were increased after 2 days in stroke patients and demonstrated that a higher CD34/KDR+-proportion within the total leukocyte count related to a better clinical recovery 90 days after stroke. However, these authors did not perform culture assays to assess the cluster formation potential. All these studies point to a possible role of EPC in the acute pathophysiological process after ischemic stroke. However, they do not allow conclusions with regard to processes of EPC recruitment and/or regulation of EPC cluster formation as these studies were observational in character. Therefore, by the simultaneous measurement of the absolute number by flow cytometry as well as the cluster formation potential, our study shows that lacunar stroke patients most likely have an impaired EPC function, which is not due solely to a lower EPC number. 
Our second important finding was that cluster formation was impaired when we added serum of patients with SIL to cultures of healthy and/or patient EPC. These findings indicate that one (or more) inhibitory factors on EPC cluster formation may be present, or that enhancing factors for EPC cluster formation may be deficient in the serum of patients with SIL. From our in vitro studies, we suggest that the Hpt phenotype 1-1 is a likely candidate for this effect. Previously, we demonstrated that the Hpt 1 allele related to white matter lesions, and that $\mathrm{Hpt}$ 2-2 was significantly less frequent among lacunar stroke patients than in controls. ${ }^{11}$ In the present study, we demonstrated that patients with Hpt 1-1 had lowest CFU-EC cluster counts (Figure 6.4). Furthermore, Hpt 1-1 related to the lowest CFU-EC cluster numbers after its addition to Hpt free culture medium, as compared to the other Hpt types (Figure 6.5). The potent angiogenic properties of Hpt 2-2 (which are higher than those of Hpt 1-1), as demonstrated in animal models of cardial ischemia, ${ }^{12}$ could be key to the understanding of the relation between SIL, Hpt 1-1 and low CFU-EC cluster numbers. A defective blood-brain barrier as a consequence of endothelial dysfunction is probably involved in the pathogenesis of SIL. Because EPC restore endothelial function, ${ }^{26}$ an impaired EPC response could in this way lead to the development of cerebral small vessel disease and SIL. Moreover, the relation between lower EPC cluster counts and silent white matter lesions may be mediated by the absence of Hpt 2-2, because Hpt 2-2 relates to angiogenic potential, and cerebral small vessel integrity may especially depend on this potential. Thus, the Hpt 2-2 phenotype might offer protection from cerebral small vessel disease by its angiogenic properties and stimulation of EPC.

Other well-defined serum factors, which are already known to attenuate EPC cluster formation, are CRP, ${ }^{27}$ and low density lipoprotein (LDL). ${ }^{28}$ In a study with serum of patients with renal insufficiency, Westerweel et al. ${ }^{29}$ demonstrated that healthy EPC cluster formation was attenuated. They suggested that this effect was due to the uraemia. In our study CRP and LDL values did not differ between SIL and non-SIL patients, and none of our patients was uraemic (data not shown). Alternatively, the absence of a beneficial factor may have resulted in decreased EPC cluster formation in our patients. Statins enhance EPC function in vitro. ${ }^{30}$ Since nearly all our lacunar stroke patients used statins, and SIL as well as non-SIL patients used them equally, it is unlikely that statins account for the differences found in inhibition of healthy EPC outgrowth between these groups.

Yoder et al. $^{16}$ recently described two different EPC populations which can be distinguished in culture: CFU-EC and ECFC. The first population possesses regulating, angiogenic properties, and the second matures into endothelial cells. For both the ECFC as well as the CFU-EC population, cluster numbers were lower in our lacunar stroke patients. However, only CFU-EC were attenuated in their cluster formation by SIL patient serum. Previously, several investigators showed that impaired CFU-EC cluster formation was related to an increased rate of cardiovascular events and a poorer prognosis. ${ }^{6,8}$ We postulate that modulation of the function of these cells in patients with silent ischemic lesions (who have increased risk of recurrent stroke and 
(vascular) cognitive decline) $)^{2,31-33}$ especially in the presence of haptoglobin 1-1, may find a place in improving the prognosis, including the mitigation of the vascular contribution to the development of cognitive decline and dementia.

Our study has some drawbacks. First, our lacunar stroke patients had a slightly more extensive vascular history than our controls. In statistical analyses, correction is only possible to a certain extent. However, our lacunar stroke patients with concomitant SIL and those without SIL did not differ in vascular history. It is therefore unlikely that comparisons between these groups are biased by vascular risk factors. Second, our study, as well as all other studies regarding EPC, used non-standardized methods to detect these cells. This could lead to assessment of other cell types, which are not EPC. Recently, a new protocol for EPC flow cytometry has been published, ${ }^{34}$ but other quantification techniques, like ours, are also widely used. ${ }^{5,6}$ For cultures, we used a protocol similar to that of Yoder et al. ${ }^{16}$ However, we could confirm that the cells we cultured were (at least partly) of endothelial phenotype. Third, the lack of correlation between flow cytometric counting and cluster counts could indicate a defective technique in one or both circumstances. However, this lack of correlation was previously also found by others, ${ }^{35}$ and therefore, it only reflects the different EPC characteristics which are measured by flow cytometry (EPC number) and culture (EPC function). ${ }^{10}$ Fourth, as the clinical part in our study is purely observational, the associations between lower EPC vitality and lacunar stroke and SIL cannot be automatically regarded as causal. However, the experimental part of our study shows the attenuation of CFU-EC cluster growth by haptoglobin 1-1. Fifth, as our study group only consisted of patients with small vessel stroke, our findings cannot be generalized to other stroke subtypes such as large vessel stroke, cardioembolic brain infarct, or cerebral hemorrhage. However, such generalization may be undesirable, as SIL are caused by cerebral small vessel disease.

In conclusion, our study is the first to show that EPC cluster formation is impaired in lacunar stroke patients. Moreover, in patients with concomitant silent ischemic lesions EPC cluster formation is impaired even further. Our data also indicate that it is most likely that haptoglobin is one of the factors in serum which is responsible for this effect. As EPC cluster formation relates to vascular prognosis, the identification of haptoglobin phenotype, and its potential up- or downregulatory mechanisms, could open new avenues for the treatment of cerebral small vessel disease and its consequences among which is cognitive decline. 


\section{References}

1. Vermeer SE, Longstreth WT, Jr., Koudstaal PJ. Silent brain infarcts: a systematic review. Lancet Neurol. 2007;6:611-619

2. de Jong G, Kessels F, Lodder J. Two types of lacunar infarcts: further arguments from a study on prognosis. Stroke. 2002;33:2072-2076

3. Farrall AJ, Wardlaw JM. Blood-brain barrier: ageing and microvascular disease - systematic review and meta-analysis. Neurobiol Aging. 2009;30:337-352

4. Wardlaw JM, Sandercock PA, Dennis MS, Starr J. Is breakdown of the blood-brain barrier responsible for lacunar stroke, leukoaraiosis, and dementia? Stroke. 2003;34:806-812

5. Hill JM, Zalos G, Halcox JP, Schenke WH, Waclawiw MA, Quyyumi AA, Finkel T. Circulating endothelial progenitor cells, vascular function, and cardiovascular risk. N Engl J Med. 2003;348:593-600

6. Werner N, Kosiol S, Schiegl T, Ahlers P, Walenta K, Link A, Bohm M, Nickenig G. Circulating endothelial progenitor cells and cardiovascular outcomes. N Engl J Med. 2005;353:999-1007

7. Ghani U, Shuaib A, Salam A, Nasir A, Shuaib U, Jeerakathil T, Sher F, O'Rourke F, Nasser AM, Schwindt $B$, Todd K. Endothelial progenitor cells during cerebrovascular disease. Stroke. 2005;36:151-153

8. Sobrino T, Hurtado O, Moro MA, Rodriguez-Yanez M, Castellanos M, Brea D, Moldes O, Blanco M, Arenillas JF, Leira R, Davalos A, Lizasoain I, Castillo J. The increase of circulating endothelial progenitor cells after acute ischemic stroke is associated with good outcome. Stroke. 2007;38:2759-2764

9. Chu K, Jung KH, Lee ST, Park HK, Sinn DI, Kim JM, Kim DH, Kim JH, Kim SJ, Song EC, Kim M, Lee SK, Roh JK. Circulating endothelial progenitor cells as a new marker of endothelial dysfunction or repair in acute stroke. Stroke. 2008;39:1441-1447

10. Rouhl RPW, van Oostenbrugge RJ, Damoiseaux J, Cohen Tervaert JW, Lodder J. Endothelial progenitor cell research in stroke: a potential shift in pathophysiological and therapeutical concepts. Stroke. 2008;39:2158-2165

11. Staals J, Pieters BMA, Knottnerus ILH, Rouhl RPW, van Oostenbrugge RJ, Delanghe JR, Lodder J. Haptoglobin polymorphism and lacunar stroke. Curr Neurovasc Res. 2008;5:153-158

12. Lohr NL, Warltier DC, Chilian WM, Weihrauch D. Haptoglobin expression and activity during coronary collateralization. Am J Physiol Heart Circ Physiol. 2005;288:H1389-1395

13. Rouhl RP, van Oostenbrugge RJ, Knottnerus IL, Staals JE, Lodder J. Virchow-Robin spaces relate to cerebral small vessel disease severity. J Neurol. 2008;255:692-696

14. Fazekas F, Chawluk JB, Alavi A, Hurtig HI, Zimmerman RA. MR signal abnormalities at $1.5 \mathrm{~T}$ in Alzheimer's dementia and normal aging. AJR Am J Roentgenol. 1987;149:351-356

15. Khan SS, Solomon MA, McCoy JP, Jr. Detection of circulating endothelial cells and endothelial progenitor cells by flow cytometry. Cytometry B Clin Cytom. 2005;64:1-8

16. Yoder MC, Mead LE, Prater D, Krier TR, Mroueh KN, Li F, Krasich R, Temm CJ, Prchal JT, Ingram DA. Redefining endothelial progenitor cells via clonal analysis and hematopoietic stem/progenitor cell principals. Blood. 2007;109:1801-1809

17. Hristov M, Fach C, Becker C, Heussen N, Liehn EA, Blindt R, Hanrath P, Weber C. Reduced numbers of circulating endothelial progenitor cells in patients with coronary artery disease associated with longterm statin treatment. Atherosclerosis. 2007;192:413-420

18. Bartko JJ. Measurement and reliability: statistical thinking considerations. Schizophr Bull. 1991;17: 483-489

19. Smithies O. Zone electrophoresis in starch gels: group variations in the serum proteins of normal human adults. Biochem J. 1955;61:629-641

20. Depypere HT, Langlois MR, Delanghe JR, Temmerman M, Dhont M. Haptoglobin polymorphism in patients with preeclampsia. Clin Chem Lab Med. 2006;44:924-928

21. Liau CY, Chang TM, Pan JP, Chen WL, Mao SJ. Purification of human plasma haptoglobin by hemoglobin-affinity column chromatography. J Chromatogr B Analyt Technol Biomed Life Sci. 2003;790:209-216

22. Schmidt-Lucke C, Rossig L, Fichtlscherer S, Vasa M, Britten M, Kamper U, Dimmeler S, Zeiher AM. Reduced number of circulating endothelial progenitor cells predicts future cardiovascular events: proof of concept for the clinical importance of endogenous vascular repair. Circulation. 2005;111:2981-2987 
23. Lee ST, Chu K, Jung KH, Kim DH, Kim EH, Choe VN, Kim JH, Im WS, Kang L, Park JE, Park HJ, Park HK, Song EC, Lee SK, Kim M, Roh JK. Decreased number and function of endothelial progenitor cells in patients with migraine. Neurology. 2008;70:1510-1517

24. Taguchi A, Matsuyama T, Moriwaki H, Hayashi T, Hayashida K, Nagatsuka K, Todo K, Mori K, Stern DM, Soma T, Naritomi H. Circulating CD34-positive cells provide an index of cerebrovascular function. Circulation. 2004;109:2972-2975

25. Yip HK, Chang LT, Chang WN, Lu CH, Liou CW, Lan MY, Liu JS, Youssef AA, Chang HW. Level and value of circulating endothelial progenitor cells in patients after acute ischemic stroke. Stroke. 2008;39:69-74

26. Urbich C, Dimmeler S. Endothelial progenitor cells: characterization and role in vascular biology. Circ Res. 2004;95:343-353

27. Verma S, Kuliszewski MA, Li SH, Szmitko PE, Zucco L, Wang CH, Badiwala MV, Mickle DA, Weisel RD, Fedak PW, Stewart DJ, Kutryk MJ. C-reactive protein attenuates endothelial progenitor cell survival, differentiation, and function: further evidence of a mechanistic link between C-reactive protein and cardiovascular disease. Circulation. 2004;109:2058-2067

28. Pellegatta F, Bragheri M, Grigore L, Raselli S, Maggi FM, Brambilla C, Reduzzi A, Pirillo A, Norata GD, Catapano AL. In vitro isolation of circulating endothelial progenitor cells is related to the high density lipoprotein plasma levels. Int J Mol Med. 2006;17:203-208

29. Westerweel PE, Hoefer IE, Blankestijn PJ, de Bree P, Groeneveld D, van Oostrom O, Braam B, Koomans $H A$, Verhaar MC. End-stage renal disease causes an imbalance between endothelial and smooth muscle progenitor cells. Am J Physiol Renal Physiol. 2007;292:F1132-1140

30. Assmus B, Urbich C, Aicher A, Hofmann WK, Haendeler J, Rossig L, Spyridopoulos I, Zeiher AM, Dimmeler S. HMG-CoA reductase inhibitors reduce senescence and increase proliferation of endothelial progenitor cells via regulation of cell cycle regulatory genes. Circ Res. 2003;92:1049-1055

31. Prins ND, van Dijk EJ, den Heijer T, Vermeer SE, Jolles J, Koudstaal PJ, Hofman A, Breteler MM. Cerebral small-vessel disease and decline in information processing speed, executive function and memory. Brain. 2005;128:2034-2041

32. Prins ND, van Dijk EJ, den Heijer T, Vermeer SE, Koudstaal PJ, Oudkerk M, Hofman A, Breteler MM. Cerebral white matter lesions and the risk of dementia. Arch Neurol. 2004;61:1531-1534

33. Vermeer SE, Hollander M, van Dijk EJ, Hofman A, Koudstaal PJ, Breteler MM. Silent brain infarcts and white matter lesions increase stroke risk in the general population: the Rotterdam Scan Study. Stroke. 2003;34:1126-1129

34. Duda DG, Cohen KS, Scadden DT, Jain RK. A protocol for phenotypic detection and enumeration of circulating endothelial cells and circulating progenitor cells in human blood. Nat Protoc. 2007;2: $805-810$

35. Tura O, Barclay GR, Roddie H, Davies J, Turner ML. Absence of a relationship between immunophenotypic and colony enumeration analysis of endothelial progenitor cells in clinical haematopoietic cell sources. J Transl Med. 2007;5:37 



\section{Chapter 7}

Angiogenic T-cells and putative endothelial progenitor cells in hypertension related cerebral small vessel disease

Rouhl RPW

Mertens AECS

van Oostenbrugge RJ

Damoiseaux JGMC

Debrus-Palmans LL

Henskens LHG

Kroon AA

de Leeuw PW

Lodder J

Cohen Tervaert JW

Stroke 2012;43:256-258 


\section{Abstract}

\section{Background and purpose}

Cerebral small vessel disease (CSVD) may be caused by endothelial dysfunction, whereas endothelial progenitor cells (EPC) may attenuate endothelial dysfunction. Their vitality is lower in CSVD. A subset of lymphocytes, angiogenic T-cells, is capable to stimulate EPC function. The purpose of our study was to explore the relation between CSVD manifestations, angiogenic T-cells, and EPC in hypertensive patients with CSVD.

\section{Methods}

We compared 32 essential hypertensive patients with CSVD (white matter lesions, asymptomatic lacunar infarcts or microbleeds on 1.5 Tesla MRI) to 29 age- and sexmatched hypertensive controls. We counted angiogenic T-cells $\left(\mathrm{CD} 3^{+} / \mathrm{CD} 31^{+} / \mathrm{CD} 184^{+}\right)$ and putative EPC $\left(\mathrm{CD} 31^{+} / \mathrm{CD} 34^{+} / \mathrm{CD}^{-} 5^{-} / \mathrm{KDR}^{+}\right)$by flow cytometry, and determined EPC vitality by in vitro cluster formation.

\section{Results}

Putative EPC numbers were lower in hypertensives with CSVD than in those without $\left(10 \pm 710^{3} / \mathrm{mL}\right.$ versus $13 \pm 6 \cdot 10^{3} / \mathrm{mL}$; (median \pm interquartile range), $p=0.011$ ). Angiogenic T-cell numbers were also lower in hypertensives with CSVD than in those without $\left(0.56 \pm 0.2510^{9} / \mathrm{mL}\right.$ versus $\left.0.78 \pm 0.5010^{9} / \mathrm{mL} ; \mathrm{p}=0.008\right)$. Higher angiogenic T-cell numbers independently related to absence of CSVD (OR 0.088; 95\%-CI 0.012-0.627).

\section{Conclusions}

Our data suggest that angiogenic T-cells and putative EPC independently relate to radiological CSVD manifestations in hypertensive patients. 


\section{Introduction}

Cerebral Small Vessel disease (CSVD) has several manifestations, such as white matter lesions (WML), lacunar infarcts and microbleeds. Blood-brain barrier dysfunction could play a key role in the pathogenesis of these abnormalities. ${ }^{1}$ Dysfunction of the bloodbrain barrier may be attenuated by putative endothelial progenitor cells (EPC). Putative EPC are immature cells, which circulate in peripheral blood. ${ }^{2}$ They are involved in repair of endothelial damage ${ }^{2}$ and are possibly also involved in improving endothelial cell function. ${ }^{3}$ In CSVD, however, more severely affected patients have lower EPC vitality, ${ }^{4}$ whereas factors which regulate putative EPC in CSVD are largely unknown. $^{2}$

Recent studies suggest that angiogenic T-cells ( $\left.T_{\text {ang }}\right)$ may regulate EPC function. ${ }^{5} T_{\text {ang }}$ express platelet endothelial cell adhesion molecule (CD31) as well as the receptor for stromal derived factor 1 (CD184). ${ }^{5}$ Furthermore, $T_{\text {ang }}$ promote the formation of new blood vessels and endothelial repair by stimulating the function of EPC. ${ }^{5}$

We hypothesized that CSVD patients have lower numbers of $T_{\text {ang, }}$ which may relate to lower EPC vitality. To test this hypothesis, we counted angiogenic T-cells and putative EPC, and measured EPC functional properties in two groups of hypertensive patients, one with and one without CSVD in a case-control design.

\section{Methods}

\section{Patients}

Patients who were referred to the outpatient department of Internal Medicine for the evaluation of their elevated blood pressure were included between July 2004 and September 2006. Patients participated in a longitudinal cohort study on hypertensive organ damage in the brain. ${ }^{6}$ Patients with evidence of secondary hypertension, chronic renal insufficiency, diabetes, heart disease, atrial fibrillation or clinically evident cerebrovascular disease were excluded. ${ }^{6}$ Of the 389 eligible patients, 218 were willing and able to participate in the cohort study.

We selected two groups of patients at their follow-up visit, two years after their original inclusion. At this visit, patients underwent MRI of the brain as well as blood sampling. Fifty-three patients appeared to have CSVD (see below for criteria), and 32 of these participated in our study. In addition, age, sex and medication matched hypertensive control subjects without CSVD from the master study were asked to participate. Unfortunately, three subjects were unable to participate, which left a total of 29 hypertensive controls without CSVD. For the other 21 patients with CSVD there was no age, sex, and medication matched control available in the master study. With regard to their vascular risk factor profiles, these subjects $(n=21)$ did not differ from the subjects with CSVD who were included $(n=32)$. As vascular risk factor profiles, we 
defined diabetes mellitus as known diabetes, treated or not, or fasting serum glucose $>7 \mathrm{mmol} / \mathrm{L}$, or a postprandial glucose level $>11 \mathrm{mmol} / \mathrm{L}$ on at least 2 separate occasions; coronary artery disease as known or treated angina pectoris, myocardial infarction, or typical ECG changes; hypercholesterolemia as known high cholesterol levels, treated or not, or fasting total cholesterol levels of $>5.0 \mathrm{mmol} / \mathrm{L}$; and peripheral vascular disease as known intermittent claudication, leg ischemia at rest, or amputation as a consequence of peripheral vascular disease.

\section{Procedures}

\section{$M R I$ of the brain}

We described our MRI protocol in detail previously. ${ }^{6}$ In short, standard 1.5 Tesla T2weighted, fluid-attenuated inversion-recovery (FLAIR), as well as gradient echo (T2*) sequences were used (Intera, Philips Medical Systems, Best, The Netherlands; scan parameters: 1.5 Tesla, field of view $23 * 23 \mathrm{~cm}$, matrix $512 * 512$, slice thickness $5 \mathrm{~mm}$ and gaps of $0.50 \mathrm{~mm}$ ). Images were assessed by consensus by two experienced neurovascular researchers (R.P.W. Rouhl and R.J. van Oostenbrugge). ${ }^{7}$ We counted lacunar infarcts (with diameter $<20 \mathrm{~mm}$; hyperintense lesions on T2 imaging with corresponding hypointense lesion with hyperintense rim on FLAIR images) and deep and/or superficial microbleeds (small $(<5 \mathrm{~mm})$ hypointensities on gradient echo imaging, not representing calcifications or superficial blood vessels). We used the Fazekas-scale to estimate the extent of the periventricular and deep WML. ${ }^{8}$ Extensive WML were defined as a score of 3 (periventricular hyperintensities with involvement of white matter) on the periventricular scale, and/or a score of 2 or 3 on the deep white matter scale (beginning confluence of lesions or large confluent lesions). Based on these assessments, we defined CSVD (and classified patients) with the presence of one or more of the following: (asymptomatic) lacunar infarcts, extensive white matter lesions or microbleeds.

\section{Blood}

For EPC quantification, $30 \mathrm{~mL}$ blood was sampled after an overnight fast, without the use of a tourniquet, and anticoagulated in heparin (standard $10 \mathrm{~mL}$ tubes, BD Biosciences, Breda, the Netherlands). Serum samples were collected in $5 \mathrm{~mL}$ tubes (BD Biosciences). At the same time, we measured blood pressure by standard sphygmomanometry.

\section{Cell Culture: Measuring EPC cluster formation}

For cell culture, we used two different methods simultaneously. ${ }^{2,3,9}$ In short, peripheral blood mononuclear cells were isolated by density gradient centrifugation (Lymphoprep, Axis, Oslo, Norway) and plated onto gelatin (1\%) coated wells at $4.10^{6}$ cells per well (24 well plates) in $1 \mathrm{~mL}$ of medium (RPMI 1640 Glutamax I; 
Gibco/Invitrogen, Breda, The Netherlands) containing $20 \%$ heat-inactivated fetal calf serum (Integro BV, Lelystad, The Netherlands), $100 \mathrm{IU} / \mathrm{mL}$ penicillin and $100 \mu \mathrm{g} / \mathrm{mL}$ streptomycin (Gibco), heparin (20 IE/mL; Leo Pharma, Breda, The Netherlands) and endothelial growth factors (extracted from bovine hypothalamus). Cells were cultured at $37^{\circ} \mathrm{C}$ and $5 \% \mathrm{CO}_{2}$. After 48 hours, non-adherent cells were detached and replated onto new gelatin coated wells (at $110^{6}$ cells/well). Adherent cells were supplied with fresh medium. Cultures were continued until day 7 for both the initially non-adherent cells (termed Endothelial Cell Colony-Forming Units (CFU-EC)); and the adherent cells (termed Endothelial Colony Forming Cells (ECFC)). All cultures were performed in duplicate. Clusters consisting of round cells, with emanating spindle shaped cells peripherally, were counted at 7 days, by 2 observers, blinded for all clinical data and each other's countings. We expressed cluster counts as average of the duplex measurements counted by two different observers for further data analysis. The interobserver agreement (as measured by intraclass correlation) of this method was high: correlations were higher than $0.9(p<0.001)$.

\section{EPC senescence}

To assess senescence of the cultured cells, cells from the ECFC and CFU-EC cultures were harvested after 7 days of culturing. We used the commercially available telomerase assay TeloTAGGG telomerase PCR ELISA ${ }^{\text {PLUS }}$ (Roche, Almere, The Netherlands). This assay detects telomerase activity with a lower activity denoting cellular senescence. The assay was performed according to the manufacturer's instructions.

\section{Flow cytometry: counting EPC numbers}

To assess EPC numbers, we used the complete protocol previously published by Duda et al. ${ }^{10}$ In short, we separated cells from plasma, and applied Fc-blocking agent (Miltenyi Biotec, Bergisch Gladbach, Germany) before incubating with FITC-anti-CD31, PE-anti-KDR, PerCP-anti-CD34 and APC-anti-CD45 (all from BD Biosciences). While assessing EPC numbers, we adjusted for their low event rate in flow cytometry, ${ }^{11}$ by using IgG isotype controls for all fluorochromes (BD Biosciences). After washing, we counted cells with FACSCalibur (BD Biosciences) and gated mononuclear cells, identifying EPCs as $\mathrm{CD} 31^{+} / \mathrm{CD} 34^{\text {bright }} / \mathrm{CD} 45^{-/ \text {low }} / \mathrm{KDR}^{+}$. We corrected these cell numbers for aspecific binding by subtracting positive cells in isotype controls. 

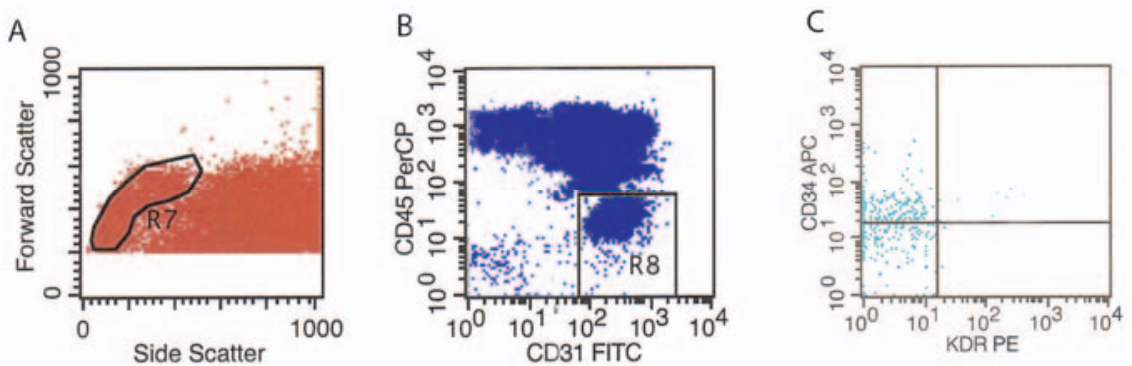

Figure 7.1 Gating strategy used for the flow cytometric enumeration of putative EPC (CD31+/CD34+/CD45-(or low)/KDR+). This analysis was performed by one trained observer, using the following standardized gating strategy. Panel A: gating of mononuclear cells (lymphocytes/monocytes) by their forward/sideward scatter properties. These cells are then gated (Panel B) for CD31+ and CD45- (or low). Sequentially, these cells are then gated for their $\mathrm{KDR}+$ and CD34+ (Panel C). The marker settings for this last panel are determined by the isotype measurement (not shown) in which the population of cells is completely in the lower left quadrant. For putative EPC enumeration, the possible rare events in the upper right quadrant from the isotype measurement are subtracted from the events in the upper right quadrant of panel $\mathrm{C}$.

\section{Counting angiogenic T-cells}

We quantified angiogenic T-cells ( $T_{\text {ang }}$ ) by flow cytometry. We used the monoclonal antibodies PerCP-anti CD3, FITC-anti CD31, and PE-anti CD184 (all from BD Biosciences). We defined $\mathrm{T}_{\text {ang }}$ as $\mathrm{CD}^{+} \mathrm{CD} 31^{+} \mathrm{CD} 184^{+}$(strategy for gating shown in Figure 7.2). We quantified $T_{\text {ang }}$ from peripheral blood as well as from EPC cultures. Cells were harvested from the plates after 7 days culturing.
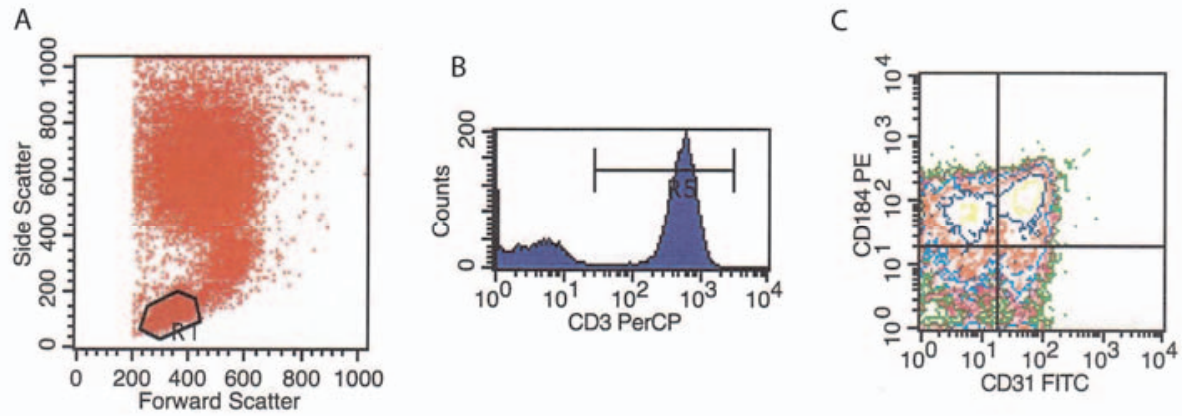

Figure 7.2 Gating strategy used for the flow cytometric enumeration of $T_{\text {ang. }}$. Panel A shows the gating of lymphocytes, based on their forward and side scatter properties. These cells are gated for positivity for CD3 (Panel B), the general T-cell marker. Subsequently, these cells (R5 in panel B) are gated for $C D 31+/ C D 184+$, upper right quadrant of panel $C$, which represents $T_{\text {ang }}$. 


\section{Statistical analysis}

As data were not normally distributed, we evaluated whether significant differences existed between the cellular variables of patients with and without CSVD by means of the Mann-Whitney test. Subsequently, we determined independent predictors for the presence of CSVD using binary logistic regression analyses, with the presence or absence of CSVD as dependent variable and the cellular variables (numbers of T-cells, $\mathrm{T}_{\text {ang }}$ and EPC) as covariates, with correction for blood pressure levels (both systolic and diastolic) and number of antihypertensive drugs, age and sex. All analyses were performed using SPSS version 16.0.

\section{Ethical considerations}

The study was approved by the Medical Ethical Committee of the University Hospital Maastricht and Maastricht University. All patients and controls gave their written informed consent.

\section{Results}

\section{Patient characteristics}

Patient characteristics are shown in Table 7.1, whereas findings on imaging of the study groups are outlined in Table 7.2. As a whole, risk factor profiles were similar between hypertensive patients with and without CSVD. As per definition, patients with CSVD had more extensive WML, more often lacunar infarcts and more often microbleeds.

\section{Table 7.1 Patient characteristics}

\begin{tabular}{|c|c|c|c|}
\hline & $\begin{array}{c}\text { CSVD } \\
(n=32)\end{array}$ & $\begin{array}{c}\text { No CSVD } \\
(n=29)\end{array}$ & p-value \\
\hline Age (mean ( \pm standard deviation (SD))) & $65.2(9.3)$ & $63.0(7.6)$ & 0.306 \\
\hline Male sex (n (\%)) & $18(56.2)$ & $15(51.7)$ & 0.723 \\
\hline Coronary artery disease (n (\%)) & $5(15.6)$ & $4(13.8)$ & 0.840 \\
\hline Peripheral Vascular Disease (n (\%)) & $0(0.0)$ & $0(0.0)$ & \\
\hline Diabetes (n (\%)) & $3(9.4)$ & $1(3.4)$ & 0.350 \\
\hline Current Smoking (n (\%)) & $5(15.6)$ & $2(6.9)$ & 0.339 \\
\hline Systolic Blood Pressure (mmHg; (mean ( $(\mathrm{SD})))$ & $159.5(17.7)$ & $152.8(17.3)$ & 0.144 \\
\hline Diastolic Blood Pressure $(\mathrm{mmHg} ;($ mean $( \pm \mathrm{SD})))$ & $90.8(10.9)$ & $87.2(9.8)$ & 0.177 \\
\hline Duration of hypertension (years; (mean $( \pm S D))$ ) & $12.4(12.9)$ & $14.0(14.9)$ & 0.682 \\
\hline Duration of antihypertensive medication (months; (mean $( \pm S D)$ )) & $93.1(113.8)$ & $97.1(125.3)$ & 0.908 \\
\hline Statin Use (n (\%)) & $13(40.6)$ & $16(55.2)$ & 0.305 \\
\hline ACE inhibitor Use (n (\%)) & $9(28.1)$ & $9(31.0)$ & 1.000 \\
\hline Angiotensin Receptor Blocker Use (n (\%)) & $15(46.9)$ & $16(55.2)$ & 0.671 \\
\hline
\end{tabular}


Table 7.2 Imaging Characteristics of the two patient groups. For the grading of WML, the Fazekas-scale was used. ${ }^{8}$ Periventricular white matter: $0=$ no $\mathrm{WML}, 1=$ caps or pencil thin lining, $2=$ smooth halo, $3=$ extending into deep white matter. Deep white matter: $0=$ no WML, $1=$ punctuate lesions, 2 =beginning confluence of lesions, $3=$ large confluent areas. *chi-square test.

\begin{tabular}{lcccc}
\hline & & $\begin{array}{c}\text { CSVD } \\
(\mathrm{n}=32)\end{array}$ & $\begin{array}{c}\text { No CSVD } \\
(\mathrm{n}=29)\end{array}$ & p-value \\
\hline Asymptomatic Lacunar Infarcts $(\mathrm{n}(\%))$ & $6(18.8)$ & $0(0.0)$ & $<0.001^{*}$ \\
Periventricular White Matter Lesions $(\mathrm{n}(\%))$ & 0 & $1(3.1)$ & $22(75.9)$ & $<0.001^{*}$ \\
& 1 & $15(46.9)$ & $7(24.1)$ & \\
Deep White Matter Lesions (n (\%)) & 2 & $4(12.5)$ & $0(0.0)$ & \\
& 3 & $12(37.5)$ & $0(0.0)$ & \\
& 0 & $4(12.5)$ & $17(58.6)$ & $<0.001^{*}$ \\
Microbleeds $(\mathrm{n}(\%))$ & 1 & $18(56.3)$ & $12(41.4)$ & \\
& 2 & $6(18.8)$ & $0(0.0)$ & \\
& 3 & $4(12.5)$ & $0(0.0)$ & $<0.001^{*}$ \\
\hline
\end{tabular}

\section{Cerebral small vessel disease, EPC, and circulating $T_{\text {ang }}$}

Data for T-cells and putative EPC are shown in Figure 7.3 and the Table 7.3. We found that circulating T-cell numbers were lower in patients with CSVD as compared to those without CSVD. Furthermore, $\mathrm{T}_{\text {ang }}$ numbers as well as EPC numbers were lower in patients with CSVD as compared to those without. However, cluster counts and senescence of the cultured cells were not different between the groups. We performed binary logistic regression analyses to determine significant predictors for the presence of CSVD. After correction for total T-cell counts and blood pressure measurements only higher $\mathrm{T}_{\text {ang }}$ numbers significantly related to the absence of CSVD (OR 0.088; 95\%-Cl 0.012-0.627).

Table 7.3 Cellular variables for patients with and without cerebral small vessel disease. Significant differences indicated by the p-values with *. CSVD is defined as the presence (on MRI of the brain) of one or more of the following: WML, lacunar infarcts or microbleeds.

\begin{tabular}{lccc}
\hline & $\begin{array}{c}\text { CSVD } \\
(\mathrm{n}=32)\end{array}$ & $\begin{array}{c}\text { No CSVD } \\
(\mathrm{n}=29)\end{array}$ & p-value \\
\hline Circulating T-cells $\left(10^{9} / \mathrm{mL}\right.$; median (IQR)) & $1.14(0.53)$ & $1.46(0.54)$ & $0.026^{*}$ \\
Circulating angiogenic T-cells $\left(10^{9} / \mathrm{mL}\right.$; median (IQR)) & $0.56(0.25)$ & $0.78(0.50)$ & $0.008^{*}$ \\
Circulating endothelial progenitor cell concentration & $0.010(0.007)$ & $0.013(0.006)$ & $0.011^{*}$ \\
$\quad\left(10^{6} / \mathrm{mL}\right.$; median (IQR)) & & & \\
ECFC cluster counts (per well; median (IQR)) & $64.5(104.6)$ & $116.3(88.0)$ & 0.129 \\
ECFC telomerase activity (standardized to 100; & $26.0(38.0)$ & $34.0(65.0)$ & 0.492 \\
$\quad$ median (IQR)) & & & 0.445 \\
CFU-EC cluster counts (per well; median (IQR)) & $152.5(81.3)$ & $122.3(63.6)$ & 0.527 \\
$\quad$ CFU-EC telomerase activity (standardized to 100; & $52.5(63.8)$ & $41.0(58.0)$ & \\
$\quad$ median (IQR)) & & & \\
\hline
\end{tabular}



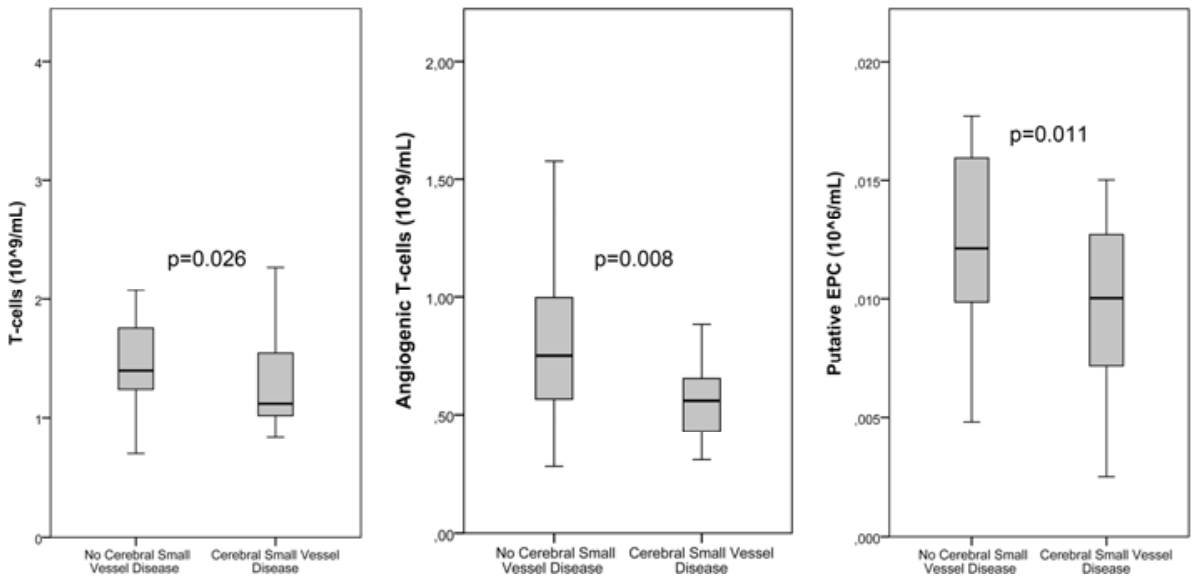

Figure 7.3 Boxplots with median and error bars for counts of T-cells, $T_{\text {ang }}$ and putative EPC. Significances as indicated in the figure.

\section{Discussion}

In the present study, we observed that hypertensive patients with CSVD had lower $\mathrm{T}_{\text {ang }}$ and putative EPC numbers in their blood than hypertensive control patients without CSVD, independently of blood pressure levels. Therefore, we postulate that T-cells, next to EPC, may be involved in the pathogenesis of hypertension related CSVD.

We investigated whether $T_{\text {ang }}$ might be a regulating factor of EPC number and functionality in patients with CSVD. These cells form a subset of T-cells which might play a role in vascular repair, because they stimulate putative EPC in their restorative capacities as evidenced in an in vitro study. ${ }^{5}$ Angiogenic T-cell numbers decrease with age. ${ }^{12}$ We found that numbers of $\mathrm{T}_{\text {ang }}$ were lower in hypertensive patients with CSVD, independent of age. Furthermore, recent studies suggest that T-cells are involved in the pathogenesis of hypertension and in particular in hypertension associated vascular damage. ${ }^{13,14}$ The relation between lower $T_{\text {ang }}$ and CSVD may specifically imply a role of $T_{\text {ang }}$ in CSVD. Still, the nature of this role remains elusive.

Our study has several limitations. First, our study design is cross-sectional and therefore the observed associations could as well be an epiphenomenon of CSVD. Second, the definition of EPC remains controversial, hence the term putative EPC. ${ }^{2}$ However, for both flow cytometry as well as for cultures we used established, authoritative protocols. Third, although variables such as age, sex, and medication did not differ significantly between hypertensive patients with or without CSVD we cannot exclude a mild effect of this difference since age as well as other risk factors inversely relate to EPC and $T_{\text {ang }}$ number. ${ }^{2,5}$ Furthermore, our study contains a relatively small number of patients, which could have led to statistical error. Therefore, future studies 
should be large enough to preclude such shortcoming. Notwithstanding these limitations, the strength of our study remains the novelty of our findings in a well characterized group of hypertensive patients.

\section{Conclusion}

We found that T-cells and putative EPC relate to cerebral small vessel disease in hypertensive patients. In this process, especially angiogenic T-cells may play a role. These findings are novel, and allow novel hypotheses regarding the pathophysiology of CSVD. 


\section{References}

1. Farrall AJ, Wardlaw JM. Blood-brain barrier: ageing and microvascular disease - systematic review and meta-analysis. Neurobiol Aging. 2009;30:337-352

2. Rouhl RPW, van Oostenbrugge RJ, Damoiseaux J, Cohen Tervaert JW, Lodder J. Endothelial progenitor cell research in stroke: a potential shift in pathophysiological and therapeutical concepts. Stroke. 2008;39:2158-2165

3. Hill JM, Zalos G, Halcox JP, Schenke WH, Waclawiw MA, Quyyumi AA, Finkel T. Circulating endothelial progenitor cells, vascular function, and cardiovascular risk. N Engl J Med. 2003;348:593-600

4. Rouhl RPW, van Oostenbrugge RJ, Damoiseaux JGMC, Debrus-Palmans LL, Theunissen ROMFIH, Knottnerus ILH, Staals JEA, Delanghe JR, Tervaert JW, Lodder J. Haptoglobin phenotype may alter endothelial progenitor cell cluster formation in cerebral small vessel disease. Curr Neurovasc Res. 2009;6:32-41

5. Hur J, Yang HM, Yoon CH, Lee CS, Park KW, Kim JH, Kim TY, Kim JY, Kang HJ, Chae IH, Oh BH, Park YB, Kim HS. Identification of a novel role of $T$ cells in postnatal vasculogenesis: characterization of endothelial progenitor cell colonies. Circulation. 2007;116:1671-1682

6. Henskens LH, van Oostenbrugge RJ, Kroon AA, de Leeuw PW, Lodder J. Brain microbleeds are associated with ambulatory blood pressure levels in a hypertensive population. Hypertension. 2008;51:62-68

7. Rouhl RPW, van Oostenbrugge RJ, Knottnerus ILH, Staals JEA, Lodder J. Virchow-Robin spaces relate to cerebral small vessel disease severity. J Neurol. 2008;255:692-696

8. Fazekas F, Chawluk JB, Alavi A, Hurtig HI, Zimmerman RA. MR signal abnormalities at $1.5 \mathrm{~T}$ in Alzheimer's dementia and normal aging. AJR Am J Roentgenol. 1987;149:351-356

9. Werner N, Kosiol S, Schiegl T, Ahlers P, Walenta K, Link A, Bohm M, Nickenig G. Circulating endothelial progenitor cells and cardiovascular outcomes. N Engl J Med. 2005;353:999-1007

10. Duda DG, Cohen KS, Scadden DT, Jain RK. A protocol for phenotypic detection and enumeration of circulating endothelial cells and circulating progenitor cells in human blood. Nat Protoc. 2007;2: 805-810

11. Khan SS, Solomon MA, McCoy JP, Jr. Detection of circulating endothelial cells and endothelial progenitor cells by flow cytometry. Cytometry B Clin Cytom. 2005;64:1-8

12. Kushner EJ, Weil BR, MacEneaney OJ, Morgan RG, Mestek ML, Van Guilder GP, Diehl KJ, Stauffer BL, DeSouza CA. Human aging and CD31+ T-cell number, migration, apoptotic susceptibility, and telomere length. J Appl Physiol. 2010;109:1756-1761

13. Guzik TJ, Hoch NE, Brown KA, McCann LA, Rahman A, Dikalov S, Goronzy J, Weyand C, Harrison DG. Role of the $T$ cell in the genesis of angiotensin II induced hypertension and vascular dysfunction. J Exp Med. 2007;204:2449-2460

14. Cohen Tervaert JW. Hypertension: an autoimmune disease? Hypertens Res. 2011;34:443-444 



\section{Chapter 8}

General discussion

\section{General discussion}




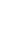

108 Chapter 8 


\section{General discussion}

Cerebral small vessel disease (CSVD) affects the small penetrating arterioles in the brain. CSVD causes lacunar infarcts and white matter lesions (WML). CSVD has a high morbidity as it relates to (recurrent) ischemic stroke, ${ }^{1-3}$ cognitive disturbance and decline, ${ }^{4-12}$ gait disturbances, ${ }^{13}$ and urinary problems. ${ }^{14}$ In lacunar stroke patients, WML relate to a worse prognosis (with regard to morbidity, stroke recurrence, and mortality), ${ }^{1}$ also on the long term, ${ }^{15}$ similar to that of large vessel stroke. ${ }^{15,16}$ However, the cause of lacunar stroke, CSVD, and therefore any therapeutic or preventive regimen, remains elusive. One of the current hypotheses is that blood-brain barrier (BBB) dysfunction will ultimately lead to CSVD. Because the BBB comprises the complex interplay between endothelial cells and the surrounding tissue, dysfunction of one of its components could lead to the dysfunction of the entire BBB. Therefore, the main hypothesis of the research presented in this thesis is that endothelial dysfunction relates to the pathogenesis of CSVD. In this chapter, the main findings of this thesis are presented and put into context. Then, limitations of this thesis' research are discussed. In the last paragraph, implications for future research are discussed.

\section{Main findings and discussion}

\section{Virchow Robin spaces}

In Chapter 2, we demonstrated that higher numbers of enlarged Virchow-Robin spaces (eVRs) at the level of the basal ganglia related to the extent of WML as well as to the presence of asymptomatic lacunar infarcts. Others replicated these findings in different populations: Doubal et al. found that higher eVRs numbers (mainly at basal ganglia level) relate to the lacunar stroke type (as opposed to cortical stroke) and also to WML in stroke patients. ${ }^{17}$ Likewise, Zhu et al. demonstrated in a sample of the general elderly population that the number of eVRs at basal ganglia level related to WML. ${ }^{18}$ Throughout these studies there is a consistent relation between higher numbers of eVRs at basal ganglia level and WML. Although all studies were crosssectional and as such causality cannot be proven, eVRs and WML could have a related origin.

What could be the nature of this common origin? In previous studies and expert opinion papers, VRs enlargement has been attributed to vascular ectasia and tortuosity, increased vessel wall permeability, and to an ex vacuo mechanism from ischemic perivascular tissue loss or cortical atrophy. ${ }^{19-25}$ The latter seems now less likely, because both our study (Chapter 2 ) as well as the study by Zhu et al. ${ }^{18}$ could not demonstrate a relation between a higher number of eVRs and cortical or subcortical atrophy. Thus, the enlargement of the perivascular space seems to be caused by a (pathologic?) structural and/or functional alteration of the penetrating vessel. We 
demonstrated that higher eVRs numbers at basal ganglia level were a significant predictor of higher titers of antibody against oxLDL (Chapter 3 ) as well as of a marker of monocyte activation, neopterin (Chapter 4). We also found that higher eVRs at basal ganglia level related to lower numbers of angiogenic T-cells $\left(T_{\text {ang }}\right)$ as well as of endothelial progenitor cells (EPC) (unpublished data). In both these studies (Chapter 3, 4), the aforementioned plasma constituents also related to WML. Therefore, we postulate that the co-occurrence of eVRs and WML has an underlying biological link, which may be CSVD.

CSVD is probably caused by a disturbed BBB (Chapter 1), which leads to leakage of plasma proteins and fluids into the perivascular space. In the case of the penetrating arterioles, this will be into the Virchow-Robin space, whereas on a capillary level, this will be directly into the brain parenchyma. The fluids in the Virchow-Robin space will then enlarge this previously latent space and appear on brain imaging, especially on MRI. Plasma proteins and fluids are neurotoxic and will induce white matter damage when present in the brain parenchyma, ${ }^{26}$ thus resulting in WML. In this way, increased vessel wall permeability could be the common pathophysiology of both WML as well as eVRs.

Interestingly, the strongest associations we found were between eVRs at basal ganglia level on one hand and periventricular WML as well as asymptomatic lacunar infarcts (mostly in the basal ganglia region) on the other (Chapter 2). Later, others confirmed these findings. ${ }^{17,18}$ This is intriguing, because eVRs and asymptomatic lacunar infarcts occurred in the vascular territory of the penetrating arteriolar branches of the lenticulostriate arteries and periventricular WML in the territory of the medullary arteries, which are branches of the superficial cortical pial arteries. The co-occurrence of eVRs and periventricular WML therefore possibly represents a different susceptibility of these two vascular territories for BBB disruption leading to two different manifestations of the same underlying disease: in the basal ganglia region (eVRs), disruption of the BBB occurs on the arteriolar level, whereas in the periventricular territory (WML), disruption probably occurs more downstream in the capillary bed. Whatever may cause this difference in susceptibility remains elusive, though, a different reaction of the vascular wall to known risk factors like hypertension might play a role. In the basal ganglia region, hypertension may lead to endothelial dysfunction and BBB disruption, with leakage of fluids into the perivascular space leading to eVRs. On the other hand in the periventricular region, hypertension also strongly relates to arteriolosclerosis: a hyaline, concentric wall thickening of the medullary arterioles. Arteriolosclerosis leads to a decreased blood flow, ${ }^{27}$ consequently leading to ischemia, ${ }^{28}$ with resultant BBB dysfunction, possibly mostly downstream in the capillaries, leading to WML.

In conclusion, multiple eVRs suggest an underlying disease in which BBB disruption occurs: CSVD. Therefore, eVRs should not be regarded as a benign phenomenon anymore, and prompt awareness of a possible underlying cause like CSVD. However, 
whether patients with eVRs would benefit of strict risk factor treatment and life style adjustment remains to be elucidated.

\section{Vascular inflammation}

In Chapter 3, we demonstrated that IgM anti-MDA-oxLDL levels were lower, whereas IgG anti-HOCl-oxLDL levels were higher in patients with WML and lacunar infarcts. In Chapter 4 we demonstrated that neopterin levels as well as levels of the soluble adhesion molecules VCAM-1 and ICAM-1 were higher in patients with WML and lacunar infarcts. Importantly, higher eVRs at basal ganglia level independently predicted higher antibody levels to $\mathrm{HOCl}$-oxLDL and neopterin levels.

Adhesion molecules are expressed on the surface of endothelial cells after activation of nuclear factor (NF) KB, whereas NFKB is activated by higher intraluminal (vascular) pressure and shear stress. ${ }^{29,30}$ With progressive endothelial activation, endothelial dysfunction could occur, which leads to shedding of the adhesion molecules into the circulation. Previous studies showed that in the acute phase of stroke, levels of $\mathrm{SE}_{-},{ }^{31-33}$ sP-selectin, ${ }^{31-34}$ sVCAM-1 ${ }^{35}$ and SICAM-1 ${ }^{35,36}$ increase. Higher sICAM-1 levels in the acute stroke phase related to early neurological deterioration and worse outcome at 3 months. ${ }^{37}$ These studies indicate that endothelial dysfunction occurs after stroke. With regard to CSVD, higher SICAM-1 levels relate to $\mathrm{WML}^{38}$ whereas SICAM-1 levels related to progression of WML and lacunar infarcts in community dwellers after 3 or 6 years. ${ }^{39}$ Thus, others found markers of endothelial dysfunction in patients with rather advanced CSVD. We found only a slight, yet significant, difference between extensively affected patients (lacunar infarcts with WML) as compared to patients without CSVD with regard to SICAM-1 and SVCAM-1 levels. This may reflect the abundant use of statins in our study population, as statins are known to lower circulating adhesion molecule levels. ${ }^{40}$ However, the endothelial activation/dysfunction in patients with extensive CSVD could also be modest in itself or be un- or less detectable in the systemic circulation because processes localized to the cerebral small vessels might not lead to a large shift in markers of endothelial dysfunction due to dilution in the systemic circulation. Therefore, we suggest that the, albeit small, difference we found, suggests endothelial dysfunction in CSVD patients.

We could not demonstrate a difference in CRP levels between our patient categories. In contrast, previous studies showed that CRP levels related to age, smoking, obesity, high blood pressure, dyslipidemia, ${ }^{41}$ intima media thickness, ankle-arm blood pressure indexes, $^{42}$ vascular events like myocardial infarction and stroke, ${ }^{43-46}$ and to cerebrovascular events attributable to intracranial arterial stenoses. ${ }^{47}$ Also higher CRP levels after stroke relate to a worse one-year prognosis (regarding disability and mortality). ${ }^{48}$ However, most of these studies are case control studies and probably suffer from selection bias. Indeed, in prospective cohort studies CRP levels do not add value in vascular risk prediction. ${ }^{49,50}$ Similar to the abovementioned situation with the 
levels of circulating adhesion molecules, CRP may not be different between our groups because of our study design (using a cross-sectional cohort study more resembling the latter studies), statin use (statins also lower CRP levels), ${ }^{40}$ confounding factors (which may be concurrent other vascular diseases), and the relatively low contribution of markers of cerebral endothelial dysfunction in the (general) circulation.

Neopterin is a product of activated monocytes/macrophages ${ }^{51}$ and is produced solely as a result of stimulation by interferon-gamma, which, in turn, is produced by T-cells. ${ }^{52}$ Together with other products of activated monocytes/macrophages, neopterin may activate NF-KB in endothelial cells, with increased surface expression of adhesion molecules as a consequence. ${ }^{53}$ In this way, neopterin may lead to a pro-inflammatory phenotype of the endothelial cells, because upon leucocyte adherence to the endothelial cells, both endothelial cells and leukocytes become increasingly activated, ${ }^{54}$ which stimulates mainly the cellular immune response. Clinically, higher neopterin levels related to a higher vascular event rate in a large prospective study of patients with coronary artery disease. ${ }^{55}$ There are no data on neopterin in cerebrovascular diseases. Our study, as described in Chapter 4, suggests that activated monocytes/macrophages are involved in CSVD, though the cause of the activation of monocytes as well as of the endothelial cells remains elusive. In this activation, hypertension might play a role via the stimulation of NF-kB, which stimulates an immune response. However, endothelial activation and CSVD also occur in nonhypertensive subjects. ${ }^{56}$ The possible involvement of (interferon gamma producing) T-cells suggests that one or several specific antigens induce an immune response, in which oxLDL is a candidate antigen, as evidenced by the relations described in Chapter 3.

There are no data, neither experimental nor clinical, on oxLDL in CSVD. Most knowledge on oxLDL and vascular diseases has been gathered in studies on atherosclerosis. In atherosclerosis LDL accumulates in the vessel wall, and is modified from LDL to oxLDL. This oxidation process delivers a whole spectrum of different oxidized LDL particles ${ }^{57}$ which are present in the atherosclerotic plaque. ${ }^{58}$ These oxLDL particles stimulate an inflammatory response, ${ }^{57}$ induce antibodies, ${ }^{59}$ and are phagocytised by macrophages as mediated in particular by IgG anti-oxLDL antibodies. ${ }^{60}$ These macrophages are attracted as monocytes from the circulation by adhesion molecules VCAM-1, ICAM-1, E- and P-selectin, which are expressed on the endothelial cells which line the atherosclerotic plaque. ${ }^{61}$ It is not clear whether the immune response against oxLDL is harmful or beneficial for the development and progression of atherosclerotic lesions. ${ }^{62}$ This may be dependent upon the nature of the T-cell response (a T helper 1 versus a $\mathrm{T}$ helper 2 response). ${ }^{63}$ However, next to a different T-cell response, differential antibody production could also have different consequences: IgG anti-oxLDL antibodies might be harmful in the progression of atherosclerosis, whereas the IgM anti-oxLDL antibodies might be protective. ${ }^{62,64}$ For the measurement of anti-oxLDL antibodies, LDL has to be oxidized in vitro. There are several oxidation methods, amongst which cupper-oxidation and malondialdehyde 
(MDA) modification are the most widely used. Using these techniques to demonstrate anti-oxLDL antibodies, others earlier demonstrated that IgM anti-MDA-oxLDL antibody levels are higher in patients with a thinner intima-media thickness (IMT, a thicker IMT relates to a higher degree of atherosclerosis) in their carotid arteries ${ }^{65}$ and that patients who had IMT progression also had lower IgM anti-MDA-oxLDL antibody levels. ${ }^{66}$ Also, IgM anti-MDA-oxLDL antibodies are lower with increasing degrees of stenosis in coronary artery disease ${ }^{67}$ and in patients with hypertension. ${ }^{68}$ Other diseases in which anti-oxLDL antibodies have been studied are autoimmune diseases typically affecting small vessels: IgG anti-MDA-oxLDL antibodies are elevated in systemic lupus erythomatodes ${ }^{69}$ and in antineutrophil cytoplasmic antibody (ANCA) associated vasculitis. ${ }^{70,71}$

CSVD, however, has a completely different presumed pathogenesis as compared to these auto-immune diseases and atherosclerosis. Though, we found an indication that an auto-immune reaction involving oxLDL relates to CSVD because IgG anti-HOCl-oxLDL antibody levels are higher in CSVD patients, whereas IgM anti-MDA-oxLDL antibodies are lower. This concurs with findings in atherosclerosis in which IgM-isotype antibodies appear beneficial, whereas IgG-isotype antibodies appear harmful. However, how oxLDL could be an antigen causing an immune response in CSVD remains obscure. In pathological studies, no lipid involvement has been described in CSVD, except in microatheromatosis $^{72}$ (which basically is atherosclerosis on a microvascular level). Microatheromatosis relates to somewhat larger lacunar infarcts and is not so strongly related to WML. ${ }^{73}$ Also, hypercholesterolemia is only a weak risk factor for lacunar stroke. ${ }^{74}$ Thus, our findings which indicate an auto-immune process with oxLDL as auto-antigen suggest a previously unsuspected role for lipids as well as for an autoimmune response in simple and complex cerebral small vessel disease (arteriolosclerosis and lipohyalinosis). This might reflect a hypersensitive immune system, similar to several vasculitides, in which mainly T-cells and monocytes are involved. ${ }^{75}$ This hypersensitive immune system might induce endothelial activation and a dysfunctional BBB, resulting in enlargement of VRs. Indeed, we found an independent relation between IgG anti-HOCl-oxLDL antibodies and eVRs and also between neopterin and eVRs, which suggest activation of the humoral (antibody) as well as the cellular (T-cell mediated monocyte activation) immune system. Interestingly, in another neurologic disease, multiple sclerosis, enlargement of the VRs coincides with immune activation. ${ }^{76}$ In line with these findings, our findings might reflect immune activation in CSVD as well.

However, other factors might also explain our results. First, the anti-oxLDL-antibodies may derive from the production in concurrent vascular diseases (like coronary artery disease). Indeed, we did not screen patients for asymptomatic atherosclerosis (conorary and peripheral artery stenosis). However, significant vascular disease would lead to clinical manifestations, which are included in our clinical assessment variables, and after correction in statistical analyses for these variables the relation between anti-oxLDL-antibodies and CSVD remained. Second, the anti-oxLDL-antibodies we 
measured might be antibodies directed to cross-reacting antigens. This is the result of the set-up of our immune-assay: though our oxLDL was over $90 \%$ pure, and coating was well established, other substances might have entered the well in very low concentrations, with possibly resultant antibody binding to these different proteins. The only way to circumvent this is to design another assay, possibly a capture enzymelinked immunesorbent assay (ELISA), in which first an anti-oxLDL antibody is coated to the wells, and then oxLDL is added, before the addition of patient sera. In this way, the only antigen present in the well is oxLDL by its binding to the oxLDL-specific capturing antibodies. Antibody concentrations in the patient sera measured in this way are more specific for oxLDL.

Notwithstanding these limitations, we found significant associations between markers of monocyte activation (cellular immune system) as well as of antibody production (humoral immune system) in two different studies. The fact that these findings are in line with each other might consolidate the association between immune activation in some subtypes of CSVD. Whether this association is a cause or a mere epiphenomenon remains to be established.

\section{Endothelial progenitor cells}

In Chapter 6 we describe that EPC cluster forming potential is lower in lacunar stroke patients with concomitant WML. Furthermore, we found that serum of these patients attenuated cluster formation of EPC of healthy volunteers more than healthy control serum. We demonstrated that the protein haptoglobin, especially in its 1-1 form, could play a role herein. In Chapter 7, we demonstrated that EPC numbers were lower in hypertensive patients with concomitant WML and lacunar infarcts. Furthermore, we found that the number of a subset of T-cells, angiogenic T-cells, were lower in these patients. All these findings suggest that EPC, when present in sufficient number and vitality, might protect from the consequences of CSVD (and WML and lacunar infarcts in particular).

The presumed protective nature of EPC in vascular diseases derives from the fact that EPC offspring is present in previously damaged and restored endothelium ${ }^{77-80}$ and that EPC numbers are lower in patients with atherosclerotic risk factors, ${ }^{81}$ such as hypertension, ${ }^{82-85}$ and patients at increased risk of vascular events. ${ }^{81,86,87}$ In these patients, EPC numbers probably are lower as a consequence of a higher consumption, and run relatively short on restoring the damaged endothelium possibly resulting in cardiovascular events. Like we already pointed out, neurovascular research on EPC remains limited. At present it is only known that EPC levels rise after stroke, ${ }^{88,89}$ though stroke patients still have lower EPC levels than healthy controls, ${ }^{87,90}$ and that a higher EPC number or increase in EPC in the first week relates to a better outcome. ${ }^{91}$ In the only published study in which different stroke pathophysiologies were distinguished, EPC numbers were higher in patients with cardioembolic stroke than in patients with large or small vessel stroke. ${ }^{90}$ The mechanism which underlies EPC recruitment in 
stroke includes probably the release of angiogenic factors, like VEGF and SDF-1 $\alpha^{92,93}$ triggered by the ischemic tissue. The recruitment of EPC will lead to homing of EPC to the endothelium of the damaged blood vessels, amongst others regulated by SDF-1 $\alpha$ and its receptor, CXCR4 or CD184. ${ }^{94}$ From experimental animal stroke models, however, we know that despite an increase of the formation of new blood vessels ${ }^{95}$ and blood flow $^{96}$ after EPC administration performed after the stroke, few transplanted cells are actually found in the brain vasculature and its surroundings, ${ }^{97}$ and these cells are only infrequently of endothelial phenotype. ${ }^{98}$ Therefore, $^{\circ}$ mechanisms of action of EPC probably rely on the secretion of angiogenic factors which induce endothelial regeneration and formation of new blood vessels. Furthermore, the beneficial effects of EPC in the brain are probably not limited to neovascularization but also may relate to neurogenesis, which occurs after stroke from neural progenitor cells present in the brain, ${ }^{99}$ and also to migration of these neural progenitor cells along the newly formed vessels. ${ }^{100}$ These processes are tightly linked, as also evidenced by in vitro studies: soluble factors produced by endothelial cells regulate proliferation of neuronal progenitor cells and cell-cell contact between the two cell types regulates their differentiation. ${ }^{101}$ Important mediators in this process are VEGF and SDF-1. ${ }^{102}$ Therefore, possibly other cells with the SDF-1 $\alpha$ receptor also play a role. This is suggested by Hur et al. in their study concerning angiogenic T-cells (phenotypically defined as CD3+/CD31+/CD184+). ${ }^{103}$ These angiogenic T-cells form the center of EPC clusters in in vitro cultures, stimulate differentiation of EPC, secrete angiogenic factors (VEGF, IL-8, MMPs), and react on angiogenic signaling. Thus, presuming that EPC as well as angiogenic T-cells both paracrinely stimulate endothelial repair and new vessel formation, their lower numbers in hypertensive patients with CSVD and a lower function of EPC in patients with lacunar stroke and concomitant WML might reflect a (partially) dysfunctional endothelial repair response, which is due to a decreased paracrine stimulation potential of the EPC and angiogenic T-cells.

However, are these cells likely to be involved in CSVD pathogenesis? In regions of the brain with WML, the receptor for hypoxia inducible factor, is upregulated. ${ }^{28}$ This receptor is a signal post for ischemia and it induces the production of the angiogenic cytokine SDF-1. ${ }^{104}$ Cells with a SDF-1 receptor (CXCR4) will then adhere to these regions. ${ }^{104}$ Amongst these cells are angiogenic T-cells ${ }^{103}$ and EPC. This suggests that EPC and angiogenic T-cells only enter the arena in a more advanced stage, after ischemia has occurred. It is also unclear whether the EPC and angiogenic T-cells induce a normal healing process (formation of new vessels, sprouting and a decrease in ischemia) or a more or less pathologic alteration of the vessel wall (disturbance of the normal BBB, because neoangiogenesis may produce leaky vessels). Nevertheless, a decreased EPC function may as well be involved in an earlier stage. We found that a specific phenotype of the acute phase protein haptoglobin, the 1-1 phenotype, relates to WML and asymptomatic lacunar infarcts, ${ }^{105,106}$ whereas we demonstrated in Chapter 6 that haptoglobin 1-1 relates to a lower EPC function, also in vitro. Mostly, this effect is ascribed to the angiogenic properties of its counterpart, the haptoglobin 
2-2, whereas haptoglobin 1-1 has more potent anti-oxidant properties. ${ }^{107}$ Indeed, when EPC with a haptoglobin 2-2 gene were given to mice with hind limb ischemia, more limbs were saved than with EPC with haptoglobin 1-1 genes, again probably via paracrine stimulation of the formation of new vessels. ${ }^{108}$ The EPC with haptoglobin 2-2 genes mostly had a better differentiation potential whereas their proliferation capacity was similar to the 1-1 haplotype. ${ }^{108}$ Because the determinant for the haptoglobin phenotype is the genetic makeup, we suggest that these effects on EPC and angiogenesis are of long duration and may influence the development of CSVD.

Are EPC numbers or function likely to be regulated by genetic factors? A lower EPC number could be genetically determined, as EPC numbers strongly correlate between CAD patients and their sibs. ${ }^{109}$ Another genetic factor which may influence EPC is the SDF-1 gene. Recently, it was demonstrated that EPC cluster counts relate to SDF-1 $\alpha$ blood levels, and furthermore, that a single nucleotide polymorphism in the SDF-1 gene (AA at rs2297630) relates to increased SDF-1 $\alpha$ levels and lower EPC cluster counts. ${ }^{110}$

We also demonstrated that factors present in serum of CSVD patients can attenuate EPC cluster formation. It is not likely that in these patient sera, only different phenotypes of haptoglobin and different concentrations of SDF-1 $\alpha$ account for the attenuation we found. Other (partially) genetically determined factors, like homocystein (hyperhomocysteinemia), cholesterol (hypercholesterolemia), and glucose (diabetes mellitus) may also have contributed, whereas also other factors, related to acquired diseases and risk factors (like nicotin from smoking, use of medications like statins, ACE-inhibitors or aspirin) may also relate somewhat to the EPC functional characteristics, like we discussed in Chapter 5. We could not find any influence of these parameters on EPC number or cluster counts, probably because our study was underpowered to detect such influence. Therefore, we cannot exclude a minor contribution of these serum factors on EPC outgrowth. However, next to these factors, there are some other candidates, like vitamin B12 (hydroxocobalamin). Earlier, we demonstrated that lower vitamin B12 levels, especially below $200 \mathrm{pmol} / \mathrm{mL}$, relate to WML. ${ }^{111}$ Furthermore, vitamin B12 is presumed to have a role in maintaining the integrity of the BBB, as evidenced in animal and human studies. ${ }^{112,113}$ We also demonstrated that lower vitamin B12 levels relate to lower EPC cluster formation. ${ }^{114,115}$ Whether the beneficial effects of vitamin B12 for BBB integrity are exerted by its influence on EPC remains to be elucidated.

In conclusion, EPC research holds great promise, as the presumed endothelial dysfunction, which probably precedes BBB dysfunction in CSVD, could be causally related to EPC disturbance, whether in number or function. Possible therapeutical interventions by EPC stimulating drugs could be subject of further study. ${ }^{116}$

\section{Limitations of the current studies}

In order to place the results of our studies in context, several shortcomings as well as limitations with regard to applicability of our results have to be borne in mind. Some 
apply to all our studies, as presented in this thesis. Of these limitations, the first is the cross-sectional design of the studies: therefore, all relations we found are associations which may, or may not, be causal. When only using a cross-sectional design, it remains impossible to distinguish a mere association from a direct, causal relation. Probably, only longitudinal follow up studies may overcome this problem. The second limitation is that we only indirectly studied one of the components of the BBB, the endothelial cells. We only studied endothelial cell activation/dysfunction and presumed endothelial repair mechanisms, whilst disregarding other components of the BBB (pericytes, astrocytes and extracellular matrix). These other cells involved in the BBB could also play a role in the development of hypoxia. For example, pericytes contract around blood vessels in ischemic zones even after restoration of flow. ${ }^{117}$ However, secluded as they are in the brain, these components do not allow a direct study in humans. Only animal studies may overcome this problem, though there is no (perfect) animal model for cerebral small vessel disease. Somewhat in line with the second limitation is the third: we only partially studied the vascular inflammation and endothelial repair responses, and therefore mechanisms leading to an inflammatory response or a defective endothelial repair remain elusive. Nevertheless, our findings provide a start for future studies regarding these mechanisms. The fourth limitation is that we studied markers in peripheral blood and not in the brain itself. Therefore, confounding factors like other vascular diseases, or a systemic small vessel disease could also account for the differences we found, though we corrected wherever possible for these conditions. The fifth limitation concerns the MR protocol and assessments. We did not use diffusion weighted imaging (DWI) nor T1 imaging; though, probably, in the chronic stage of CSVD in which we scanned our study participants, using DWI is not of additional value and could even overlook lacunar infarcts. ${ }^{118}$ Cavitation is as well visualized by FLAIR as by T1. Concerning the assessment procotols, we did not use standardized scales for detection of Virchow Robin spaces, like the recently proposed protocol by Wardlaw et al., or for brain microbleeds (Brain Observer MicroBleed Scale, BOMBS ${ }^{119}$ ). This only affects direct comparability of our studies with others regarding these assessment parameters, and not the (internal) validity of our data. The last limitation is that we studied two different patient cohorts conjointly, hypertensive patients and lacunar stroke patients, which leads to the assumption that in these patient cohorts the pathogenesis of the CSVD related abnormalities is similar. Probably, the pathophysiology is the same in these two patients groups, as blood pressure relates to the development of WML, ${ }^{120}$ silent infarcts, ${ }^{121,122}$, and microbleeds. ${ }^{123,124}$ However, CSVD also occurs in the absence of hypertension. Thus, hypertensive patients and lacunar stroke patients might not have a similar pathophysiology of their MR abnormalities. When rejecting the assumption of similarity, and analysing the patient groups separately, our studies lose statistical power due to smaller patient groups. This is mainly reflected by our findings in Chapters 3 and 4, in which several markers differed significantly between patients with and without CSVD. However, when lacunar stroke patient data and hypertensive 
patient data were analyzed separately, the relations were weaker or even absent. Though, directions of associations did not change, which substantiates similarity between the two groups.

\section{Future directions for research}

The studies presented in this thesis all suggest that the (cerebral) endothelium is involved in a process with inflammation and defective endothelial repair. This process might lead to a dysfunction of the BBB and CSVD.

However, several questions remain:

1) Do markers of endothelial activation (adhesion molecules) and inflammation (neopterin), enlarged Virchow-Robin spaces, and cellular parameters (EPC numbers and vitality as well as angiogenic T-cells) also predict the progression of CSVD related abnormalities on MRI and the development of clinical manifestations like cognitive disturbance?

2) Are the parameters we measured really reflecting endothelial activation/ dysfunction and/or damage and does this process really occur in the brain?

3) Is enhancement of the endothelial repair mechanism possible and does this enhancement lead to improvement or attenuation of CSVD?

\section{Do endothelial and inflammatory parameters predict CSVD progression?}

A follow up study in the same patient population would change the study design into a (longitudinal) cohort study, which allows predictive assessments. In such a study, the data presented in this thesis would serve as baseline data, and follow-up data should be collected at least 2 years after the initial data collection. Follow-up should at least consist of MRI imaging of the brain to look for progression of the MRI characteristics of CSVD $^{125}$ (mainly WML, lacunar infarcts and microbleeds). Furthermore, the clinically related features like cognitive function may also be tested at follow-up. Baseline data concerning the biological parameters in peripheral blood could then be related to CSVD progression and cognitive function over time. Hypotheses of these studies would include that higher levels of adhesion molecules (like sVCAM-1, sICAM-1, sE-selectin), neopterin, IgG anti-oxLDL antibodies and eVRs at basal ganglia levels, and lower levels of IgM anti-oxLDL antibodies, EPC numbers and vitality, and angiogenic T-cells relate to CSVD progression on MRI as well as to a lesser cognitive performance status at follow up. Whether these parameters specifically relate to progression on different aspects of CVSD (white matter lesions, lacunar infarcts, microbleeds, or enlargement of VirchowRobin spaces) might then also be tested. 


\section{Is the endothelial activation real? Does it really occur in the brain?}

Are we really measuring endothelial activation and damage when we use circulating levels of soluble adhesion molecules? This question will remain unresolved, because also other cells (like smooth muscle cells and leukocytes) produce soluble adhesion molecules which can be demonstrated in peripheral blood. Though the soluble adhesion molecules in peripheral blood are indicative of endothelial activation and dysfunction, they do not prove it. Other markers which indicate endothelial damage are circulating (mature) endothelial cells, which have been shed into the circulation. However, this already is a result of damage and not purely activation/dysfunction. A more laborious parameter is the endothelial microparticle (EMP). EMPs are small vesicles which are released by endothelial cells upon activation. EMPs mainly express endothelial activation markers, like E-selectin (CD62E), ICAM-1 (CD54) and VCAM $(C D 106)^{126}$. EMP might provide a more reliable marker for endothelial activation (without obligatory endothelial dysfunction or damage) than circulating mature endothelial cells or adhesion molecules. Though, assessment of EMPs is difficult and non-stadardized.

Additionally, more mechanistic studies will have to be designed to demonstrate endothelial involvement as well as inflammatory activity in CSVD. Current imaging techniques are insufficient to visualize this microscopic vascular pathology in a lacunar stroke and/or WML patient. MRI only provides an indirect image of the pathological process. Molecular imaging might add new insight. It could advance knowledge on pathogenesis by direct visualization of endothelial activation, using probes targeted to endothelial cell adhesion molecules.In such a way, e-Selectin ${ }^{127,128-130}$ has been demonstrated in vivo in the brain of rodents. Similarly, VCAM espression ${ }^{131-133}$ and Pselectin $^{132}$ expression can be visualised. These markers of endothelial activation and dysfunction, as have been demonstrated in WML patients in peripheral blood can be imaged in vivo in animal models of different diseases. In patients with WML and lacunar infarcts, the demonstration of endothelial activation in the arterioles in the basal ganglia region and the deep white matter (in diseased areas, but especially in non-diseased areas, as demonstrated with regular MRI) would substantiate the hypothesis that endothelial activation/dysfunction may be involved in the pathogenesis of CSVD.

Other imaging modalities, like MR-spectroscopy ${ }^{134}$ PET-CT imaging using FDG, ${ }^{135}$ and 7 Tesla MR imaging in itself, could also contribute to our understanding of the pathology which underlies WML. However, all three of these modalities only provide indirect data because they depend on secondary changes in function of the endothelial cells or on neuronal damage. Though, 7 Tesla Imaging could be useful for assessing the presence of microatheromatosis, because the vessels in which microatheromatosis is localized (diameter of around 300 micrometers) can be visualized with 7 Tesla imaging. ${ }^{136}$ 


\section{Enhancement of the endothelial repair, does it attenuate CSVD progression?}

Endothelial repair mechanisms could attenuate the vascular inflammation with resultant endothelial activation/dysfunction. By improving EPC function endothelial activation/dysfunction might be reversed. For this improvement there are several candidate substances. The first is vitamin B12. Vitamin B12 is presumed to have a role in maintaining the integrity of the BBB, as evidenced in animal and human studies, ${ }^{112,113}$ and we demonstrated that lower vitamin B12 levels relate to lower EPC cluster formation. ${ }^{114,115}$ Supplementation of vitamin B12 might lead to higher EPC vitality and possibly to the attentuation of CSVD progression. To demonstrate this effect a pilot study in lacunar stroke patients with vitamin B12 levels below 200 pmol/L is warranted.

Next to vitamin B12, another vitamin, vitamin D, may also have a beneficial effect. In acute stroke vitamin D levels (25-dihydroxy-vitamin D) are lower, corrected for the seasonal variation, as compared to normal values. ${ }^{137}$ Furthermore, two recent studies demonstrated that lower vitamin D levels related to lower EPC numbers ${ }^{138,139}$ as well as to an impaired endothelial function as measured by a flow-mediated brachial artery dilatation test in patients with vascular diseases. ${ }^{139}$ So, next to its actions on calcium and bone homeostasis, vitamin D may influence endothelial function. Furthermore, vitamin $\mathrm{D}$ also appears to be an immunomodulator, at least in autoimmune diseases like multiple sclerosis. ${ }^{140}$ Vitamin $D$ performs the immunomodulatory action probably via the induction or activation of regulatory T-cells. These are cells which maintain immune tolerance and regulate (mostly dampen) immune responses. Given these effects, they could also exert their immunomodulatory function in other diseases in which the immune system is involved. Indeed, in a recent experimental study in mice prone to develop atherosclerosis, vitamin D supplementation led to the inhibition of plaque formation, probably by the induction of regulatory T-cells. ${ }^{141}$ Now, could these processes also play a role in CSVD? From our preliminary data, I suggest that this link is possible and deserves attention, because we found that regulatory T-cell numbers independently related to angiogenic T-cell numbers (unpublished data). Supplementation of vitamin D may, by inducing regulatory T-cells indirectly influence angiogenic T-cells and possibly EPC leading to a better endothelial function, lesser BBB leakage and attenuation of CSVD. However, this relation is speculative. All these steps will need further study to elucidate a possible role for vitamin $D$ in the treatment and prevention of CSVD.

\section{General conclusions}

The studies presented in this thesis mainly provide the starting point of further study, without clinical implication at this time. Future research could be directed at the 
involvement of the immune system (activated monocytes/macrophages, antibody producing cells, as well as (angiogenic) T-cells) and endothelial dysfunction in the development of CSVD. Also, the role of endothelial progenitor cells and the immune system in the (attenuation of) CSVD progression could be an important line for further research. Especially, the role of vitamin suppletion (vitamin B12 and possibly vitamin D) as new therapies to enhance EPC and BBB function deserves attention.

Thus, cerebral small vessel disease no longer appears a degenerative, non-modifiable disease. 


\section{References}

1. de Jong G, Kessels F, Lodder J. Two types of lacunar infarcts: further arguments from a study on prognosis. Stroke. 2002;33:2072-2076

2. Vermeer SE, Hollander M, van Dijk EJ, Hofman A, Koudstaal PJ, Breteler MM. Silent brain infarcts and white matter lesions increase stroke risk in the general population: the Rotterdam Scan Study. Stroke. 2003;34:1126-1129

3. Kuller LH, Longstreth WT, Jr., Arnold AM, Bernick C, Bryan RN, Beauchamp NJ, Jr. White matter hyperintensity on cranial magnetic resonance imaging: a predictor of stroke. Stroke. 2004;35: 1821-1825

4. Prins ND, van Dijk EJ, den Heijer T, Vermeer SE, Koudstaal PJ, Oudkerk M, Hofman A, Breteler MM. Cerebral white matter lesions and the risk of dementia. Arch Neurol. 2004;61:1531-1534

5. Reed BR, Eberling JL, Mungas D, Weiner M, Kramer JH, Jagust WJ. Effects of white matter lesions and lacunes on cortical function. Arch Neurol. 2004;61:1545-1550

6. Wen HM, Mok VC, Fan YH, Lam WW, Tang WK, Wong A, Huang RX, Wong KS. Effect of white matter changes on cognitive impairment in patients with lacunar infarcts. Stroke. 2004;35:1826-1830

7. Tullberg M, Fletcher E, DeCarli C, Mungas D, Reed BR, Harvey DJ, Weiner MW, Chui HC, Jagust WJ. White matter lesions impair frontal lobe function regardless of their location. Neurology. 2004;63: 246-253

8. Carey CL, Kramer JH, Josephson SA, Mungas D, Reed BR, Schuff N, Weiner MW, Chui HC. Subcortical lacunes are associated with executive dysfunction in cognitively normal elderly. Stroke. 2008;39: 397-402

9. Prins ND, van Dijk EJ, den Heijer T, Vermeer SE, Jolles J, Koudstaal PJ, Hofman A, Breteler MM. Cerebral small-vessel disease and decline in information processing speed, executive function and memory. Brain. 2005;128:2034-2041

10. Wright CB, Festa JR, Paik MC, Schmiedigen A, Brown TR, Yoshita M, DeCarli C, Sacco R, Stern Y. White matter hyperintensities and subclinical infarction: associations with psychomotor speed and cognitive flexibility. Stroke. 2008;39:800-805

11. Garde E, Lykke Mortensen E, Rostrup E, Paulson OB. Decline in intelligence is associated with progression in white matter hyperintensity volume. J Neurol Neurosurg Psychiatry. 2005;76:1289-1291

12. van Dijk EJ, Prins ND, Vrooman HA, Hofman A, Koudstaal PJ, Breteler MM. Progression of cerebral small vessel disease in relation to risk factors and cognitive consequences: Rotterdam Scan study. Stroke. 2008;39:2712-2719

13. Baezner H, Blahak C, Poggesi A, Pantoni L, Inzitari D, Chabriat H, Erkinjuntti T, Fazekas F, Ferro JM, Langhorne P, O'Brien J, Scheltens P, Visser MC, Wahlund LO, Waldemar G, Wallin A, Hennerici MG. Association of gait and balance disorders with age-related white matter changes: the LADIS study. Neurology. 2008;70:935-942

14. Poggesi A, Pracucci G, Chabriat H, Erkinjuntti T, Fazekas F, Verdelho A, Hennerici M, Langhorne $P$, O'Brien J, Scheltens P, Visser MC, Crisby M, Waldemar G, Wallin A, Inzitari D, Pantoni L. Urinary Complaints in Nondisabled Elderly People with Age-Related White Matter Changes: The Leukoaraiosis And DISability (LADIS) Study. J Am Geriatr Soc. 2008;56:1638-1643

15. Staals J, van Raak L, Hilton A, Lodder J. Differences in Long-Term Survival in Two Lacunar Stroke Types: A 15-Year Follow-Up Study in 782 Cerebral Infarct Patients. Cerebrovasc Dis. 2007;25:26-31

16. Sacco S, Marini C, Totaro R, Russo T, Cerone D, Carolei A. A population-based study of the incidence and prognosis of lacunar stroke. Neurology. 2006;66:1335-1338

17. Doubal FN, Maclullich AM, Ferguson KJ, Dennis MS, Wardlaw JM. Enlarged Perivascular Spaces on MRI Are a Feature of Cerebral Small Vessel Disease. Stroke. 2010;41:450-454

18. Zhu YC, Tzourio C, Soumare A, Mazoyer B, Dufouil C, Chabriat H. Severity of dilated Virchow-Robin spaces is associated with age, blood pressure, and MRI markers of small vessel disease: a populationbased study. Stroke. 2010;41:2483-2490

19. Ball MJ. "Leukoaraiosis" explained. Lancet. 1989;1:612-613

20. Barkhof F. Enlarged Virchow-Robin spaces: do they matter? I Neurol Neurosurg Psychiatry. 2004; $75: 1516-1517$ 
21. Hiroki M, Miyashita K, Oda M. Tortuosity of the white matter medullary arterioles is related to the severity of hypertension. Cerebrovasc Dis. 2002;13:242-250

22. Hughes W. Origin of lacunes. Lancet. 1965:19-21

23. Nonaka H, Akima M, Hatori T, Nagayama T, Zhang Z, Ihara F. The microvasculature of the cerebral white matter: arteries of the subcortical white matter. J Neuropathol Exp Neurol. 2003;62:154-161

24. Pico F, Labreuche J, Touboul PJ, Leys D, Amarenco P. Intracranial arterial dolichoectasia and smallvessel disease in stroke patients. Ann Neurol. 2005;57:472-479

25. Suzuki K, Masawa N, Takatama M. Pathogenesis of état criblé in experimental hypertensive rats. Journal of Stroke and Cerebrovascular Diseases. 2001;10:106-112

26. Wardlaw JM, Sandercock PA, Dennis MS, Starr J. Is breakdown of the blood-brain barrier responsible for lacunar stroke, leukoaraiosis, and dementia? Stroke. 2003;34:806-812

27. Huynh TJ, Murphy B, Pettersen JA, Tu H, Sahlas DJ, Zhang L, Symons SP, Black S, Lee TY, Aviv RI. CT perfusion quantification of small-vessel ischemic severity. AJNR Am J Neuroradiol. 2008;29:1831-1836

28. Fernando MS, Simpson JE, Matthews F, Brayne C, Lewis CE, Barber R, Kalaria RN, Forster G, Esteves F, Wharton SB, Shaw PJ, O'Brien JT, Ince PG. White matter lesions in an unselected cohort of the elderly: molecular pathology suggests origin from chronic hypoperfusion injury. Stroke. 2006;37:1391-1398

29. Lemarié CA, Esposito B, Tedgui A, Lehoux S. Pressure-induced vascular activation of nuclear factorkappaB: role in cell survival. Circ Res. 2003;93:207-212

30. Resnick N, Yahav H, Shay-Salit A, Shushy M, Schubert S, Zilberman LC, Wofovitz E. Fluid shear stress and the vascular endothelium: for better and for worse. Prog Biophys Mol Biol. 2003;81:177-199

31. Frijns CJ, Kappelle U, van Gijn J, Nieuwenhuis HK, Sixma JJ, Fijnheer R. Soluble adhesion molecules reflect endothelial cell activation in ischemic stroke and in carotid atherosclerosis. Stroke. 1997;28:2214-2218

32. Kozuka K, Kohriyama T, Nomura E, Ikeda J, Kajikawa H, Nakamura S. Endothelial markers and adhesion molecules in acute ischemic stroke--sequential change and differences in stroke subtype. Atherosclerosis. 2002;161:161-168

33. Cherian P, Hankey GJ, Eikelboom JW, Thom J, Baker RI, McQuillan A, Staton J, Yi Q. Endothelial and platelet activation in acute ischemic stroke and its etiological subtypes. Stroke. 2003;34:2132-2137

34. Tsai NW, Chang WN, Shaw CF, Jan CR, Chang HW, Huang CR, Chen SD, Chuang YC, Lee LH, Wang HC, Lee $\mathrm{TH}$, Lu CH. Levels and value of platelet activation markers in different subtypes of acute noncardio-embolic ischemic stroke. Thromb Res. 2009;124:213-218

35. Blann A, Kumar P, Krupinski J, McCollum C, Beevers DG, Lip GY. Soluble intercellular adhesion molecule-1, E-selectin, vascular cell adhesion molecule-1 and von Willebrand factor in stroke. Blood Coagul Fibrinolysis. 1999;10:277-284

36. Sánchez-Moreno C, Dashe JF, Scott T, Thaler D, Folstein MF, Martin A. Decreased levels of plasma vitamin $C$ and increased concentrations of inflammatory and oxidative stress markers after stroke. Stroke. 2004;35:163-168

37. Castellanos M, Castillo J, Garcia MM, Leira R, Serena J, Chamorro A, Davalos A. Inflammation-mediated damage in progressing lacunar infarctions: a potential therapeutic target. Stroke. 2002;33:982-987

38. Han JH, Wong KS, Wang YY, Fu JH, Ding D, Hong Z. Plasma level of sICAM-1 is associated with the extent of white matter lesion among asymptomatic elderly subjects. Clin Neurol Neurosurg. 2009;111:847-851

39. Markus HS, Hunt B, Palmer K, Enzinger C, Schmidt H, Schmidt R. Markers of endothelial and hemostatic activation and progression of cerebral white matter hyperintensities: longitudinal results of the Austrian Stroke Prevention Study. Stroke. 2005;36:1410-1414

40. van Haelst PL, van Doormaal JJ, May JF, Gans RO, Crijns HJ, Cohen Tervaert JW. Secondary prevention with fluvastatin decreases levels of adhesion molecules, neopterin and C-reactive protein. Eur J Intern Med. 2001;12:503-509

41. Saito M, Ishimitsu T, Minami J, Ono H, Ohrui M, Matsuoka H. Relations of plasma high-sensitivity Creactive protein to traditional cardiovascular risk factors. Atherosclerosis. 2003;167:73-79

42. van der Meer IM, de Maat MP, Bots ML, Breteler MM, Meijer J, Kiliaan AJ, Hofman A, Witteman JC. Inflammatory mediators and cell adhesion molecules as indicators of severity of atherosclerosis: the Rotterdam Study. Arterioscler Thromb Vasc Biol. 2002;22:838-842

43. Ridker PM, Cushman M, Stampfer MJ, Tracy RP, Hennekens CH. Inflammation, aspirin, and the risk of cardiovascular disease in apparently healthy men. N Engl J Med. 1997;336:973-979 
44. Ridker PM, Hennekens $\mathrm{CH}$, Buring JE, Rifai N. C-reactive protein and other markers of inflammation in the prediction of cardiovascular disease in women. N Engl J Med. 2000;342:836-843

45. Rost NS, Wolf PA, Kase CS, Kelly-Hayes M, Silbershatz H, Massaro JM, D'Agostino RB, Franzblau C, Wilson PW. Plasma concentration of C-reactive protein and risk of ischemic stroke and transient ischemic attack: the Framingham study. Stroke. 2001;32:2575-2579

46. Wakugawa Y, Kiyohara Y, Tanizaki Y, Kubo M, Ninomiya T, Hata J, Doi Y, Okubo K, Oishi Y, Shikata K, Yonemoto K, Maebuchi D, Ibayashi S, lida M. C-reactive protein and risk of first-ever ischemic and hemorrhagic stroke in a general Japanese population: the Hisayama Study. Stroke. 2006;37:27-32

47. Arenillas JF, Alvarez-Sabin J, Molina CA, Chacon P, Montaner J, Rovira A, Ibarra B, Quintana M. Creactive protein predicts further ischemic events in first-ever transient ischemic attack or stroke patients with intracranial large-artery occlusive disease. Stroke. 2003;34:2463-2468

48. Di Napoli M, Papa F, Bocola V. C-reactive protein in ischemic stroke: an independent prognostic factor. Stroke. 2001;32:917-924

49. Danesh J, Wheeler JG, Hirschfield GM, Eda S, Eiriksdottir G, Rumley A, Lowe GD, Pepys MB, Gudnason V. C-reactive protein and other circulating markers of inflammation in the prediction of coronary heart disease. N Engl J Med. 2004;350:1387-1397

50. van der Meer IM, de Maat MP, Kiliaan AJ, van der Kuip DA, Hofman A, Witteman JC. The value of Creactive protein in cardiovascular risk prediction: the Rotterdam Study. Arch Intern Med. 2003;163: 1323-1328

51. Hoffmann G. More on: neopterin induces the proatherothrombotic phenotype in human coronary endothelial cells. J Thromb Haemost. 2007;5:211-212

52. Schroecksnadel K, Frick B, Winkler C, Fuchs D. Crucial role of interferon-gamma and stimulated macrophages in cardiovascular disease. Curr Vasc Pharmacol. 2006;4:205-213

53. Cirillo P, Pacileo M, S DER, Calabro P, Gargiulo A, Angri V, Granato-Corigliano F, Fiorentino I, Prevete N, R DEP, Mauro C, Leonardi A, Chiariello M. Neopterin induces pro-atherothrombotic phenotype in human coronary endothelial cells. J Thromb Haemost. 2006;4:2248-2255

54. Schubert SY, Benarroch A, Monter-Solans J, Edelman ER. Monocyte activation state regulates monocyte-induced endothelial proliferation through Met signaling. Blood. 2010;115:3407-2412

55. Ray KK, Morrow DA, Sabatine MS, Shui A, Rifai N, Cannon CP, Braunwald E. Long-term prognostic value of neopterin: a novel marker of monocyte activation in patients with acute coronary syndrome. Circulation. 2007;115:3071-3078

56. Lammie GA, Brannan F, Slattery J, Warlow C. Nonhypertensive cerebral small-vessel disease. An autopsy study. Stroke. 1997;28:2222-2229

57. Steinberg D. Lewis A. Conner Memorial Lecture. Oxidative modification of LDL and atherogenesis. Circulation. 1997;95:1062-1071

58. Ylä-Herttuala S, Palinski W, Rosenfeld ME, Parthasarathy S, Carew TE, Butler S, Witztum JL, Steinberg D. Evidence for the presence of oxidatively modified low density lipoprotein in atherosclerotic lesions of rabbit and man. J Clin Invest. 1989;84:1086-1095

59. Palinski W, Rosenfeld ME, Yla-Herttuala S, Gurtner GC, Socher SS, Butler SW, Parthasarathy S, Carew TE, Steinberg D, Witztum JL. Low density lipoprotein undergoes oxidative modification in vivo. Proc Natl Acad Sci U S A. 1989;86:1372-1376

60. Wu R, Lefvert AK. Autoantibodies against oxidized low density lipoproteins (oxLDL): characterization of antibody isotype, subclass, affinity and effect on the macrophage uptake of oxLDL. Clin Exp Immunol. 1995;102:174-180

61. Glass CK, Witztum JL. Atherosclerosis. the road ahead. Cell. 2001;104:503-516

62. Shoenfeld Y, Wu R, Dearing LD, Matsuura E. Are anti-oxidized low-density lipoprotein antibodies pathogenic or protective? Circulation. 2004;110:2552-2558

63. Hansson GK. Vaccination against atherosclerosis: science or fiction? Circulation. 2002;106:1599-1601

64. Matsuura E, Kobayashi K, Tabuchi M, Lopez LR. Oxidative modification of low-density lipoprotein and immune regulation of atherosclerosis. Prog Lipid Res. 2006;45:466-486

65. Karvonen J, Päivänsalo M, Kesäniemi YA, Hörkkö S. Immunoglobulin M type of autoantibodies to oxidized low-density lipoprotein has an inverse relation to carotid artery atherosclerosis. Circulation. 2003;108:2107-2112 
66. Su J, Georgiades A, Wu R, Thulin T, de Faire U, Frostegard J. Antibodies of IgM subclass to phosphorylcholine and oxidized LDL are protective factors for atherosclerosis in patients with hypertension. Atherosclerosis. 2006;188:160-166

67. Tsimikas S, Brilakis ES, Lennon RJ, Miller ER, Witztum JL, McConnell JP, Kornman KS, Berger PB. Relationship of IgG and IgM autoantibodies to oxidized low density lipoprotein with coronary artery disease and cardiovascular events. J Lipid Res. 2007;48:425-433

68. Wu R, de Faire U, Lemne C, Witztum JL, Frostegard J. Autoantibodies to OxLDL are decreased in individuals with borderline hypertension. Hypertension. 1999;33:53-59

69. Vaarala O, Alfthan G, Jauhiainen M, Leirisalo-Repo M, Aho K, Palosuo T. Crossreaction between antibodies to oxidised low-density lipoprotein and to cardiolipin in systemic lupus erythematosus. Lancet. 1993;341:923-925

70. Swets BP, Brouwer DA, Tervaert JW. Patients with systemic vasculitis have increased levels of autoantibodies against oxidized LDL. Clin Exp Immunol. 2001;124:163-167

71. Slot MC, Theunissen R, van Paassen P, Damoiseaux JG, Cohen Tervaert JW. Anti-oxidized low-density lipoprotein antibodies in myeloperoxidase-positive vasculitis patients preferentially recognize hypochlorite-modified low density lipoproteins. Clin Exp Immunol. 2007;149:257-264

72. Lammie G. Pathology of lacunar infarction. In: Donnan G, Norrving B, Bamford J, Bogousslavsky J, eds. Subcortical Stroke. Oxford: Oxford University Press; 2002:37-46.

73. Boiten J, Lodder J, Kessels F. Two clinically distinct lacunar infarct entities? A hypothesis. Stroke. 1993;24:652-656

74. Boiten J, Lodder J. Risk factors for lacunar infarction. In: Donnan G, Norrving B, Bamford J, Bogousslavsky J, eds. Subcortical Stroke. Oxford: Oxford Unversity Press; 2002:87-97.

75. Cohen Tervaert JW. Translational mini-review series on immunology of vascular disease: accelerated atherosclerosis in vasculitis. Clin Exp Immunol. 2009;156:377-385

76. Wuerfel J, Haertle M, Waiczies H, Tysiak E, Bechmann I, Wernecke KD, Zipp F, Paul F. Perivascular spaces--MRI marker of inflammatory activity in the brain? Brain. 2008;131:2332-2340

77. Walter DH, Rittig K, Bahlmann FH, Kirchmair R, Silver M, Murayama T, Nishimura H, Losordo DW, Asahara T, Isner JM. Statin therapy accelerates reendothelialization: a novel effect involving mobilization and incorporation of bone marrow-derived endothelial progenitor cells. Circulation. 2002;105:3017-3024

78. Werner N, Junk S, Laufs U, Link A, Walenta K, Bohm M, Nickenig G. Intravenous transfusion of endothelial progenitor cells reduces neointima formation after vascular injury. Circ Res. 2003;93:e1724

79. Fujiyama S, Amano K, Uehira K, Yoshida M, Nishiwaki Y, Nozawa Y, Jin D, Takai S, Miyazaki M, Egashira $\mathrm{K}$, Imada T, Iwasaka T, Matsubara H. Bone marrow monocyte lineage cells adhere on injured endothelium in a monocyte chemoattractant protein-1-dependent manner and accelerate reendothelialization as endothelial progenitor cells. Circ Res. 2003;93:980-989

80. Griese DP, Ehsan A, Melo LG, Kong D, Zhang L, Mann MJ, Pratt RE, Mulligan RC, Dzau VJ. Isolation and transplantation of autologous circulating endothelial cells into denuded vessels and prosthetic grafts: implications for cell-based vascular therapy. Circulation. 2003;108:2710-2715

81. Hill JM, Zalos G, Halcox JP, Schenke WH, Waclawiw MA, Quyyumi AA, Finkel T. Circulating endothelial progenitor cells, vascular function, and cardiovascular risk. N Engl J Med. 2003;348:593-600

82. Tao J, Wang Y, Yang Z, Tu C, Xu MG, Wang JM. Circulating endothelial progenitor cell deficiency contributes to impaired arterial elasticity in persons of advancing age. J Hum Hypertens. 2006;20: 490-495

83. Vasa M, Fichtlscherer S, Aicher A, Adler K, Urbich C, Martin H, Zeiher AM, Dimmeler S. Number and migratory activity of circulating endothelial progenitor cells inversely correlate with risk factors for coronary artery disease. Circ Res. 2001;89:E1-7

84. Delva P, Degan M, Vallerio P, Arosio E, Minuz P, Amen G, Di Chio M, Lechi A. Endothelial progenitor cells in patients with essential hypertension. J Hypertens. 2007;25:127-132

85. Oliveras A, Soler MJ, Martinez-Estrada OM, Vazquez S, Marco-Feliu D, Vila JS, Vilaro S, Lloveras J. Endothelial progenitor cells are reduced in refractory hypertension. J Hum Hypertens. 2008;22: 183-190

86. Werner N, Kosiol S, Schiegl T, Ahlers P, Walenta K, Link A, Bohm M, Nickenig G. Circulating endothelial progenitor cells and cardiovascular outcomes. N Engl J Med. 2005;353:999-1007 
87. Ghani U, Shuaib A, Salam A, Nasir A, Shuaib U, Jeerakathil T, Sher F, O'Rourke F, Nasser AM, Schwindt B, Todd K. Endothelial progenitor cells during cerebrovascular disease. Stroke. 2005;36:151-153

88. Taguchi A, Matsuyama T, Moriwaki H, Hayashi T, Hayashida K, Nagatsuka K, Todo K, Mori K, Stern DM, Soma T, Naritomi H. Circulating CD34-positive cells provide an index of cerebrovascular function. Circulation. 2004;109:2972-2975

89. Yip HK, Chang LT, Chang WN, Lu CH, Liou CW, Lan MY, Liu JS, Youssef AA, Chang HW. Level and value of circulating endothelial progenitor cells in patients after acute ischemic stroke. Stroke. 2008;39:69-74

90. Chu K, Jung KH, Lee ST, Park HK, Sinn DI, Kim JM, Kim DH, Kim JH, Kim SJ, Song EC, Kim M, Lee SK, Roh JK. Circulating endothelial progenitor cells as a new marker of endothelial dysfunction or repair in acute stroke. Stroke. 2008;39:1441-1447

91. Sobrino T, Hurtado O, Moro MA, Rodriguez-Yanez M, Castellanos M, Brea D, Moldes O, Blanco M, Arenillas JF, Leira R, Davalos A, Lizasoain I, Castillo J. The increase of circulating endothelial progenitor cells after acute ischemic stroke is associated with good outcome. Stroke. 2007;38:2759-2764

92. Slevin M, Krupinski J, Slowik A, Kumar P, Szczudlik A, Gaffney J. Serial measurement of vascular endothelial growth factor and transforming growth factor-beta1 in serum of patients with acute ischemic stroke. Stroke. 2000;31:1863-1870

93. Bogoslovsky T, Spatz M, Chaudhry A, Maric D, Luby M, Frank J, Warach S. Stromal-derived factor1 [alpha] correlates with circulating endothelial progenitor cells and with acute lesion volume in stroke patients. Stroke. 2011;42:618-625

94. Petit I, Jin D, Rafii S. The SDF-1-CXCR4 signaling pathway: a molecular hub modulating neoangiogenesis. Trends Immunol. 2007;28:299-307

95. Hess DC, Hill WD, Martin-Studdard A, Carroll J, Brailer J, Carothers J. Bone marrow as a source of endothelial cells and NeuN-expressing cells After stroke. Stroke. 2002;33:1362-1368

96. Zhang ZG, Zhang L, Jiang Q, Chopp M. Bone marrow-derived endothelial progenitor cells participate in cerebral neovascularization after focal cerebral ischemia in the adult mouse. Circ Res. 2002;90:284-288

97. Bliss T, Guzman R, Daadi M, Steinberg GK. Cell transplantation therapy for stroke. Stroke. 2007;38: 817-826

98. Galimi F, Summers RG, van Praag H, Verma IM, Gage FH. A role for bone marrow-derived cells in the vasculature of noninjured CNS. Blood. 2005;105:2400-2402

99. Kokaia Z, Lindvall O. Neurogenesis after ischaemic brain insults. Curr Opin Neurobiol. 2003;13:127-132

100. Thored P, Wood J, Arvidsson A, Cammenga J, Kokaia Z, Lindvall O. Long-term neuroblast migration along blood vessels in an area with transient angiogenesis and increased vascularization after stroke. Stroke. 2007;38:3032-3039

101. Gama Sosa MA, De Gasperi R, Rocher AB, Perez GM, Simons K, Cruz DE, Hof PR, Elder GA. Interactions of primary neuroepithelial progenitor and brain endothelial cells: distinct effect on neural progenitor maintenance and differentiation by soluble factors and direct contact. Cell Res. 2007;17:619-626

102. Zhang RL, Zhang ZG, Chopp M. Neurogenesis in the adult ischemic brain: generation, migration, survival, and restorative therapy. Neuroscientist. 2005;11:408-416

103. Hur J, Yang HM, Yoon CH, Lee CS, Park KW, Kim JH, Kim TY, Kim JY, Kang HJ, Chae IH, Oh BH, Park YB, Kim HS. Identification of a novel role of $T$ cells in postnatal vasculogenesis: characterization of endothelial progenitor cell colonies. Circulation. 2007;116:1671-1682

104. Ceradini DJ, Kulkarni AR, Callaghan MJ, Tepper OM, Bastidas N, Kleinman ME, Capla JM, Galiano RD, Levine JP, Gurtner GC. Progenitor cell trafficking is regulated by hypoxic gradients through HIF-1 induction of SDF-1. Nat Med. 2004;10:858-864

105. Staals J, Henskens LH, Delanghe JR, van Oostenbrugge RJ, Kessels AG, Kroon AA, de Leeuw PW, Lodder J. Haptoglobin phenotype correlates with the extent of cerebral deep white matter lesions in hypertensive patients. Curr Neurovasc Res. 2010;7:1-5

106. Staals J, Pieters BMA, Knottnerus ILH, Rouhl RPW, van Oostenbrugge RJ, Delanghe JR, Lodder J. Haptoglobin polymorphism and lacunar stroke. Curr Neurovasc Res. 2008;5:153-158

107. Tseng CF, Lin CC, Huang HY, Liu HC, Mao SJ. Antioxidant role of human haptoglobin. Proteomics. 2004; 4:2221-2228

108. Park SJ, Baek SH, Oh MK, Choi SH, Park EH, Kim NH, Shin JC, Kim IS. Enhancement of angiogenic and vasculogenic potential of endothelial progenitor cells by haptoglobin. FEBS Lett. 2009;583:3235-3240 
109. Whittaker A, Moore JS, Vasa-Nicotera M, Stevens S, Samani NJ. Evidence for genetic regulation of endothelial progenitor cells and their role as biological markers of atherosclerotic susceptibility. Eur Heart J. 2008;29:332-338

110. Xiao $Q$, Ye S, Oberhollenzer F, Mayr A, Jahangiri M, Willeit J, Kiechl S, Xu Q. SDF1 gene variation is associated with circulating SDF1alpha level and endothelial progenitor cell number: the Bruneck Study. PLOS ONE. 2008;3:e4061

111. Pieters B, Staals J, Knottnerus I, Rouhl R, Menheere P, Kessels A, Lodder J. Periventricular white matter lucencies relate to low vitamin B12 levels in patients with small vessel stroke. Stroke. 2009;40: 1623-1626

112. Gianazza E, Veber D, Eberini I, Buccellato FR, Mutti E, Sironi L, Scalabrino G. Cobalamin (vitamin B12)deficiency-induced changes in the proteome of rat cerebrospinal fluid. Biochem J. 2003;374:239-246

113. Lehmann M, Regland B, Blennow K, Gottfries CG. Vitamin B12-B6-folate treatment improves bloodbrain barrier function in patients with hyperhomocysteinaemia and mild cognitive impairment. Dement Geriatr Cogn Disord. 2003;16:145-150

114. Rouhl RPW, Van Oostenbrugge RJ, Damoiseaux JGMC, Debrus-Palmans LL, Delanghe JR, Cohen Tervaert JW, Lodder J. Impaired vitality of endothelial progenitor cells in patients with cerebral small vessel disease: the importance of vitamin B12 and haptoglobin phenotype (Abstract). Cerebrovasc Dis. 2008;25:1-192

115. Rouhl RPW, Van Oostenbrugge RJ, Damoiseaux JGMC, Debrus-Palmans LL, Knottnerus ILH, Staals J, Cohen Tervaert JW, Lodder J. The role of vitamin B12 status in the impaired vitality of endothelial progenitor cells in lacunar stroke patients (Abstract). Cerebrovasc Dis. 2009;27:1-241

116. Rouhl RPW, van Oostenbrugge RJ, Damoiseaux J, Cohen Tervaert JW, Lodder J. Endothelial progenitor cell research in stroke: a potential shift in pathophysiological and therapeutical concepts. Stroke. 2008;39:2158-2165

117. Yemisci M, Gursoy-Ozdemir Y, Vural A, Can A, Topalkara K, Dalkara T. Pericyte contraction induced by oxidative-nitrative stress impairs capillary reflow despite successful opening of an occluded cerebral artery. Nat Med. 2009;15:1031-1037

118. Potter G, Doubal F, Jackson C, Sudlow C, Dennis M, Wardlaw J. Associations of clinical stroke misclassification ('clinical-imaging dissociation') in acute ischemic stroke. Cerebrovasc Dis. 2010;29:395-402

119. Cordonnier C, Potter GM, Jackson CA, Doubal F, Keir S, Sudlow CL, Wardlaw JM, Al-Shahi Salman R. improving interrater agreement about brain microbleeds: development of the Brain Observer MicroBleed Scale (BOMBS). Stroke. 2009;40:94-99

120. Gottesman RF, Coresh J, Catellier DJ, Sharrett AR, Rose KM, Coker LH, Shibata DK, Knopman DS, Jack $\mathrm{CR}$, Mosley TH, Jr. Blood pressure and white-matter disease progression in a biethnic cohort: Atherosclerosis Risk in Communities (ARIC) study. Stroke. 2010;41:3-8

121. Vermeer SE, Longstreth WT, Jr., Koudstaal PJ. Silent brain infarcts: a systematic review. Lancet Neurol. 2007;6:611-619

122. Awad IA, Spetzler RF, Hodak JA, Awad CA, Carey R. Incidental subcortical lesions identified on magnetic resonance imaging in the elderly. I. Correlation with age and cerebrovascular risk factors. Stroke. 1986;17:1084-1089

123. Henskens LH, van Oostenbrugge RJ, Kroon AA, de Leeuw PW, Lodder J. Brain microbleeds are associated with ambulatory blood pressure levels in a hypertensive population. Hypertension. 2008;51:62-68

124. Staals J, van Oostenbrugge RJ, Knottnerus IL, Rouhl RP, Henskens LH, Lodder J. Brain microbleeds relate to higher ambulatory blood pressure levels in first-ever lacunar stroke patients. Stroke. 2009;40:3264-3268

125. Prins ND, van Straaten EC, van Dijk EJ, Simoni $M$, van Schijndel RA, Vrooman HA, Koudstaal PJ, Scheltens $\mathrm{P}$, Breteler MM, Barkhof F. Measuring progression of cerebral white matter lesions on MRI: visual rating and volumetrics. Neurology. 2004;62:1533-1539

126. Jimenez JJ, Jy W, Mauro LM, Soderland C, Horstman LL, Ahn YS. Endothelial cells release phenotypically and quantitatively distinct microparticles in activation and apoptosis. Thromb Res. 2003;109:175-180

127. Barber PA, Foniok T, Kirk D, Buchan AM, Laurent S, Boutry S, Muller RN, Hoyte L, Tomanek B, Tuor UI. MR molecular imaging of early endothelial activation in focal ischemia. Ann Neurol. 2004;56:116-120 
128. Sibson NR, Blamire AM, Bernades-Silva M, Laurent S, Boutry S, Muller RN, Styles P, Anthony DC. MRI detection of early endothelial activation in brain inflammation. Magn Reson Med. 2004;51:248-252

129. Boutry S, Burtea C, Laurent S, Toubeau G, Vander Elst L, Muller RN. Magnetic resonance imaging of inflammation with a specific selectin-targeted contrast agent. Magn Reson Med. 2005;53:800-807

130. Reynolds PR, Larkman DJ, Haskard DO, Hajnal JV, Kennea NL, George AJ, Edwards AD. Detection of vascular expression of E-selectin in vivo with MR imaging. Radiology. 2006;241:469-476

131. McAteer MA, Sibson NR, von Zur Muhlen C, Schneider JE, Lowe AS, Warrick N, Channon KM, Anthony DC, Choudhury RP. In vivo magnetic resonance imaging of acute brain inflammation using microparticles of iron oxide. Nat Med. 2007;13:1253-1258

132. McAteer MA, Schneider JE, Ali ZA, Warrick N, Bursill CA, von zur Muhlen C, Greaves DR, Neubauer S, Channon KM, Choudhury RP. Magnetic resonance imaging of endothelial adhesion molecules in mouse atherosclerosis using dual-targeted microparticles of iron oxide. Arterioscler Thromb Vasc Biol. 2008;28:77-83

133. Kelly KA, Allport JR, Tsourkas A, Shinde-Patil VR, Josephson L, Weissleder R. Detection of vascular adhesion molecule-1 expression using a novel multimodal nanoparticle. Circ Res. 2005;96:327-336

134. Nitkunan A, Charlton RA, Mclntyre DJ, Barrick TR, Howe FA, Markus HS. Diffusion tensor imaging and MR spectroscopy in hypertension and presumed cerebral small vessel disease. Magn Reson Med. 2008;59:528-534

135. Wu YW, Kao HL, Chen MF, Lee BC, Tseng WY, Jeng JS, Tzen KY, Yen RF, Huang PJ, Yang WS. Characterization of plaques using 18F-FDG PET/CT in patients with carotid atherosclerosis and correlation with matrix metalloproteinase-1. J Nucl Med. 2007;48:227-233

136. Ge Y, Zohrabian VM, Grossman RI. Seven-Tesla magnetic resonance imaging: new vision of microvascular abnormalities in multiple sclerosis. Arch Neurol. 2008;65:812-816

137. Poole KE, Loveridge N, Barker PJ, Halsall DJ, Rose C, Reeve J, Warburton EA. Reduced vitamin D in acute stroke. Stroke. 2006;37:243-245

138. Mikirova NA, Belcaro G, Jackson JA, Riordan NH. Vitamin D concentrations, endothelial progenitor cells, and cardiovascular risk factors. Panminerva Med. 2010;52:81-87

139. Yiu YF, Chan YH, Yiu KH, Siu CW, Li SW, Wong LY, Lee SW, Tam S, Wong EW, Cheung BM, Tse HF. Vitamin d deficiency is associated with depletion of circulating endothelial progenitor cells and endothelial dysfunction in patients with type 2 diabetes. J Clin Endocrinol Metab. 2011;96:E830-835

140. Smolders J, Damoiseaux J. Vitamin D as a T-cell modulator in multiple sclerosis. Vitam Horm. 2011;86:401-428

141. Takeda M, Yamashita T, Sasaki N, Nakajima K, Kita T, Shinohara M, Ishida T, Hirata K. Oral administration of an active form of vitamin D3 (calcitriol) decreases atherosclerosis in mice by inducing regulatory $\mathrm{T}$ cells and immature dendritic cells with tolerogenic functions. Arterioscler Thromb Vasc Biol. 2010;30:2495-2503 
Summary 



\section{Summary}

Cerebral small vessel disease (CSVD) is a disease of the small penetrating arterioles in the brain. CSVD causes lacunar infarcts and white matter lesions (WML). CSVD has a high morbidity: it relates to (recurrent) ischemic stroke, cognitive disturbance and decline. Furthermore, patients with extensive CSVD (lacunar stroke patients with $\mathrm{WML}$ ) have a worse prognosis (with regard to morbidity, stroke recurrence, and mortality), also on the long term, as compared to lacunar stroke patients without extensive CSVD (WML). However, the cause of CSVD, and therefore any therapeutic or preventive regimen, remains elusive. One of the current hypotheses is that blood-brain barrier (BBB) dysfunction will ultimately lead to CSVD. Because the BBB comprises the complex interplay between endothelial cells and the surrounding tissue, dysfunction of one of its components could lead to the dysfunction of the entire BBB. The main hypothesis of the research presented in this thesis is that endothelial dysfunction relates to CSVD (Chapter 1). Possible causes of this dysfunction are inflammation (immune activation) and a defective endothelial repair mechanism.

Before examining this hypothesis, we first examined the relation between established radiological manifestations of CSVD (lacunar infarcts and WML) and enlarged Virchow Robin spaces in Chapter 2. Our aim was to extend the spectrum of CSVD with another radiological manifestation, namely the enlarged Virchow Robin spaces. We found in 165 first-ever lacunar stroke patients, that increasing numbers of enlarged Virchow Robin spaces at the level of the basal ganglia related to an increasing extent of WML and (asymptomatic) lacunar infarcts. This suggests that WML and lacunar infarcts share their underlying vascular abnormality (CSVD) with enlarged Virchow Robin spaces.

We then continued with a study in two different patient groups (lacunar stroke patients and essential hypertensive patients) to examine the relation between immune activation, endothelial dysfunction and CSVD. In the first part, we measured antibodies against oxidized forms of LDL, which also relate to another vascular disease: atherosclerosis. In Chapter 3, we studied 158 lacunar stroke patients, 158 essential hypertensive patients and 43 controls. We found that patients with CSVD (as defined by the presence of WML and lacunar infarcts on MR of the brain) had higher levels of (possibly harmful) IgG-antibodies against hypochlorite oxidized LDL as well as lower levels of (possibly protective) IgM-antibodies against malondiadehyde modified LDL than patients without such lesions. Furthermore, we found that higher IgG-antibodies against hypochlorite oxLDL-levels were independently related to higher numbers of our newly found marker of CSVD: Virchow Robin spaces at the level of the basal ganglia. In the second part, we measured markers of endothelial dysfunction and markers of monocyte activation. In Chapter 4, we studied 163 lacunar stroke patients, as well as 183 essential hypertensive patients. We found that levels of neopterin, a 
marker for monocyte activation by T-lymphocytes, as well as markers of endothelial dysfunction (sICAM and SVCAM) were higher in patients with extensive WML and lacunar infarcts. From these two studies we conclude that an immune response, involving activated and dysfunctional endothelium as well as activated monocytes and antibody production, may play a role in CSVD.

The effect of immune activation and endothelial dysfunction on the BBB and the pathogenesis of CSVD might be counteracted by protective mechanisms. Endothelial progenitor cells (EPC) may constitute one such protective mechanism. EPC are immature endothelial cells which circulate in peripheral blood. EPC are may repair damaged endothelium and may attenuate the endothelial dysfunction, which possibly causes CSVD. As EPC research in stroke and cerebrovascular disease is limited, we provided an overview of the potentials and pitfalls of EPC research in stroke and cerebrovascular disease in Chapter 5. We tried to instigate vascular neurologists to participate in EPC research, as EPC could also change pathophysiological concepts and improve clinical treatments in vascular neurology.

In Chapter 6, our aim was to demonstrate a relation between EPC number and vitality and CSVD (WML and multiple lacunar infarcts) in patients with a first-ever lacunar stroke and healthy controls. We also looked for possible regulating factors for EPC function in patient serum and studied the effect of different haptoglobin phenotypes on EPC. Haptoglobin is an acute phase protein, of which one of its three phenotypes, the 1-1, relates to WML and lacunar infarcts. This relation might be via its effect on endothelial biology and EPC. We studied 42 lacunar stroke patients and 18 controls without CSVD. We found that EPC vitality was lower in patients especially in those with WML and/or lacunar infarcts, than in controls. We also found that EPC vitality was inhibited by patient serum, especially by serum of patients with WML and lacunar infarcts, but not by control serum. Patients with haptoglobin 1-1 had lower EPC vitality, and when haptoglobin 1-1 was added to EPC cultures, EPC vitality was lower than with the other haptoglobin phenotypes.

In Chapter 7, our aim was to_demonstrate a relation between EPC number and vitality and another possible regulating factor in EPC function, the angiogenic T-cell. These cells promote the formation of new blood vessels and endothelial repair by directly stimulating the function of EPC. In a study in 32 hypertensive patients with CSVD (WML, lacunar infarcts, microbleeds) and 29 hypertensive patients without CSVD, we found that EPC as well as angiogenic T-cell numbers were lower in hypertensives with CSVD than in those without. The relation between lower angiogenic T-cell numbers and CSVD remained significant after correction for other parameters. From these two studies we conclude that patients with CSVD may have a defective endothelial repair mechanism, which, at least partly, might be due to the haptoglobin phenotype as well as to lower angiogenic T-cell numbers. 
In Chapter 8, the implications and applicability of the main findings are discussed and put into perspective. All studies suggest that the (cerebral) endothelium is involved in CSVD. This involvement probably concerns a process with inflammation and defective endothelial repair. This process might lead to a dysfunction of the blood brain barrier and CSVD. This conclusion however, leaves several questions unanswered, like:

1) Do markers of endothelial activation and inflammation, enlarged Virchow-Robin spaces, and EPC parameters also predict CSVD progression radiologically as well as clinically (mainly in the area of cognitive function)?

2) Are the parameters we measured actually reflecting endothelial activation/dysfunction and/or damage and does this process actually occur in the brain?

3) Is enhancement of the endothelial repair mechanism possible and does this enhancement lead to improvement or attenuation of CSVD?

Suggestions for future research to answer these questions are included in this last chapter. 

Samenvatting 



\section{Samenvatting}

Cerebral Small Vessel Disease (Nederlands: cerebrale kleine vaten ziekte; CSVD) tast de kleine perforerende arteriën in de hersenen aan. Zo veroorzaakt CSVD lacunaire herseninfarcten en witte stof afwijkingen (WSA). CSVD heeft een hoge morbiditeit, aangezien CSVD gerelateerd is aan (herhaaldelijke) herseninfarcten en cognitieve stoornissen en achteruitgang. Patiënten met uitgebreide CSVD (lacunair herseninfarct met WSA) hebben een slechtere prognose (met betrekking tot morbiditeit, recidief herseninfarct en mortaliteit), ook op de lange termijn, dan patiënten zonder uitgebreide CSVD. Echter, de oorzaak van CSVD blijft onduidelijk, en daarom zijn er ook nog steeds geen effectieve therapieën of preventieve maatregelen bekend. Een van de hypothesen betreffende de oorzaak is dat een dysfunctie van de bloed-hersen-barrière uiteindelijk leidt tot CSVD. Aangezien de bloed-hersen-barrière bestaat uit een complex samenspel tussen endotheelcellen en het omgevende weefsel, kan dysfunctie van één van deze componenten leiden tot een dysfunctie van de gehele bloed-hersenbarrière. Daarom is hoofdhypothese van het onderzoek in dit proefschrift dat endotheliale dysfunctie verband houdt met CSVD (Hoofdstuk 1). Mogelijke oorzaken van deze dysfunctie zijn inflammatie (activatie van het immuunsysteem) en een tekortschietend herstelmechanisme van het endotheel.

Alvorens deze hypothese te onderzoeken, trachtten we eerst het radiologisch beeld van CVSD te verbreden door te onderzoeken of er een verband is tussen bekende manifestaties van CSVD, zoals WSA en lacunaire in herseninfarcten en verwijde Virchow Robinse ruimtes. In Hoofdstuk 2 vonden wij, bij 165 patiënten met een eerste lacunair herseninfarct, dat hogere aantallen verwijde Virchow Robinse ruimtes op het niveau van de basale kernen geassocieerd waren met ernstigere WSA en meer lacunaire herseninfarcten. Hieruit kan afgeleid worden dat verwijde Virchow Robinse ruimtes, WSA en lacunaire herseninfarcten een vergelijkbare onderliggende oorzaak, c.q. vaatpathologie, hebben, namelijk CSVD.

Om te onderzoeken of een verband is tussen CSVD, activatie van endotheelcellen en een geactiveerde immuunrespons verzamelden wij twee patiëntengroepen, namelijk patiënten met een lacunair herseninfarct en patiënten met essentiële hypertensie. In het eerste deel, beschreven in Hoofdstuk 3, bestudeerden wij 158 patiënten met een eerste lacunair herseninfarct, 158 patiënten met essentiële hypertensie en 43 controles. Wij onderzochten in deze studie antistoffen tegen verschillende vormen van geoxideerd LDL. Deze antistoffen zijn o.a. ook betrokken bij atherosclerose, een andere vaatziekte. In onze studie vonden wij dat patiënten met CSVD (gedefinieerd als de aanwezigheid van WSA en/of (oude) lacunaire infarcten op de MRI-scan) hogere spiegels hadden van (waarschijnlijk nadelige) IgG-antistoffen tegen hypochloriet geoxideerd LDL, terwijl deze groep lagere spiegels had van (waarschijnlijk voordelige) IgM-antistoffen tegen MDA-gemodificeerd LDL in vergelijking met patiënten zonder 
CSVD. Verder vonden wij dat hogere spiegels van IgG-antistoffen tegen hypochloriet geoxideerd LDL onafhankelijk geassocieerd waren aan onze nieuw gevonden marker van CSVD: verwijde Virchow Robinse ruimtes op het niveau van de basale kernen. In het tweede deel, maten wij merkers van activatie en dysfunctie van van endotheelcellen en van activatie van monocyten. In Hoofdstuk 4, bestudeerden wij 163 patiënten met een lacunair herseninfarct en 183 patiënten met essentiële hypertensie. Wij toonden aan dat spiegels van neopterine, een merker voor activatie van monocyten door T lymfocyten, en merkers van endotheelactivatie (sICAM en sVCAM) hoger waren bij patiënten met WSA en/of (oude) lacunaire infarcten. We concluderen uit deze twee studies dat een immuunrespons, waarbij er enerzijds activatie en dysfunctie van endotheel is, en anderzijds monocytenactivatie en productie van antistoffen is, een rol zou kunnen spelen bij CSVD.

Het effect van activatie van het immuunsysteem en het endotheel op de pathogenese van CSVD zou tegengegaan kunnen worden door beschermingsmechanismen. Endotheliale progenitor cellen (EPC) zouden een beschermend effect kunnen hebben. EPC zijn onrijpe endotheelcellen die in het bloed circuleren. EPC zouden beschadigd endotheel kunnen repareren en zouden zo ook endotheelactivatie en -dysfunctie, de veronderstelde oorzaak van CSVD, kunnen afremmen. Aangezien het EPC-onderzoek bij cerebrovasculaire ziekten en herseninfarcten bijzonder beperkt is, gaven wij in Hoofdstuk 5 een overzicht van de mogelijkheden, onmogelijkheden en valkuilen van EPC-onderzoek bij herseninfarcten en cerebrovasculaire aandoeningen. Hiermee probeerden wij om vasculair neurologen te bewegen om in het EPC-onderzoek te stappen, aangezien EPC binnen de vasculaire neurologie de pathofysiologische concepten zou kunnen veranderen en de behandelingen zou kunnen verbeteren.

In Hoofdstuk 6 was ons doel om een verband aan te tonen tussen EPC aantal en vitaliteit en CSVD (opnieuw gedefinieerd als WSA en (oude) lacunaire herseninfarcten) bij patiënten met een eerste lacunair herseninfarct. In deze studie zochten wij ook naar mogelijke regulerende factoren van de EPC functie in het serum van patiënten. Zo bestudeerden wij het effect van verschillende haptoglobine fenotypes op EPC. Haptoglobine is een acute fase eiwit met verschillende fenotypes, waarvan het 1-1 fenotype geassocieerd is met WSA en lacunaire infarcten. Mogelijk is deze relatie het gevolg van het effect van haptoglobine 1-1 op EPC functie. Wij bestudeerden 42 patiënten met een eerste lacunair herseninfarct en 18 controles zonder CSVD. Wij vonden dat de EPC vitaliteit slechter was bij patiënten met een lacunair herseninfarct, in het bijzonder bij degenen met tevens WSA en (meerdere) oude lacunaire infarcten. Wij toonden tevens aan dat serum van patiënten, in vergelijking met serum van gezonde controles, de vitaliteit van EPC negatief beïnvloedt, met name serum van patiënten met tevens WSA en/of lacunaire infarcten. Verder hadden patiënten met haptoglobine 1-1 een lagere EPC vitaliteit en toevoegen van haptoglobine 1-1 bij EPC kweken leidde tot een lagere vitaliteit dan toevoegen van andere haptoglobine 
fenotypes. In Hoofdstuk 7 was ons doel om een verband aan te tonen tussen EPC aantal en vitaliteit en een andere mogelijk regulerende factor van de EPC functie: de angiogene $\mathrm{T}$ lymfocyt. Angiogene $\mathrm{T}$ cellen stimuleren de vorming van nieuwe bloedvaten en endotheelherstel door een direct effect op EPC. Wij onderzochten 32 patiënten met essentiële hypertensie met CSVD (WSA, lacunaire infarcten en/of microbleeds) en 29 hypertensieven zonder CSVD. Wij vonden dat zowel EPC aantallen als angiogene $T$ cel aantallen lager waren bij patiënten met CSVD in vergelijking met de groep patiënten zonder CSVD. Het verband tussen angiogene T cellen en CSVD bleef significant na statistische correctie voor andere mogelijk beïnvloedende variabelen (zoals bloeddruk en andere vaatziektes). Wij concluderen uit deze twee studies dat patiënten met CSVD wel eens een defect endotheelherstelmechanisme zouden kunnen hebben. Hierbij zouden, in ieder geval ten dele, het haptoglobine fenotype als lagere angiogene $T$ cel aantallen een rol kunnen spelen.

In Hoofdstuk 8 worden de betekenis en toepasbaarheid van de belangrijkste bevindingen uit dit proefschrift bediscussieerd. Alle studies suggereren dat bij CSVD het (cerebrale) endotheel betrokken is in een process met activatie van het immuunsysteem en een tekortschietend endotheel regeneratievermogen. Dit proces leidt mogelijk tot een dysfunctie van de bloed-hersen-barrière en tot CSVD. Deze conclusie laat echter enkele vragen ontbeantwoord, zoals:

1) Zijn de waardes van de merkers van endotheelactivatie en inflammatie, verwijde Virchow Robinse ruimtes en EPC parameters ook voorspellend voor CSVD progressie radiologisch en klinisch (met name cognitief functioneren) over verloop van tijd?

2) Zijn de merkers een adequate afspiegeling van wat zich in het brein afspeelt?

3) Is het mogelijk om de herstelmechanismen (door EPC) te verbeteren en zou een dergelijke verbetering leiden tot een verbetering of remming van CSVD?

Suggesties voor verder onderzoek om deze vragen te beantwoorden worden in dit laatste hoofdstuk gegeven. 

Dankwoord 



\section{Dankwoord}

Het is (bijna) zover! Het boekje is klaar, al zal de wetenschap zelf me misschien nooit(?) meer loslaten. Gedurende het schrijven aan dit boekje zijn er veel dingen gebeurd en vorderde het schrijven het ene moment wat beter dan het andere, niet in het minst door de combinatie met de specialistische opleiding en gezinsuitbreiding. Ik ben blij dat ik terug kan kijken op een periode die mij veel heeft gebracht, waarvoor ik graag een aantal personen wil bedanken.

Allereerst de leden van mijn promotieteam (met een ideale combinatie van voornamen overigens, wat niet zelden tot misverstanden leidde).

Prof. Dr. J. Lodder, beste Jan. Je stond aan de wieg van het LACI-project, de basis van het onderzoek van mijn proefschrift, al zijn die LACl's in mijn proefschrift misschien wat ondergesneeuwd door EPC's, immunologische bepalingen en de groep patiënten met hypertensie. Voor mij was je een constante factor en sturende kracht, al was je het laatste jaar niet meer lijfelijk op de afdeling aanwezig. Je kritische blik en gedachten slepen mijn denkproces. Ik heb zo veel van je geleerd! Mijn PhD krijgt door jouw begeleiding ook zijn ware inhoudelijke betekenis.

Prof. Dr. J.W. Cohen Tervaert, beste Jan Willem. Jij was de sturende kracht tijdens mijn jaren op dat vreemde lab van de immunologie. Je gaf me alle ruimte om nieuwe dingen te doen en stimuleerde zo mijn creatieve labtechnische vermogen, iets waarvan ik in de toekomst nog veel plezier zal hebben.

Prof. Dr. R.J. van Oostenbrugge, beste Robert. Het begon met de subsidieaanvraag die we samen schreven, waardoor ik uiteindelijk twee jaar fulltime aan mijn onderzoek kon besteden. Meer mogelijkheid tot verdieping kon ik mij haast niet wensen. Ik moest in het begin wennen aan je gedachten die telkens twee sprongen overslaan, maar als ik eenmaal op hetzelfde spoor was werkte dit verfrissend snel. Jouw vermogen tot multitasken is echt ongeëvenaard.

Dr. J. Damoiseaux, beste Jan. Officieel mocht je niet bij het promotieteam horen, al is dit alleen al vanuit je mate van betrokkenheid bij het onderzoek onterecht. Ik heb je nooit anders gezien dan als dagelijks begeleider/co-promotor. Je lab-technische expertise, maar vooral je oplossingsgerichte denken zijn een verademing!

Iris Knottnerus en Julie Staals. Zonder jullie was dit boekje er niet gekomen! Wat een werk is het geweest om alle data te verzamelen, ik moet er niet aan denken dat ik dat in mijn eentje had moeten doen. Het waren mooie tijden, met een gereedschapskist als prikkoffer in de trein tussen Sittard en Maastricht, met congresbezoeken helaas meestal in het koele Noord-Europa, en de LACl-club. Iris, ik hoop dat je je onderzoek met verve zult verdedigen, veel succes! Julie, al ligt mijn aandachtsgebied wel inmiddels elders, ik hoop dat we als collega-stafleden dezelfde goede band en samenwerking kunnen houden!

De mensen van het lab: Josien, Petra, Henk, Nele, Maria, José, Joost, Benjamin, Marielle, Steven en Annelien en in het bijzonder Lucienne Debrus-Palmans en Ruud Theunissen. Dank vooral voor de dagelijkse gezelligheid en voor alle vlaai... Ruud: dank 
voor je zeer nauwkeurige bepalingen van de anti-oxLDL-antilichamen en adhesiemoleculen, al je hulp bij het haptoglobine-onderzoek en de carnavalsmuziek. Ik hoop dat je nog lang met plezier kunt blijven werken, ondanks alle perikelen rondom de immunologie in Maastricht. Lucienne: dank voor je hulp bij de cel-gerelateerde labonderzoeken! Heerlijk toch, dat tellen van EPC-clusters of migrerende EPC's onder de microscoop? Ik hoop dat je als echte levensgenietster nog lang kunt genieten van het leven op de manier zoals alleen jij dat kunt!

Dr. L.H.G. Henskens, Dr. A.A. Kroon en Prof.dr. P.W. de Leeuw, beste Léon, Bram en Peter. Onze samenwerking heeft geleid tot mooie resultaten, maar liefst drie hoofstukken, drie publicaties in toonaangevende tijdschriften. Dank voor jullie frisse kijk, jullie hypertensie-bril, en dank voor het ter beschikking stellen van de grote database van de HYBRiD-studie die zulk een belangrijk deel uitmaakt van de resultaten in publicaties. Zonder jullie input had mijn proefschrift niet deze vorm gehad!

De afdeling neurologie in het Orbis Medisch Centrum in Sittard, secretaresses en neurologen. Dank voor jullie bijna vanzelfsprekende medewerking bij het inrichten van een LACI-poli en voor de mogelijkheden tot het includeren van patiënten voor mijn onderzoek. Het is een aanzienlijk aantal en daarom: ook zonder jullie was mijn boekje er niet geweest in de huidige vorm. Dank!

Polimedewerksters van de poli neurologie in Maastricht. Dank voor de ruimte die jullie iedere keer weer vrijmaakten op de poli voor series van bloedafnames. Jullie wisten direct wie te bellen als er weer iemand voor bloedafname voor onderzoek bij de balie stond!

De afdeling klinische neurofysiologie. Dank dat ik gebruik mocht maken van één van jullie kamers voor ochtenden lang bloedafnames voor één van de studies.

Collega-assistenten neurologie en neurologen in Maastricht. Jullie zijn, zonder uitzondering, geweldige mensen. Het doen van onderzoek naast je opleiding is soms zwaar en een fijne werkomgeving met goede collega's en supervisoren maakt dan veel goed. Gelukkig ben ik wat de combinatie opleiding en onderzoek betreft niet de enige en zijn er lotgenoten. Pim, ik heb bewondering voor je manier waarop je alles in je leven weet te combineren en ik vind het stiekem ook leuk dat een gedeelte van mijn onderzoek terugkomt in het jouwe. Ik ben er trots op dat jij vandaag als paranimf mij bij zal staan.

Vrienden! Muziek is wat ons bindt of bond en dat zal zeker niet veranderen. Dank voor jullie spontane interesse in het onderzoek, of juist voor de totale afleiding met feestjes, kwartetten, SSSSSS, oliebollen, Efteling, harmonie of al die andere dingen die we samen doen. Richard: ik ben er trots op dat jij mij als paranimf bij zal staan en ik ben benieuwd of dit aan het WS-gevoel kan tippen!

Mijn familie: schoonouders Materna en Henk, schoonzus Charlene en schone broer Martijn. Dank voor jullie steun en hulp in het leven, en Martijn: dank voor het waarmaken van mijn idee voor de kaft! Zusje Janine en 'zwager' René: vroeger was er een groot leeftijdsverschil tussen ons, maar de laatste tijd wordt het alleen maar kleiner. Ik hoop dat we in de toekomst nog veel dingen samen kunnen delen. Mam, 
dank voor de warme omgeving die pap en jij mij hebben gegeven om me persoonlijk te ontwikkelen, en voor jullie onvoorwaardelijke steun en liefde.

Tot slot: mijn eigen thuis met Joyce en sinds kort met Stan. Joyce, bedankt voor je liefde en warmte, voor je geduld, hulp en adviezen en eigenlijk voor ons hele leven samen. We vullen elkaar perfect aan en ik hoop dat we dat nog ons leven lang kunnen blijven doen. Stan: je merkte er niet veel van, maar jij was naast vertragende uiteindelijk ook een versnellende factor voor mijn schrijfproces. Hoe het toch mogelijk is dat ik in je nu nog korte leventje al zo veel van je ben gaan houden! 



\section{List of publications}





\section{List of publications}

Rouhl RPW, Mertens AECS, van Oostenbrugge RJ, Damoiseaux JGMC, Debrus-Palmans LL, Henskens LHG, Kroon AA, de Leeuw PW, Lodder J, Cohen Tervaert JW. Angiogenic T-cells and putative endothelial progenitor cells in hypertension-related cerebral small vessel disease. Stroke 2012;43:256-258

Knottnerus ILH, Winckers K, ten Cate H, Hackeng T, Lodder J, Rouhl RPW, Staals JEA, Govers J, Bekers O, van Oostenbrugge RJ. Levels of heparin releasable TFPI are increased in first-ever lacunar stroke patients. Neurology 2012, in press.

Knottnerus ILH, Gielen M, Lodder J, Rouhl RPW, Staals J, Vlietinck R, van Oostenbrugge RJ. Estimating the magnitude of genetic factors by calculating the genetic relative risk of stroke in first-ever lacunar stroke patients. PLOS One 2011;6:e21439

Rouhl RPW, Damoiseaux JGMC, Lodder J, Theunissen ROMFIH, Knottnerus ILH, Staals J, Henskens LHG, Kroon AA, de Leeuw PW, Cohen Tervaert JW, van Oostenbrugge RJ. Vascular Inflammation in cerebral small vessel disease. Neurobiology of Aging 2011 Epub ahead of print: doi:10.1016/j.neurobiolaging.2011.04.008

Knottnerus ILH, Gielen M, Lodder J, Rouhl RPW, Staals J, Vlietinck R, van Oostenbrugge RJ. Family history of stroke is an independent risk factor for lacunar stroke subtype with asymptomatic lacunar infarcts at younger ages. Stroke 2011;42:1196-1200

Rouhl RPW, van Oostenbrugge RJ, Theunissen ROMFIH, Knottnerus ILH, Staals J, Henskens LHG, Kroon AA, de Leeuw PW, Lodder J, Cohen Tervaert JW, Damoiseaux JGMC. Autoantibodies against oxidized-LDL in cerebral small vessel disease. Stroke 2010;41:2687-2689

Knottnerus ILH, Govers-Riemslag JW, Hamulyak K, Rouhl RPW, Staals J, Spronk HM, van Oerle R, van Raak EP, Lodder J, ten Cate H, van Oostenbrugge RJ. Endothelial activation in stroke subtypes. Stroke 2010;41:1617-1622

Zhang CE, van Raak EP, Rouhl RPW, Staals J, Knottnerus ILH, van Oostenbrugge RJ. Metabolic syndrome relates to lacunar stroke without white matter lesions: a study in first-ever lacunar stroke patients. Cerebrovascular Diseases 2010;29:503-509

Arends SJ, Rouhl RPW, Damoiseaux J, Cohen Tervaert JW. EUSTAR's statement and recommendations on endothelial precursor cells - putting things into perspect. Annals of Rheumatic Diseases. Published online May 202009. 
Rouhl RPW, van Oostenbrugge RJ, Lodder J. White Matter Lesions: From Present to Future. in: Westland TB, Calton RN (eds). Handbook of White Matter, Structure, Function and Changes. Nova Publishers, New York, 2009.

Staals J, van Oostenbrugge RJ, Knottnerus ILH, Rouhl RPW, Henskens LHG, Lodder J. Brain microbleeds relate to higher ambulatory blood pressure levels in first-ever lacunar stroke patients. Stroke 2009;40:32-64-3268

Rouhl RPW, van Oostenbrugge RJ, Damoiseaux JGMC, Debrus-Palmans LL, Theunissen ROMFIH, Knottnerus ILH, Staals JEA, Delanghe JR, Cohen Tervaert JW, Lodder J. Haptoglobin phenotype may alter endothelial progenitor cell cluster formation in cerebral small vessel disease. Current Neurovascular Research 2009;6(1):32-41

Pieters B, Staals J, Knottnerus I, Rouhl R, Menheere P, Kessels A, Lodder J. Periventricular white matter lucencies relate to low vitamin B12 levels in patients with small vessel stroke. Stroke 2009;40(5):1623-1626

Rouhl RPW, Lodder J. ESPRIT: is aspirin plus dipyridamole superior to aspirin alone in TIA or minor stroke patients? Expert Review of Neurotherapeutics 2008;8(11):16611665

Staals J, Pieters BM, Knottnerus ILH, Rouhl RPW, van Oostenbrugge RJ, Delanghe JR, Lodder J. Haptoglobin polymorphism and lacunar stroke. Current Neurovascular Research 2008;5(3):153-158

Rouhl RPW, van Oostenbrugge RJ, Damoiseaux JGMC, Cohen Tervaert JW, Lodder J. Endothelial progenitor cell research in stroke. A potential shift in pathophysiological and therapeutical concepts. Stroke 2008;39(7):2158-2165

Rouhl RPW, van Oostenbrugge RJ, Knottnerus ILH, Staals JEA, Lodder J. Virchow-Robin spaces relate to cerebral small vessel disease severity. Journal of Neurology 2008;255(5):692-696 


\section{Curriculum vitae}





\section{Curriculum vitae}

Rob Peter Willem Rouhl werd op 28 september 1979 geboren in Kerkrade, Nederland. Hij groeide op in Simpelveld, een dorp in het Limburgse heuvelland, alwaar hij de schoolse en buitenschoolse activiteiten van de plaatselijke kleuterschool (St. Anna) en basisschool (St. Jozef) met plezier volgde. Vervolgens ondernam hij elke schooldag de reis naar het Katholiek Gymnasium Rolduc te Kerkrade, hetgeen uiteindelijk leidde tot een succesvolle afsluiting (cum laude) in 1997. In datzelfde jaar startte hij met zijn studie Geneeskunde aan de Universiteit Maastricht. Gedurende zijn studie (1999) raakte hij reeds betrokken als student-assistent bij het vasculair onderzoek op de afdeling neurologie, onder supervisie van dr. J. Lodder (nu prof.dr. J. Lodder). Hij sloot zijn studie Geneeskunde in 2003 cum laude af en begon als arts-assistent niet in opleiding op de afdeling neurologie in het academisch ziekenhuis Maastricht (nu Maastricht Universitair Medisch Centrum ${ }^{+}$), waarna hij zich vanaf november 2004 neuroloog in opleiding mocht noemen. Voor het huidige promotieonderzoek waren toen al de eerste voorzichtige stappen gezet. De basis werd echter gelegd door de periode van juli 2006 tot en met juni 2008 waarbij hij zijn specialistische opleiding onderbrak om zich fulltime aan het laboratoriumgedeelte van het onderzoek te kunnen wijden op het Laboratorium van de Klinische en Experimentele Immunologie van het azM/MUMC ${ }^{+}$(onder supervisie van prof.dr. J.W. Cohen Tervaert en dr. J. Damoiseaux). Per februari 2012 heeft hij zijn opleiding tot neuroloog afgerond en is hij gestart als neuroloog in het $\mathrm{MUMC}^{+}$met als aandachtsgebied epilepsie. 